\title{
Lithologic Characteristics of Upper Oligocene and Miocene Rocks Drilled at Elk Hills, Kern County, California
}

G E OLOG I CA L S URVEY B ULLETIN 1375

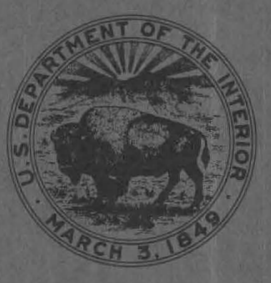





\section{Lithologic Characteristics of \\ Upper Oligocene and Miocene \\ Rocks Drilled at Elk Hills, \\ Kern County, California}

By W. L. ADKISON

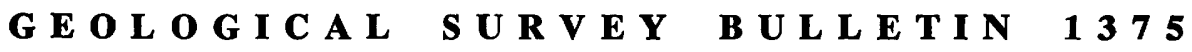

$A$ detailed description of a reference section for the Temblor Formation, Monterey Shale, and Reef Ridge Shale based on well cuttings and cores, foraminiferal determinations, and electrical-log correlations in the western

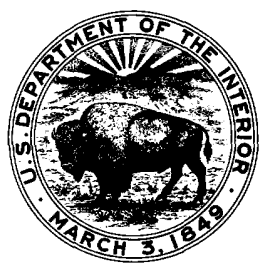
part of the Elk Hills oil field, Naval Petroleum Reserve No. 1 


\section{UNITED STATES DEPARTMENT OF THE INTERIOR}

ROGERS C. B. MORTON, Secretary

\section{GEOLOGICAL SURVEY}

V. E. McKelvey, Director

Library of Congress catalog- card No. 73-600093

For sale by the Superintendent of Documents, U.S. Government Printing Office Washington, D.C. $20402-$ Price $\$ 1.50$ domestic postpaid or $\$ 1.25$ GPO Bookstore Stock Number 2401-00339 


\section{CONTENTS}

\begin{tabular}{|c|c|}
\hline \multirow{2}{*}{\multicolumn{2}{|c|}{ Abstract }} \\
\hline & \\
\hline \multicolumn{2}{|l|}{ 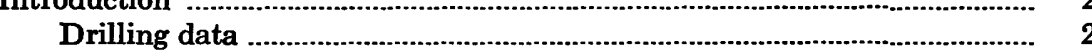 } \\
\hline \multicolumn{2}{|l|}{ Methods of investigation } \\
\hline \multirow{2}{*}{\multicolumn{2}{|c|}{ Stratigraphy _..._. }} \\
\hline & \\
\hline \multirow{2}{*}{\multicolumn{2}{|c|}{$\begin{array}{l}\text { Oligocene and Miocene rocks } \\
\text { Temblor Formation }\end{array}$}} \\
\hline & \\
\hline \multicolumn{2}{|l|}{$\begin{array}{l}\text { Cymric Shale and Wygal Sandstone Members, } \\
\text { undifferentiated }\end{array}$} \\
\hline $\begin{array}{l}\text { undifferentiated } \\
\text { Santos Shale Member }\end{array}$ & \\
\hline Member & \\
\hline Medi & \\
\hline \multicolumn{2}{|l|}{ Miocene rocks .... } \\
\hline Monterey Shale .................... & \\
\hline \multicolumn{2}{|l|}{ Gould Shale Member .............. } \\
\hline Devilwater(?) Shale Member & \\
\hline \\
\hline \multicolumn{2}{|l|}{$\begin{array}{l}\text { McDonald Shale Member of local usage } \\
\text { Elk Hills Shale Member }\end{array}$} \\
\hline \multirow{2}{*}{\multicolumn{2}{|c|}{$\begin{array}{l}\text { Reef Ridge Shale } \\
\text { Post-Miocene rocks }\end{array}$}} \\
\hline & \\
\hline \multicolumn{2}{|l|}{ References cited .... } \\
\hline \multirow{2}{*}{\multicolumn{2}{|c|}{$\begin{array}{l}\text { Detailed description of lithology } \\
\text { Well 526-30R }\end{array}$}} \\
\hline & \\
\hline & \\
\hline & \\
\hline
\end{tabular}

\section{ILLUSTRATIONS}

PLATE 1. Detailed log of Miocene and overlying rocks in NPR-1 Unit well no. 526-30R, sec. 30, T. 30 S., R. 23 E., Elk Hills, Kern County, California

2. Detailed log of upper Oligocene and lower Miocene rocks in NPR-1 Unit well no. 555-30R, sec. 30, T. $30 \mathrm{~S}$.,

R. 23 E., Elk Hills, Kern County, California

FIGURE 1. Map of California showing location of Elk Hills oil field

2. Map showing location of wells $526-30 R$ and $555-30 R$, Elk Hills oil field, Kern County, Calif. in relation to structure of the Etchegoin Formation

3. Map showing location of Elk Hills in relation to most localities of Oligocene and Miocene rocks discussed 


\section{TABLES}

TABLE 1. Foraminifera in cores from the Temblor Formation

Page

in well $555-30 R$

2. Foraminifera in rotary samples from Miocene rocks in well $526-30 R$

3. Porosity and permeability of cores from the Carneros

Sandstone Member of the Temblor Formation

in well 555-30R 


\title{
LITHOLOGIC CHARACTERISTICS OF UPPER OLIGOCENE AND MIOCENE ROCKS DRILLED AT ELK HILLS, KERN COUNTY, CALIFORNIA
}

\author{
By W. L. AdKISON
}

\section{ABSTRACT}

Rocks of late Oligocene and Miocene ages are described in detail for two wells in the western part of the Elk Hills oil field, Naval Petroleum Reserve No. 1, Kern County, Calif. The wells are identified as Unit Operation, Naval Petroleum Reserve No. 1 wells 526-30R and 555-30R, both in sec. 30, T. 30 S., R. 23 E. A reference section for upper Oligocene and Miocene rocks at Elk Hills is established from the detailed descriptions of cuttings and cores, foraminiferal determinations, and electrical-log correlations. The rocks are divided, in upward order, into the Temblor Formation, Monterey Shale, and Reef Ridge Shale. Moderate to steeply dipping strata were encountered in both wells, which were stopped in the Temblor.

Rocks of the Temblor Formation have a drilled thickness of 3,801 feet in well 555-30R and are divided, in upward order, into the Santos Shale, Carneros Sandstone, and Media Shale Members. The Santos Shale Member has a drilled thickness of 3,295 feet in this well and consists of shale, siltstone, and some sandstone. The lower 236 feet is Zemorrian in age and is assigned to the late Oligocene. The upper 220 feet of the Santos in well 555-30R is stratigraphically equivalent to the lower part of the Carneros Sandstone Member in well 526-30R. The Carneros in well 526-30R consists of three bodies of sandstone separated by two beds of shale. The lower sandstone probably grades laterally into siltstone that is included in the upper part of the Santos in well 555-30R. The Media Shale Member at the top of the Temblor is hard shale in well 555-30R, where it has a drilled thickness of 205 feet. In well 526-30R the Media apparently is missing; the Carneros Sandstone Member is unconformably overlain by the Gould Shale Member of the Monterey Shale.

Rocks of the Monterey Shale have a drilled thickness of 4,108 feet in well 526-30R. The members include, in upward order, the Gould, Devilwater(?), McDonald of local usage, and Elk Hills Shale Members. Identification of the members is based largely on the contained Foraminifera. The Gould Shale Member consists of 185 feet of shale. The Devilwater(?) Shale Member, 161 feet thick, is composed of shale, sandstone, and siltstone. The McDonald Shale Member of local usage is 257 feet thick and is almost entirely shale. The Elk Hills Shale Member is a new name proposed herein for strata called Antelope Shale Member in some previous reports on the Elk Hills oil field. The type section for this new member is in well 526-30R, between drilled depths of 6,035 and 9,540 feet, where the rocks are siliceous shale, diatomaceous(?) siltstone, and some sandstone. 
The Reef Ridge Shale consists largely of shale; it has a drilled thickness of 578 feet in well 526-30R. The boundary of the Reef Ridge and the overlying Etchegoin Formation, of Pliocene age, is difficult to determine; the contact may be gradational.

The post-Miocene rocks include, in upward order, the Etchegoin, San Joaquin, and Tulare Formations; these rocks are 5,457 feet in total drilled thickness.

\section{INTRODUCTION}

The Elk Hills oil field lies about 20 miles southwest of the city of Bakersfield in the southern part of the San Joaquin Valley (fig. 1). This giant field constitutes most of Naval Petroleum Reserve No. 1 and extends over much of a large anticline that is expressed on the surface by a line of hills about 17 miles long and 7 miles wide. The field has produced more than 275 million barrels of oil and has ultimate recoverable reserves estimated to exceed 1 billion barrels. The U.S. Government, through the U.S. Navy, owns about 80 percent of the reserves, Standard Oil Company of California the remainder.

This report is part of a comprehensive geologic study of Naval Petroleum Reserve No. 1 made by the U.S. Geological Survey at the request of the Naval Petroleum and Oil Shale Reserves Office of the U.S. Navy. The purpose of the report is to establish and document a reference section for subsurface upper Oligocene and Miocene rocks in the Elk Hills oil field in particular and in the southwestern San Joaquin Valley in general by relating detailed lithologic composition and fossil content to electrical-log characteristics. This detailed study should prove useful not only in the stratigraphic analysis of the Elk Hills oil field but also in the continuing search for oil and gas in the southwestern San Joaquin Valley.

Subsurface reference sections for the Temblor Formation, Monterey Shale, and Reef Ridge Shale are here established in parts of two wells drilled with rotary tools in the western part of the Elk Hills oil field. These wells are identified as Unit Operation Naval Petroleum Reserve No. 1 wells $526-30 \mathrm{R}$ and 555-30R, both located in sec. 30 , T. 30 S., R. 23 E. (fig. 2). Well 555-30R, completed in 1952, is designated a reference section for the Temblor Formation because it contains the most complete section of these rocks and many cores were taken. Well 526-30R, completed in 1968, is designated a reference section for the Monterey Shale and Reef Ridge Shale because the rotary samples of these rocks, taken at 10-foot intervals in this well, are more representative than the samples from well 555-30R. Samples and cores for wells 526-30R and 555-30R are stored in the Navy facilities at Elk Hills.

\section{DRILLING DATA}

Well 555-30R is located 2,381 feet north and 2,239 feet west of the southeast corner of sec. 30, T. 30 S., R. 23 E., Kern County. Drilling 
started on August 26, 1950. Total depth of 12,856 feet was reached on November 21, 1951, and the well was shut in on January 14, 1952. Elevation of the derrick floor, from which depth measurements were made, was 1,341 feet above mean sea level. Dipmeter surveys indicated dips as steep as $60^{\circ}$ in parts of the Temblor Formation. The greatest well-bore deviation, $10^{\circ}$, was found at the total depth. The well was plugged back to 9,385 feet and completed through perforations between 9,309 and 9,350 feet in the First Carneros sand in the upper part of the Temblor Formation. The well flowed 183 barrels of $50.2^{\circ}$

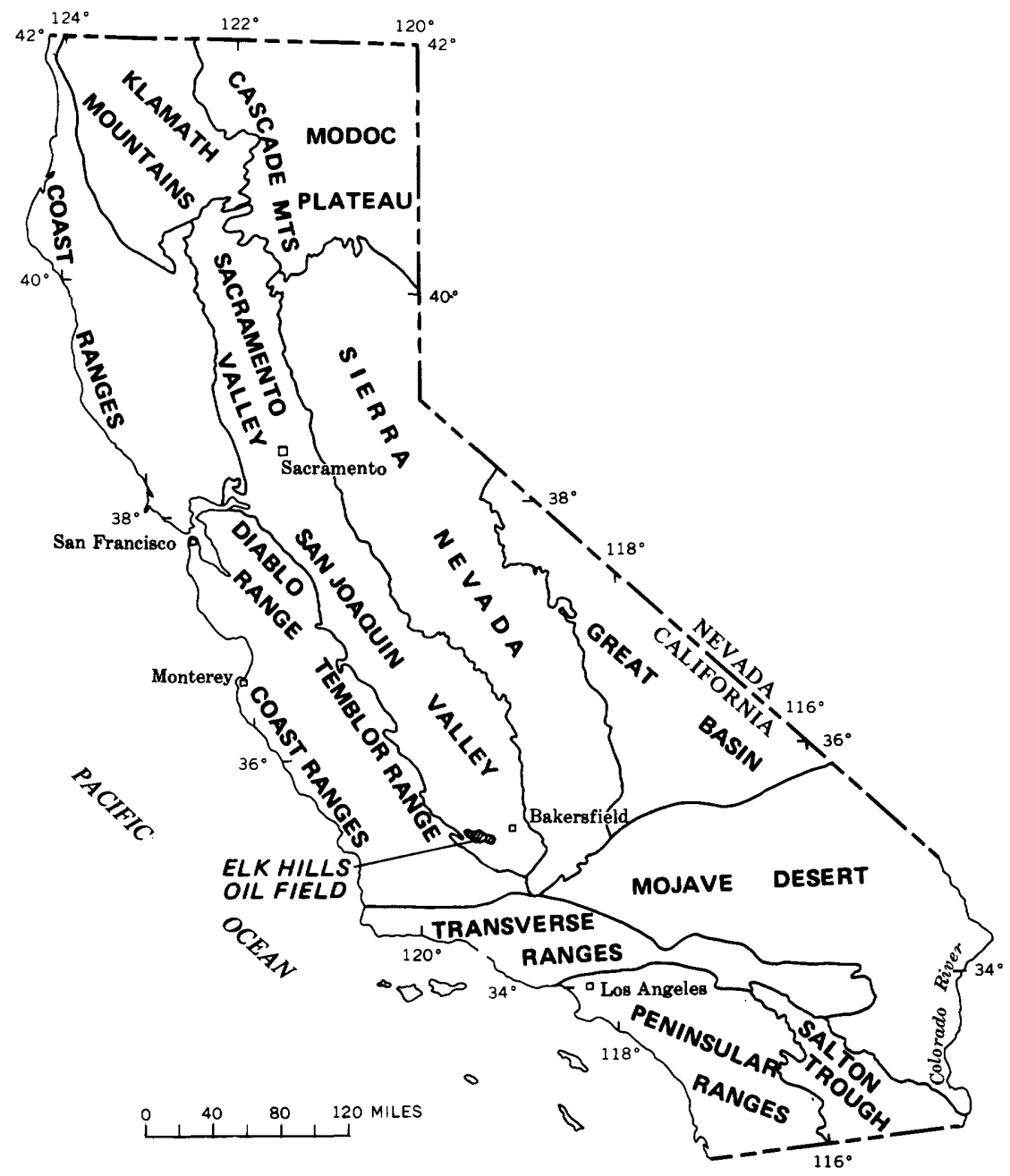

FIGURE 1.-Map of California showing location of Elk Hills oil field. 
$\begin{array}{ll}\text { R. } 22 \text { E. R.23 E. } & \text { R. } 24 \mathrm{E} \text {. }\end{array}$

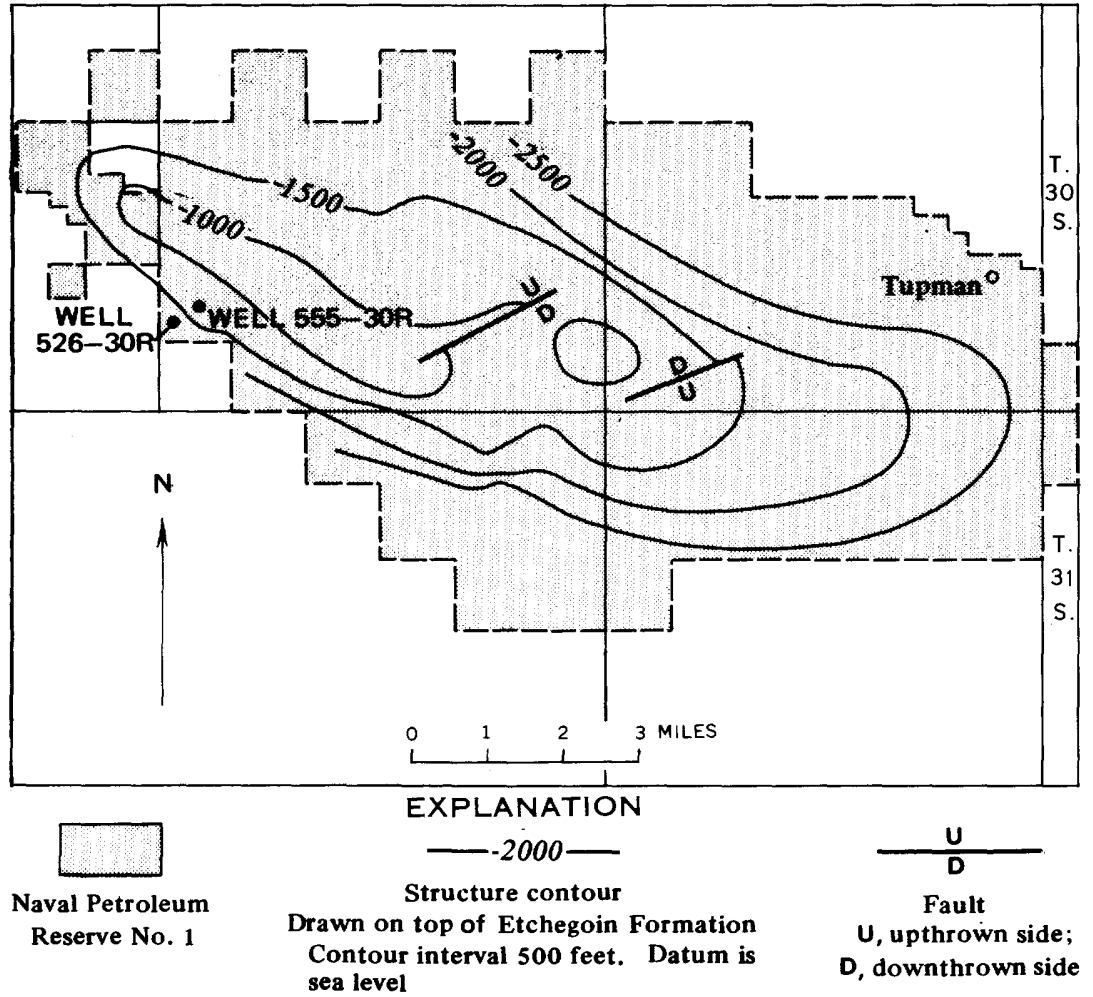

Figure 2.-Location of wells 526-30R and 555-30R, Elk Hills oil field, Kern County, Calif., in relation to structure of the Etchegoin Formation.

gravity (A.P.I.) oil and 1.7 million cubic feet of gas per day through an 11/64-inch choke. An earlier drill-stem test indicated gas in commercial volumes in the Olig sand near the base of the Pliocene Etchegoin Formation.

Well 526-30R is located 1,650 feet north and 990 feet east of the southwest corner of sec. 30, T. 30 S., R. 23 E. Drilling commenced on February 29, 1968, and terminated on May 23, 1968, after reaching a total depth of 10,700 feet. Elevation of the derrick floor, the datum for depth measurements, was 1,261 feet above mean sea level; ground level is 1,245 feet. Dips exceeding $50^{\circ}$ are found in the lower part of the well. Deviation of the well bore reached $25^{\circ}$ in the middle part of the Monterey Shale. Well 526-30R was plugged as a suspended well after an unsuccessful drill-stem test of the Carneros Sandstone Member of the Temblor Formation. An oil-saturated sand is present near the base of the Tulare Formation of Pliocene and Pleistocene age; a production test was not made. 


\section{METHODS OF INVESTIGATION}

Rotary samples and sidewall cores from well 526-30R were examined under a binocular microscope with concurrent reference to the electrical log, using the procedure described by Maher (1959). In addition, the drilling-time log, the driller's daily reports, and the log prepared by the mud loggers were consulted. As the samples were studied, an interpretive sample log was plotted on a paper log strip. Colored pencils were used to designate different rock types, details of lithology were indicated by inked symbols, and rock descriptions were lettered along the side of the log at appropriate depths. The colored strip log was plotted at a scale of 1 inch equals 100 feet; a scale used which permits the showing of beds as thin as 1-2 feet. Conversion to single-color lithologic symbols (pl. 1) required some exaggeration of bed thicknesses or generalization of lithology. For example, many carbonate beds are probably no more than a foot thick, although they are shown considerably thicker.

Rotary samples and conventional cores from well 555-30R (pl. 2) were described by E. E. Glick; he used techniques similar to those used by the writer. Some of the lithologic terminology used by Glick was slightly modified so that it would be consistent with the lithologic terminology used for well 526-30R. Before the sample examination for well 555-30R was started, some cores were sawed parallel to the long axes in order to study bedding features. Half of each sawed core was preserved. The remaining halves of the cores and the cores that could not be sawed were then put through a jaw-type rock crusher to facilitate examination with a binocular microscope. The crushing produced rock fragments slightly larger than average rotary cuttings.

Magnifications of $6.3 \times$ and $10.5 \times$ were used by the writer to examine the gross features of the samples; magnifications as much as $45 \times$ were used to see the minute features. Bedding, except for laminations, is generally not determinable from rotary samples. The Rock Color Chart (Goddard and others, 1948) was used to describe the rock colors. The grain-size terminology is mainly in accordance with the Wentworth grade scale. The term "shale" is used for clastic rocks composed chiefly of clay and fine-silt particles without regard to bedding because clay and fine silt cannot be differentiated with the techniques used in this study. The term "siltstone" is used for clastic rocks composed of coarse-silt particles and also for rocks that probably are composed mainly of medium silt-size diatom fragments and called diatomite by some writers. Limestone was differentiated from dolomite by the speed of reaction in $6 \mathrm{~N}$ hydrochloric acid at room temperature. Dolomite shows no immediate reaction in the acid and dissolves very slowly compared with limestone. All carbonate rocks that were examined contain appreciable but unmeasured amounts of 
silt and clay; this insoluble material may exceed 50 percent of the rock in some beds. The term "dense" is used to describe carbonates and chert composed of particles too small to be seen under $6.3 \times$ magnification. The dense rocks commonly break with a conchoidal fracture. Dark-gray or black rounded grains, probably phosphatic, are generally called by the acronym "sporbo" by local petroleum geologists, and this term is used in some lithologic descriptions.

\section{ACKNOWLEDGMENTS}

Samples and crushed cores from well 555-30R were studied by E. E. Glick, and sawed cores were examined for bedding features by W. A. McCracken. Microfossil determinations were made by R. S. Beck and James Burrow. Core descriptions and other information from the Unit Operator, Standard Oil Company of California, were used where necessary. Stratigraphic correlations are adapted from work by J. C. Maher, R. J. Lantz, and R. D. Carter, of the U.S. Geological Survey, who are conducting a study of the subsurface rocks of the Elk Hills for the U.S. Navy.

\section{STRATIGRAPHY}

Rocks of Cenozoic age are exposed at many places on the flanks of the San Joaquin Valley, where they have been uplifted by major structural movements. Rocks cropping out along the west side of the southern San Joaquin Valley are mostly marine in origin and range in age from Eocene to Pleistocene. Their areal distribution and general structural attitude are shown on geologic maps of the Temblor Range that were compiled by Dibblee $(1968 ; 1973)$. The Cenozoic rocks dip eastward from the 'Temblor Range, extend under the valley, and reappear 50 miles to the east on the flanks of the Sierra Nevada and Tehachapi Mountains. Church and others (1957) have illustrated the regional stratigraphic relations of the Cenozoic rocks by a correlation section that extends from the San Andreas fault on the west side of the Temblor Range, eastward through the Elk Hills oil field, and from there northeastward to the Sierra Nevada foothills northeast of Bakersfield.

The oldest rocks drilled in the western part of Elk Hills at the time of this report (1971) are Eocene and Oligocene in age (J. C. Maher, R. D. Carter, and R. J. Lantz, written commun., 1969). These strata were reached in well 532-25Z, located about a mile west-northwest of well 526-30R and outside the boundary of Naval Petroleum Reserve No. 1. The oldest rocks drilled within the Reserve, found in well 55530R, are assigned an Oligocene age in accordance with Dibblee's (1973) study of equivalent rocks that are exposed in the Temblor Range to the west. Most petroleum geologists have considered these 
rocks to be early Miocene in age. The Oligocene strata are overlain by rocks of Miocene, Pliocene, and Pleistocene age.

\section{OLIGOCENE AND MIOCENE ROCKS}

Rocks of Oligocene and Miocene age crop out in the foothills and mountains west of the San Joaquin Valley and extend eastward beneath younger rocks in the valley. Because these rocks have great economic importance, many geologists have studied them at exposures and in the subsurface for several decades. As a result, the geologic literature contains an abundance of papers that describe or interpret parts of the geologic record in the valley and adjacent areas. Numerous controversies regarding age and correlation have arisen because of rapid and pronounced changes in the lithology, thickness, and faunal content of these rocks. Early workers relied extensively on paleontology in their stratigraphic studies, and later workers found that micropaleontology was very useful, especially in the study of subsurface rocks. These strata are commonly divided by micropaleontologists into stages and zones based on foraminiferal assemblages.

The Oligocene and Miocene rocks in the western part of Elk Hills are divided, in upward order, into the Temblor Formation, Monterey Shale, and Reef Ridge Shale. The Temblor and Monterey are subdivided into members.

\section{TEMBLOR FORMATION}

The name "Temblor Beds" was suggested by Anderson in 1905 (p. 169, 170) for a sequence of sandstone and shale, about 1,500 feet thick, below the Monterey Shale at Canara [Carneros] Springs and at Temblor [Ranch] in western Kern County (fig. 3). During the preceding year Hamlin (1904, p. 14) coined the term "Vaquero Sandstone" for exposures in Los Vaqueros Valley in the western part of Salinas Valley, and in the years following several geologists applied the name "Vaqueros" to Anderson's (1905) Temblor Beds in the San Joaquin Valley and adjacent areas. Anderson (1908, p. 16-20, 38, 39) further described the Temblor Beds, corrected misidentifications of these and other rocks in the area north of Coalinga, and criticized usage of the name "Vaqueros" in the valley and adjacent areas. According to Anderson (1908, p. 38, 39), the original description of the Vaqueros was inadequate both stratigraphically and paleontologically, although he noted that "most of the strata that have been described under the name "Vaquero Sandstone' *** are without doubt to be correlated with the Temblor beds of the Mount Diablo range."

Arnold (1909, p. 19) correlated Anderson's (1905) Temblor Beds in the Coalinga area with his Vaqueros Formation on the basis of paleontologic evidence; he used the name "Vaqueros" and assigned these strata to the lower Miocene. For the next 20 years or more the term "Vaqueros Sandstone" or "Vaqueros Formation" was used in 


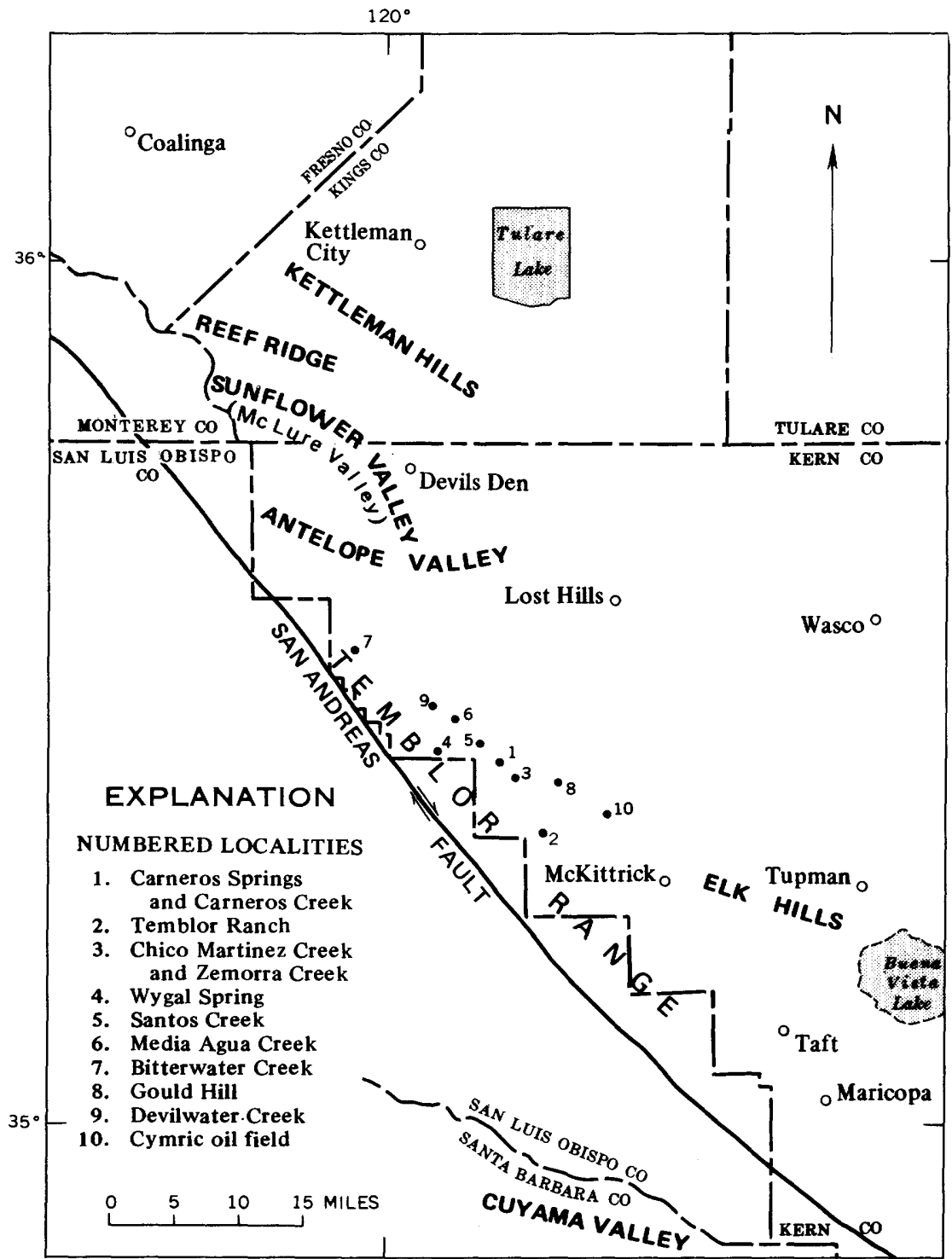

Frgure 3.-Location of Elk Hills in relation to most localities of Oligocene and Miocene rocks discussed.

reports of the U.S. Geological Survey for the San Joaquin Valley and adjacent areas. During most of this period, writers continued to discuss the stratigraphic and chronologic relations between the Vaqueros Sandstone and Temblor Formation, and historical summaries of the controversy are included in articles by Louderback (1913), Wiedey (1928), and Loel and Corey (1932). Wiedey (1928, 
p. 106) believed that the Vaqueros was older than the Temblor and stratigraphically below it. The term "Temblor" has been widely used in the San Joaquin Valley for about 40 years, although some geologists have assigned a Vaqueros age to the lower part of the Temblor Formation. For example, at Kettleman Hills Goudkoff $(1934$, p. 460) provisionally identified the Vaqueros Sandstone beneath the Temblor, although he had no direct paleontologic data to support this identification. The next year Schenck (1935, p. 523) wrote "widely realized to-day is the fact that the lower part of the Temblor formation *** at its type area, is the age equivalent of the upper part of the Vaqueros at its type locality." Woodring, Stewart, and Richards (1940, fig. 14) indicated that the lower part of the Temblor in the Chico Martinez Creek area is equivalent to rocks assigned to the Vaqueros in the south end of the San Joaquin Valley.

The age of the Temblor Formation was first determined as lower (early) Miocene by Anderson (1905, p. 172). Arnold and Anderson $(1910$, p. 87,88$)$ also assigned the Temblor (Vaqueros) in the Coalinga area to the lower Miocene. According to Merriam (1915, fig. 2, p. 26), a vertebrate fossil zone at the top of the Temblor north of Coalinga, the Merychippus zone, is not older than middle Miocene. The Merychippus zone was correlated with part of the Valvulineria californica zone (stratigraphically above the uppermost Temblor in the type area) by Bode $(1935$, p. 84$)$, who concluded that the Merychippus zone cannot be older than late middle Miocene. Schenck (1935, p. 521-536) questioned the assignment of a Miocene age to the Vaqueros Sandstone, the upper part of which is generally considered the age equivalent of the lower part of the Temblor and he concluded that the Vaqueros is probably Oligocene in age. The Temblor Formation was assigned to the lower Miocene and lowermost middle Miocene Series by Kleinpell (1938, fig. 14), who indicated that the lower Miocene of California was supposedly equivalent to part of the Oligocene Series in Europe. According to Foss and Blaisdell (1968, p. 33, 38-41), most geologists assign a Miocene age to the Temblor Formation on the west side of the San Joaquin Valley. The lower part of the Temblor (Zemorrian Stage of Kleinpell, 1938) was considered as mostly or entirely Oligocene in age by Bandy and Arnal $(1969$, p. 793,794$)$. This age designation was used by Dibblee (1973) and it is used in the present report.

The original description of the Temblor Beds by F. M. Anderson $(1905$, p. 169, 170) was very generalized, and a type section was not clearly designated. A few years later, Anderson used the term "type locality" in referring to his earlier description (Anderson, 1908, p. 18), but whether he meant Carneros (Canara) Springs or Temblor Ranch is uncertain. Dibblee (1973) designated (1) the type section of the 
Temblor Formation as that exposed at Carneros Creek, (2) the type area as the exposures from Carneros Creek to Zemorra Creek, and (3) a reference section of the Temblor and all its members as the section exposed at Zemorra Creek (sec. 9, T. 29 S., R. 20 E.) (fig. 3). The lower part of the Temblor Formation on Zemorra Creek, 380 feet thick, was designated the type section of the Zemorrian Stage by Kleinpell (1938, p. 103-108).

The Temblor Formation is commonly divided into members on the northeast flank of the central Temblor Range and in many oil fields to the east. This subdivision resulted from work by petroleum geologists, mainly during the late twenties and early thirties, but by present-day standards, the members were not properly named and defined.

Early descriptions of the Temblor Formation in the vicinity of Carneros and Chico Martinez Creeks were mostly very generalized. More detailed descriptions were published by Kleinpell $(1938, \mathrm{p}$. 105-106), Woodring, Stewart, and Richards (1940, p. 130), Curran (1943, p. 1367-1370), and the San Joaquin Geological Society (1959, p. 13). Foss and Blaisdell (1968, p. 38-41) briefly discussed the lithology, fauna, age, and stratigraphic relations of the members of the Temblor along the west side of the San Joaquin Valley and in the subsurface to the east.

The subdivisions of the Temblor as defined by Dibblee (1973) are used in the present report. The members include, in upward order, the Cymric Shale, Wygal Sandstone, Santos Shale, Agua Sandstone, Carneros Sandstone, Media Shale, and Buttonbed Sandstone. The nomenclature used above, with the exception of two new names, the Cymric and Wygal, closely parallels that of Foss and Blaisdell (1968, p. 38-41).

In the Elk Hills oil field, the Temblor Formation has a drilled thickness of 3,801 feet in well 555-30R. The true thickness is considerably less, but difficult to calculate, because dipmeter surveys show that the rocks dip $22^{\circ}-60^{\circ}$ and the well-bore deviation reaches $10^{\circ}$ at the bottom of the well. The true thickness is probably of the order of 2,400-2,700 feet.

CYMRIC SHALE AND WYGAL SANDSTONE MEMBERS, UNDIFFERENTIATED

The lowermost part of the Temblor Formation, for many years called the Salt Creek Shale Member by petroleum geologists, was renamed the Cymric Shale Member by Dibblee (1973). The new name, taken from the Cymric oil field located mainly in T. 29 S., R. 21 E., (fig. 3) is necessary because the name "Salt Creek" is preoccupied. As early as 1936 the term "Salt Creek Shale" was in common usage in the North Belridge oil field (Williams, 1936, p. 12). The lowermost part of the Temblor on Zemorra Creek was called the Lower Temblor Shale Member by Kleinpell (1938, p. 106) and considered as 
the basal unit of the type Zemorrian Stage. These strata were termed the barren shale member of local usage by Woodring, Stewart, and Richards (1940, p. 130). According to Dibblee (1973), the Cymric Shale Member on Zemorra Creek consists of dark-gray clayey to silty shale about 74 feet thick.

The lower sandstone member of the Temblor Formation has been informally called the Phacoides sand or Phacoides reef for many years. This unit was renamed the Wygal Sandstone Member by Dibblee (1973) because the term "Phacoides," the name of a fossil, may not be used as a stratigraphic term. The new name is taken from Wygal Spring, located in the northeast quarter of sec. 33, T. 28 S., R. 19 E. (fig. 3). As early as 1933, the term "Phacoides reef" was shown on a correlation chart by Gester and Galloway (1933, fig. 3) but was not mentioned elsewhere in their report. Other writers have applied the names "Lower Temblor Sandstone Member" (Kleinpell, 1938, p. 106-108) or " 'Phacoides' reef member of local usage" (Woodring and others, 1940, p. 130) to strata now called Wygal Sandstone Member. This member on Zemorra Creek (fig. 3), about 75 feet thick, consists of gray sandstone that is glauconitic in the upper part and locally fossiliferous and calcareous in the basal part (Dibblee, 1973).

The Cymric Shale and Wygal Sandstone Members were not reached in wells $526-30 \mathrm{R}$ and 555-30R but were drilled in well 53225Z, about a mile to the west-northwest (J. C. Maher, R. D. Carter, and R. J. Lantz, written commun., 1969). Well samples were not available for well 532-25Z, but lithologic interpretation of the electrical $\log$ for this well suggests that these members are composed of shale, siltstone, and thin beds of sandstone and have a total thickness of 257 feet (J. C. Maher, R. D. Carter, and R. J. Lantz, written commun., 1969).

SANTOS SHALE MEMBER

The stratigraphic position of the Santos Shale Member was first indicated in a report on Kettleman Hills by Gester and Galloway (1933, fig. 3), but these writers made no further reference to the Santos. The member presumably was named for exposures on Santos Creek (fig. 3), although this was never formally stated (Heikkila and MacLeod, 1951, p. 8). Sandstone in the upper part of the Santos in the area northwestward from Carneros Creek was called the Agua Sandstone Member, presumably from Media Agua Creek, by Clark and Clark (1935) but they did not adequately define the unit nor specify a type locality. On Zemorra Creek, Kleinpell (1938, p. 106) used the name "Middle Temblor Shale Member," indicated its equivalency to the Santos, and placed the upper limit of the type Zemorrian Stage at the top of a 30-foot sandstone bed that lies 50 feet below the Carneros Sandstone Member. The terms "Lower Santos" and "Upper Santos" were used by Goudkoff (1941, p. 251) for beds below 
and above the Agua Sandstone Member, respectively, and this usage has been widely adopted by petroleum geologists.

The Santos Shale Member, as described by Dibblee (1973), consists of medium- to dark-gray clayey to silty shale that is locally somewhat siliceous in the upper part. The member is 275 feet thick at the reference section on Zemorra Creek, where it is divided into a lower and an upper part, 180 and 60 feet thick respectively, by the Agua Sandstone Member. On the northeast flank of the Temblor Range, the Agua crops out locally as discontinuous lenses of lightgray rarely fossiliferous sandstone, 130 feet thick, within the Santos Shale Member (Dibblee, 1973).

At Elk Hills the Santos Shale Member was reached in both wells described in this report. Well 555-30R (pl. 2) made the greatest penetration into the member, 3,295 feet, but did not reach the base. The Santos in this well is informally divided into six lithologic zones for the purpose of description. The Agua Sandstone Member cannot be identified in well 555-30R. The uppermost (sixth) zone of the Santos in well $555-30 \mathrm{R}$ is stratigraphically equivalent to the lower part of the Carneros Sandstone Member in well 526-30R.

The true thickness of the Santos drilled in well 555-30R is considerably less than the drilled thickness of 3,295 feet. Dipmeter surveys made at numerous points in the member suggest dips of $22^{\circ}-60^{\circ}$, and the direction of dip seemingly varies rather widely. The accuracy of the dipmeter data is unknown. Apparent dips in many cores from the Santos were measured by the Unit Operator. The apparent dips range from $20^{\circ}$ to $80^{\circ}$ and average about $45^{\circ}$. The deviation of the well bore is about $2^{\circ}-5^{\circ}$ through most of the member, but in the lower part the deviation increases to $10^{\circ}$ at the bottom. of the hole. The true thickness of the Santos cannot be determined accurately but probably is about 2,000-2,300 feet. The thicknesses given in this paper for the lithologic zones of the Santos in well 555-30R are drilled thicknesses and are not corrected for dip.

The first or lowermost zone of the Santos consists of medium darkgray to brown shale 236 feet thick. Some beds are limy, silty, or phosphatic, and slickenside surfaces are fairly common in the rotary samples. A thin bed of very silty gray dolomite lies near the middle of the zone. The rotary samples of the rocks were mostly unwashed and dirty and thus difficult to study.

The microfauna in two cores from the lowermost zone of the Santos was studied by R. S. Beck (written commun., 1952). In the upper core (pl. 2) Beck found a few foraminifers that he considered diagnostic of the Zemorrian Stage. These were identified as Siphogenerina nodifera and Siphogenerina cf. S. mayi. Other Foraminifera in the upper core are given in table 1 . The lower core contained undiagnostic 
TABLE 1.-Foraminifera in cores from the Temblor Formation in well 555-30R [Identifications by R. S. Beck]

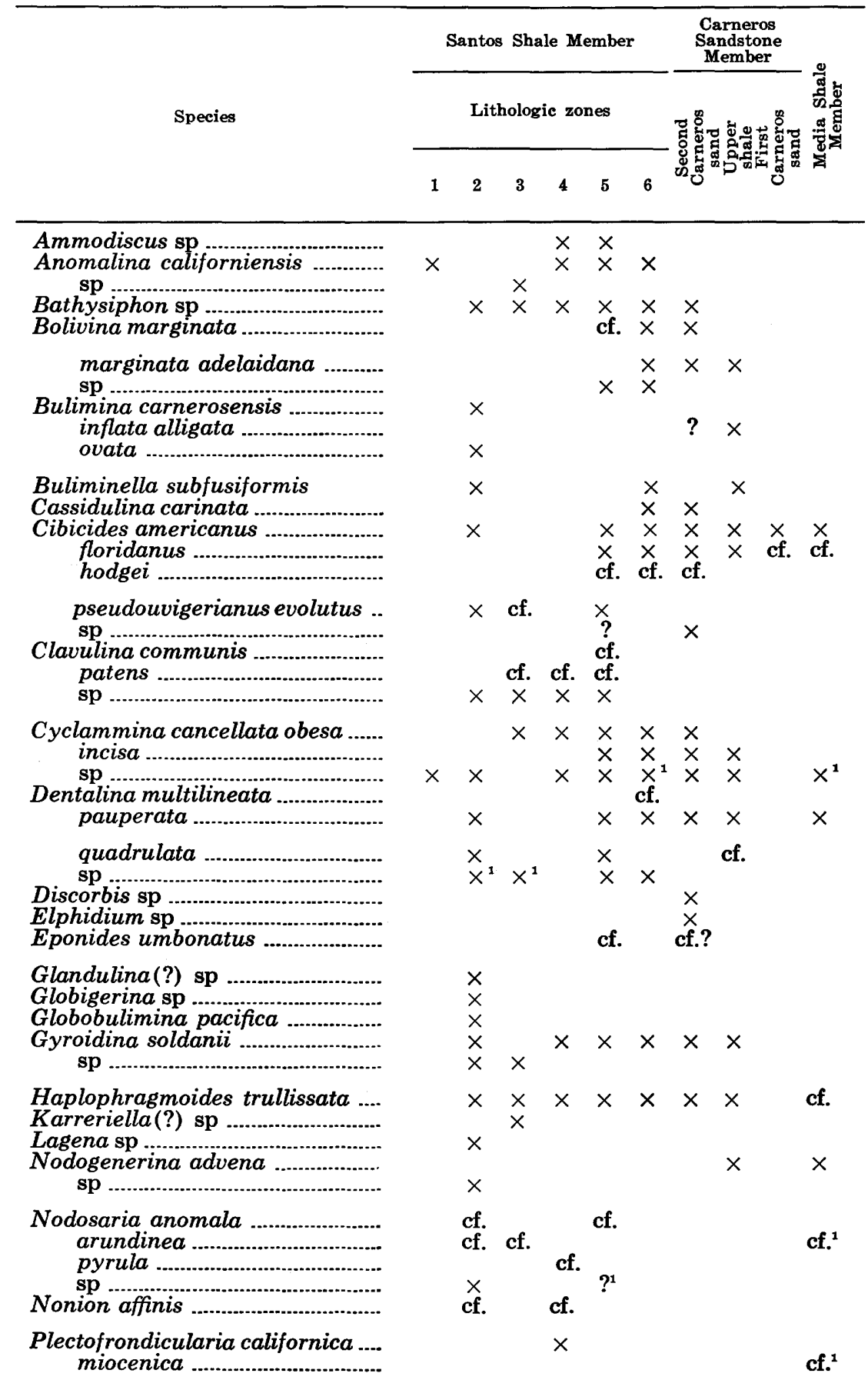


TABLE 1.-Foraminifera in cores from the Temblor Formation in well 555-30R-Continued

\begin{tabular}{|c|c|c|c|c|c|c|c|c|c|c|}
\hline \multirow{3}{*}{ Species } & \multicolumn{6}{|c|}{ Santos Shale Member } & \multicolumn{3}{|c|}{$\begin{array}{l}\text { Carneros } \\
\text { Sandstone } \\
\text { Member }\end{array}$} & \multirow{3}{*}{ - ฮّँّ } \\
\hline & \multicolumn{6}{|c|}{ Lithologic zones } & \multirow{2}{*}{\multicolumn{3}{|c|}{ 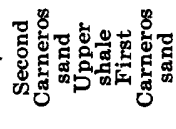 }} & \\
\hline & 1 & 2 & 3 & 4 & 5 & 6 & & & & \\
\hline $\begin{array}{l}\text { Pseudoglandulina conica } \\
\text { Quinqueloculina sp } \\
\text { Robulus simplex } \\
\quad \text { warmani }\end{array}$ & $x$ & $x^{1}$ & $?^{1}$ & cf. $^{1}$ & $\begin{array}{l}\times \\
\times \\
x\end{array}$ & $x$ & $\begin{array}{l}x \\
x \\
x \\
x\end{array}$ & $\begin{array}{l}\times \\
\times \\
\times\end{array}$ & & cf. \\
\hline $\begin{array}{l}\text { Sigmoilina sp ... } \\
\text { Siphogenerina mayi } \\
\quad \text { nodifera } \\
\text { tenua } \\
\text { transversa }\end{array}$ & $\begin{array}{l}\text { cf. } \\
\times \\
\times\end{array}$ & $x$ & $x$ & $x$ & $x$ & $x$ & $x$ & $x$ & cf. ${ }^{1}$ & $\times$ \\
\hline 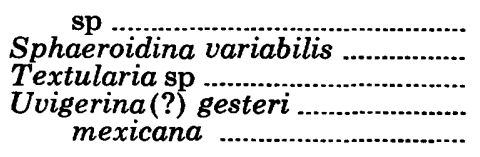 & & $\begin{array}{l}\times \\
\text { cf. } \\
\text { cf. }\end{array}$ & $\times$ & $\stackrel{?^{1}}{\times}$ & $\begin{array}{l}\times \\
? \\
\times\end{array}$ & $\times$ & & & & \\
\hline $\begin{array}{l}\text { Uvigerinella obesa } \\
\quad \text { obesa impolita } \\
\text { californica parva }\end{array}$ & & $\times$ & & & $\times$ & $\underset{x}{x}$ & $\times$ & $\begin{array}{l}\times \\
\times\end{array}$ & & $\times$ \\
\hline Valvulineria nuttalli & & cf. & & & $x^{1}$ & $x$ & $x$ & & $x$ & \\
\hline $\begin{array}{l}\text { Verneuilina(?) sp } \\
\text { Virgulina (?) sp }\end{array}$ & & $x$ & & $x$ & & & & & & \\
\hline
\end{tabular}

${ }^{1}$ Identified from fragments.

arenaceous Foraminifera, pyritized Radiolaria, and fragments of fish bones. Both cores contained plant fragments, according to the core description by the Unit Operator. The lowermost zone of the Santos in well $555-30 \mathrm{R}$ is Zemorrian in age, on the basis of a relatively sparse microfauna, and the zone is assigned a late Oligocene age following Dibblee (1973).

The upper contact of the lowermost zone is marked by an upward change from gray shale to dark-brown siliceous shale. The change in lithology is poorly defined by the electrical properties of the rocks (pl. 2), and the contact may be gradational. This contact probably marks the top of Oligocene strata because, as described below, rocks about 20 feet above the contact contain a sparse microfauna of early Saucesian (early Miocene) age.

The second zone of the Santos, 577 feet thick, is light- to mediumgray siltstone and interbedded medium- to dark-gray silty shale. Some siltstone in the upper part is pale yellowish brown, and some shale in the middle part is dark brownish gray. The siltstone beds are 
partly limy or sandy, and a few are slightly phosphatic. Several shale beds in the lower part contain phosphatic grains in small concentrations. Shale at the base is dark brown, silty, siliceous, hard, and partly fractured. Glauconite is found chiefly in shale in the upper-middle part. A crushed core sample from a depth of about 12,175 feet included some medium-light-gray soft flaky material questionably identified as bentonite. Volcanic glass was identified at a depth of about 12,192 feet.

Fossils in the second zone consist of plant fragments, mainly in the upper part, and scarce microfossils, chiefly Foraminifera. A core near the base of the second zone (pl. 2) contained the foraminifers Siphogenerina tenua and Bulimina carnerosensis, species that R. S. Beck (written commun., 1952) considers diagnostic of the lower Saucesian Stage of early Miocene age.

The upper contact of the second zone is placed at the top of the dominantly siltstone sequence. The contact is probably gradational. The electrical log (pl. 2) indicates no significant differences in electrical properties of the rocks adjacent to the contact.

The third zone, 436 feet thick, is mainly dark-gray shale, but medium-light-gray siltstone and sandstone are interbedded with the shale to a considerable extent in much of the upper half. Grain size of the sandstone varies from very fine to coarse, and the relative abundance of dark-colored grains gives the sandstone a "salt and pepper" appearance. Some shale is silty and slightly phosphatic. Slickenside surfaces were noted in the lower part of the zone, and contorted laminae are present in some siltstone beds in the upperpart.

The rocks of the third zone are largely unfossiliferous except for scarce Foraminifera, given in table 1. A small amount of coalified plant debris was seen in siltstone in the upper part.

The contact with the overlying fourth zone may be an erosional disconformity, for it is marked by an upward change from shale to partly coarse-grained sandstone. This lithologic change apparently coincides with a relatively pronounced change in the electrical resistivity (pl. 2), but the spontaneous-potential curve gives almost no indication of the change in lithology.

The fourth zone of the Santos, 884 feet thick, consists mainly of sandstone in the lower and upper parts and interbedded shale, siltstone, and sandstone in the middle part. Sandstone in the lower 255 feet is medium light gray, very fine to coarse grained, limy, silty, and clayey. The grain size generally decreases upward. Glauconite, phosphatic grains, and mica are found in much of the sandstone, and a "salt and pepper" appearance is fairly common. Sandstone in the rest of the fourth zone resembles that in the lower part except that much of it in the upper part is cemented by dolomite. The generally 
poor sorting of much of the sandstone, indicated by the large variety in grain size and the abundance of silt and clay, suggests low porosity. Siltstone in the fourth zone closely resembles that in the underlying zones. Much of it is sandy, and some in the upper part is very dolomitic. The shale also is very similar to that in underlying zones. Dark shades of gray predominate, but some shale is brownish gray to brownish black. Almost all the shale is silty. The upper half of this zone contains a few beds of light-gray to brownish-gray dense silty dolomite, possibly only a few inches thick. Slickenside surfaces were noted on shale fragments in parts of the interval between 10,956 and about 11,143 feet, and some contorted bedding was seen in core samples taken between 11,143 and 11,151 feet.

Twenty-one core samples from the fourth zone were tested for permeability; the maximum permeability, 1 millidarcy, was at a depth of $11,219.5$ feet. The porosity of these samples was not determined. Slight oil stains in two cores were noted by the Unit Operator (pl. 2).

Plant fossils are present in some beds in the middle and upper parts of the fourth zone, and fish scales are in a few beds, mainly near the top. Foraminifera are generally rare; the species identified are given in table 1 . In several cores the foraminifers were fragmented and (or) arenaceous and could not be identified.

Rocks of the fourth zone include much sandstone and seem to lie in the stratigraphic position of the Agua Sandstone Member; this member forms the uppermost part of the Zemorrian Stage at exposures on Zemorra Creek (Dibblee, 1973, fig. 11). This correlation is not supported by foraminiferal identifications. According to R. S. Beck (written communs., 1952, 1969), cores from the fourth zone contained no Foraminifera definitely indicative of a Zemorrian age, whereas the core near the base of the older second zone contained Siphogenerina tenua and Bulimina carnerosensis, species diagnostic of an early Saucesian age.

The contact with the overlying fifth zone appears to be marked by an upward change from sandstone to dolomite. The contact could not be identified on the electrical log.

The fifth zone of the Santos Shale Member consists mainly of silty shale 942 feet thick. The shale is commonly medium dark gray, but some in the lower part is dark brownish gray. Much of the shale is hard and at least slightly limy. The zone includes many thin beds and laminae of gray siltstone and, in the lower and middle parts, a few beds of medium-light-gray silty glauconitic fine-grained sandstone. Most rocks include at least some phosphatic material, especially in the lower part and also near the top. The lower and middle parts contain a few beds of impure dolomite; fractures are present in the two lower beds. Some shale fragments from the lower part have slickenside 
surfaces. Contorted bedding in siltstone and shale was noted in a few samples about 290 feet above the base and also near the top of the zone.

A core sample of sandstone from a depth of 10,229.5 feet had a porosity of 4.2 percent and no permeability. Fractures in the sandstone and the underlying thin shale contained oil, according to the Unit Operator.

Generally, rocks of the fifth zone become increasingly fossiliferous upward. Fossils consist mainly of Foraminifera, given in table 1, and fish scales and bone fragments. Near the top a few beds contain scarce pelecypods informally termed "mud pectens." Plant fragments are conspicuously absent. Many of the rocks may be diatomaceous, but diatoms were not definitely recognized. These rocks rather closely resemble some of the diatomaceous rocks of the upper Miocene.

The upper contact of the fifth zone of the Santos in well 555-30R lies in an interval of missing well samples. Electrical properties of the strata in this interval suggest an upward change from shale to siltstone at the contact (pl. 2). The siltstone probably grades westward into sandstone that, in well 526-30R (pl. 1), was called the Third Carneros sand of the Carneros Sandstone Member (R. D. Carter, J. C. Maher, and R. J. Lantz, written commun., 1969). Because rocks in the stratigraphic position of the Third Carneros sand seemingly include no sandstone in well 555-30R, the top of the Santos Shale Member is placed stratigraphically higher at the base of sandstone locally called the Second Carneros sand (pl. 2).

The sixth (uppermost) zone of the Santos Shale Member in well $555-30 \mathrm{R}$ is composed of silty shale and interbedded siltstone. These rocks, 220 feet thick, are stratigraphically equivalent to the lower part of the Carneros Sandstone Member, but they are assigned to the Santos because of the almost total absence of sandstone. The shale is mostly medium dark gray to brownish black, limy, phosphatic, and relatively hard. Siliceous shale is present in the upper part. The medium-light-gray siltstone closely resembles that in the underlying zones of the Santos. Most of the siltstone probably occurs as very thin beds and laminae that grade upward into shale beds of similar thickness. Two thin beds of medium-light-gray silty bentonite are present about 35 feet below the top of the zone. Slickenside surfaces were noted in the bentonite.

Numerous beds in the sixth zone contain Foraminifera, given in table 1, and fish scales and bone fragments. Diatoms were questionably identified in a few beds, and some beds may be composed largely of diatom fragments.

The top of the sixth zone is marked by a sharp upward change from shale to sandstone. This lithologic change is clearly indicated by the 
spontaneous-potential curve of the electrical log (pl. 2), although the depth to the contact, if determined from this curve, is several feet less than the depth recorded by the driller. At a depth of 9,672 feet, the driller measured and corrected the depth to 9,663 feet. Driller's depths were used in the preparation of plate 2 , and the depth correction was not distributed upward from the point of measurement.

Well 526-30R was drilled 256 feet into the Santos Shale Member, and two sidewall cores were taken (pl. 1). The strata are equivalent to the upper part of the fifth zone of the member in well 555-30R. According to dipmeter surveys, the Santos in well 526-30R probably dips about $30^{\circ}-60^{\circ}$ toward the northeast, and the well bore through this member deviates $4^{\circ}-5^{\circ}$ toward the west-southwest.

The Santos in well 526-30R consists of shale, a few thin beds of dolomite, and two thin beds of sandstone. The shale is dark shades of gray and brownish gray, silty or limy, and slightly to moderately siliceous in parts. A thin bed of light-gray flaky shale seemingly lies 100 feet above the bottom of the hole, but this material in the samples may have caved from above. The dolomite is dark brownish gray, very fine grained, hard, and very silty; one bed is finely sandy. White crystalline dolomite or calcite fills fractures in the dolomite. The thickness of the dolomite beds is difficult to determine. The sandstone is light to medium gray, very fine to fine grained, silty, and slightly limy and glauconitic. The upper bed is siliceous, and both beds appear to have little porosity.

Foraminifera are the principal fossils found in the Santos in well 526-30R, but a few fragments of fish bones in some samples from the lower 100 feet were noted by R. S. Beck (written commun., 1969). The Foraminifera are given in table 2 and some are shown with the $\log$ on plate 1 . The stratigraphic positions of the microfossils indicated on plate 1 are approximate because only rotary samples were used. Portions of samples from three consecutively drilled 10-foot intervals were combined to make one paleontologic sample representing a 30foot interval. The microfauna suggests an early Saucesian (early Miocene) age, according to R. S. Beck (written commun., 1969).

The upper contact of the Santos Member in well 526-30R is defined by an upward change from shale to sandstone. This contact is probably sharp. It is readily recognizable on the spontaneous-potential curve of the electrical log but is less well defined on the short-normal resistivity curve (pl. 1).

\section{CARNEROS SANDSTONE MEMBER}

The term "Carneros Sandstone" was shown as a subdivision of the Temblor Formation by Goudkoff (1931, table 1). Cushman and Barbat (1932, footnote on p. 31) state that Carneros Sandstone Member was a name used by H. G. Schenck "*** for the prominent 
TABLE 2.-Foraminifera in rotary samples from Miocene rocks in well 526-30R [Identifications by R. S. Beck]

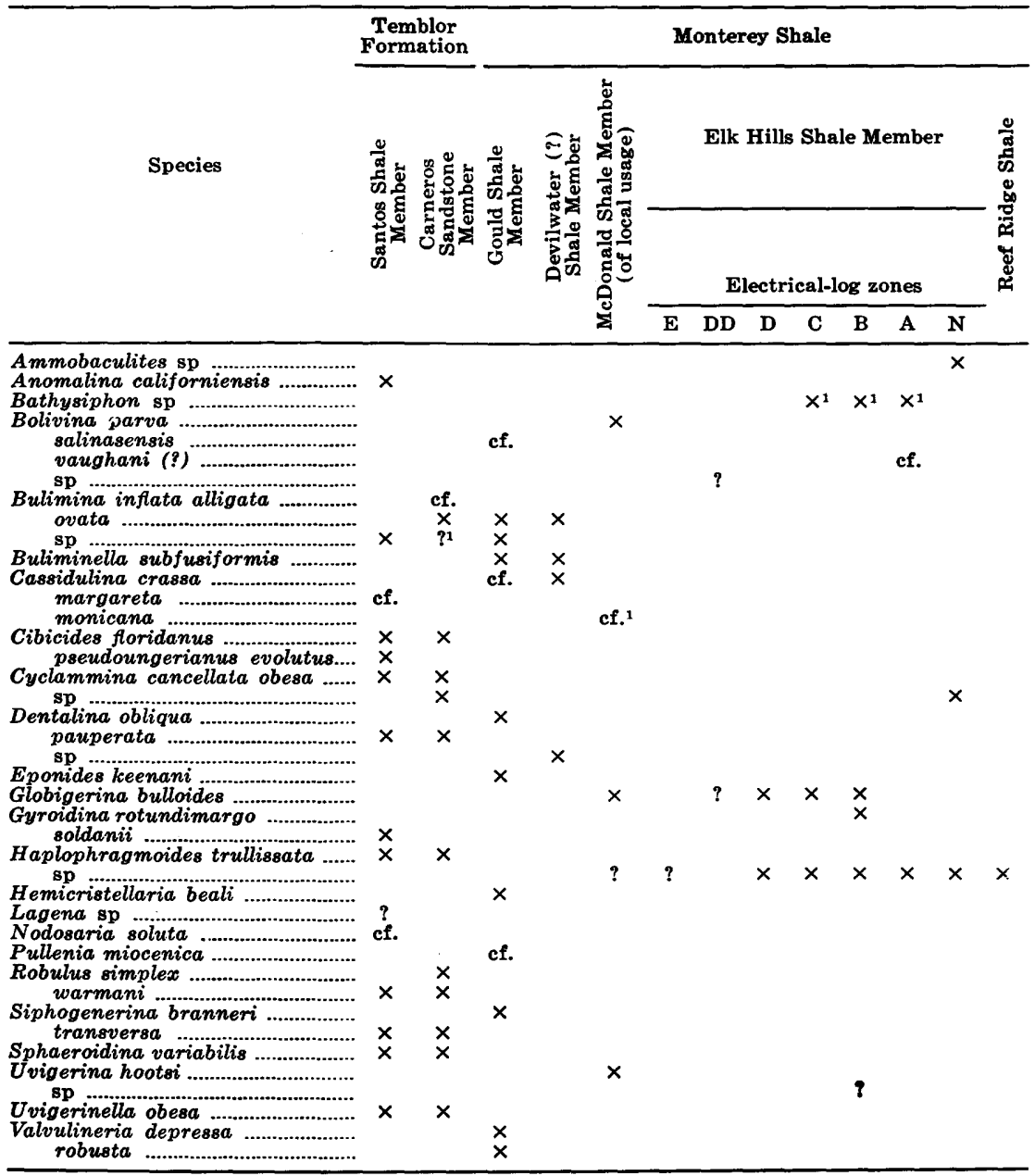

'Identified from fragments.

sandstone containing Pecten miguelensis Arnold near the middle of the Type Temblor section." This member on Zemorra Creek (fig. 3) consists of medium- to coarse-grained sandstone, 215 feet thick, that contains many zones of hard limy concretions; a thin foraminiferal shale lies 80 feet below the top (Woodring and others, 1940, p. 130). Heikkila and MacLeod (1951, p. 9) described facies changes in the Bitterwater Creek area, northwestern Kern County, where sandstone of the Carneros grades laterally into shale assigned to the upper part of the Santos Shale Member and the Media Shale Member.

The Carneros Sandstone Member in the western part of the Elk Hills oil field and adjacent areas includes a considerable amount of 
shale that, for the most part, lies in two laterally persistent unnamed zones. Although these shale zones commonly include some interbedded sandstone and siltstone, they provide the basis for locally differentiating three bodies of sandstone, informally named, in downward order, the First, Second, and Third Carneros sands (R. J. Lantz and R. D. Carter, written commun., 1969). As described, the Third Carneros sand probably grades into siltstone between wells 526-30R and 555-30R. The siltstone equivalent of the Third Carneros sand and the overlying shale zone in well $555-30 \mathrm{R}$ are included in the Santos Shale Member.

The Carneros Sandstone Member in well 526-30R has a drilled thickness of 301 feet. Dipmeter surveys indicate that, in general, the rocks dip $25^{\circ}-40^{\circ}$ toward the northeast, and the deviation of the well bore through the member is $3^{\circ}-5^{\circ}$, mostly westward. The true thickness may approximate 250 feet. Drilled thicknesses are used in the following description.

The Third Carneros sand of the Carneros Sandstone Member is 14 feet thick in well 526-30R, where it consists of light-gray sandstone (pl. 1). The sandstone is very fine to medium grained, silty, partly limy, and glauconitic. Coarse grains are scattered in the lower part; the grain size of the sandstone probably decreases upward. A bed of medium-gray shale, about a foot thick, lies near the middle of the Third Carneros sand.

Microfossils may be present in the Third Carneros sand, but none were seen when the samples were examined. Foraminifera from the Carneros Sandstone Member are given in table 2. The occurrence of Foraminifera in the different parts of the member is not shown in table 2, mainly because caving and contamination of samples is possible in rotary drilling.

The Third Carneros sand is overlain by the lower shale of the Carneros Sandstone Member in well 526-30R. The curves of the electrical $\log (\mathrm{pl} .1)$ suggest a relatively sharp contact.

The lower shale of the Carneros Sandstone Member, 187 feet thick, consists mostly of medium- to dark-gray and dark-brownish-gray shale. Some shale beds are silty, slightly limy, or siliceous. Two thin beds of bentonitic(?) shale are found in the middle and upper parts respectively. The bed in the middle part has a conspicuous light-gray color and a waxy luster. The positions of these two beds are apparently marked on the electrical log by uncommonly low resistivity at depths of 10,285 and 10,340 feet (pl. 1). These beds probably are useful local stratigraphic markers in the western part of the Elk Hills oil field and adjacent areas, as suggested by electrical-log correlations from well 555-30R northwestward to the Railroad Gap oil field (R. J. Lantz and R. D. Carter, written commun., 1969). Another thin bed 
of bentonitic(?) shale may lie near the base of the lower shale at a depth of 10,410 feet, but this is uncertain. The lower shale of the Carneros also includes, in the lower-middle part, a 4-foot bed of finegrained gray siliceous sandstone and an overlying bed of darkbrownish-gray hard impure dolomite.

Fossils in the lower shale of the Carneros consist of Foraminifera, and these are included in table 2. The microfaunal assemblage is indicative of a Saucesian age (R. S. Beck, written commun., 1969).

The upper contact of the lower shale is defined by an upward change from very siliceous shale to sandstone. The contact is probably sharp, though on the spontaneous-potential curve of the electrical log it is only moderately well defined (pl. 1).

The description of the rest of the Carneros Sandstone Member is chiefly for well 555-30R, because the member was cored almost completely in that well. Core recovery was poor to fair for many intervals, but for the member as a whole, recovery was nearly 72 percent.

The Carneros Sandstone Member in well 555-30R includes, in upward order, the Second Carneros sand, the upper shale, and the First Carneros sand (pl. 2). The drilled thickness, 301 feet, considerably exceeds the true thickness, for three dipmeter surveys indicate dips of $25^{\circ}-48^{\circ}$ in the member. Many apparent dips measured in cores and reported by the Unit Operator range from $30^{\circ}$ to $60^{\circ}$ and average about $43^{\circ}$. Wellbore deviation was $3^{\circ}-4^{\circ}$ through the member. The true thickness may be as little as 220 feet or as much as 260 feet. Drilled thicknesses are given in the following description.

The Second Carneros sand of the Carneros Sandstone Member, 158 feet thick in well 555-30R, consists of sandstone in the lower half and interbedded sandstone and shale in the upper half. The sandstone is medium light gray to brownish gray, mostly very fine to medium grained, limy or dolomitic, silty, and clayey. Some sandstone contains coarse or very coarse grains. Glauconite is found as scattered grains mainly in the lower part. Laminae of shale and siltstone are common in most of the sandstone. Shale in the Second Carneros is medium dark gray to brownish black, silty, and slightly limy and phosphatic. The color is generally darker in the upper part. Because contorted bedding is a common feature, sediment flowage in a relatively plastic state may have occurred shortly after deposition of much of the strata.

Porosity and permeability of the sandstone in the Second Carneros sand were determined in 1951 during the drilling of the well. Core sampling was done at 1-foot intervals for the most part. The porosity ranges from 6.9 percent to 19.9 percent, as shown in table 3 , and generally exceeds 10 percent. Permeability of the sandstone ranges from 0 to 17 millidarcys, but only a few samples had permeability greater 
TABLE 3.-Porosity and permeability of cores from the Carneros Sandstone Member of the Temblor Formation in well 555-30R

[Determinations by Core Laboratories, Inc.]

\begin{tabular}{|c|c|c|c|c|c|c|c|c|}
\hline $\begin{array}{l}\text { Depth } \\
\text { (feet) }\end{array}$ & $\begin{array}{l}\text { Permeability } \\
\text { (millidarcys) }\end{array}$ & $\begin{array}{c}\text { Porosity } \\
\text { (percent) }\end{array}$ & $\begin{array}{l}\text { Depth } \\
\text { (feet) }\end{array}$ & $\begin{array}{l}\text { Permeability } \\
\text { (millidarcys) }\end{array}$ & $\begin{array}{c}\text { Porosity } \\
\text { (percent) }\end{array}$ & $\begin{array}{l}\text { Depth } \\
\text { (feet) }\end{array}$ & $\begin{array}{l}\text { Permeability } \\
\text { (millidarcys) }\end{array}$ & $\begin{array}{c}\text { Porosity } \\
\text { (percent) }\end{array}$ \\
\hline \multicolumn{9}{|c|}{ First Carneros sand } \\
\hline $\begin{array}{l}9279.5 \\
9280.5 \\
9281.5 \\
9289.5 \\
9290.5 \\
9291.5 \\
9292.5 \\
9293.5 \\
9294.5 \\
9295.5 \\
9296.5 \\
9297.5 \\
9298.5 \\
9299.5 \\
9303.5 \\
9305.5 \\
9306.5 \\
\end{array}$ & $\begin{array}{c}35 \\
7.3 \\
8.4 \\
11 \\
19 \\
25 \\
6.8 \\
8.0 \\
5.1 \\
.0 \\
.0 \\
5.9 \\
1.9 \\
2.5 \\
2.9 \\
.0 \\
.0 \\
\end{array}$ & $\begin{array}{r}14.2 \\
15.7 \\
16.6 \\
16.8 \\
16.2 \\
16.8 \\
10.7 \\
19.5 \\
18.1 \\
4.3 \\
14.0 \\
15.8 \\
10.0 \\
12.3 \\
8.9 \\
10.2 \\
10.6 \\
\end{array}$ & $\begin{array}{l}9307.5 \\
9308.5 \\
9309.5 \\
9310.5 \\
9311.5 \\
9312.5 \\
9313.5 \\
9315.5 \\
9316.5 \\
9317.5 \\
9318.5 \\
9319.5 \\
9320.5 \\
9321.5 \\
9322.5 \\
9323.5 \\
9324.5 \\
\end{array}$ & $\begin{array}{r}.0 \\
3.7 \\
2.9 \\
.0 \\
2.4 \\
.0 \\
2.9 \\
.0 \\
.0 \\
.0 \\
1.8 \\
.0 \\
.0 \\
5.2 \\
4.2 \\
6.3 \\
4.7 \\
\end{array}$ & $\begin{array}{r}7.7 \\
9.2 \\
12.2 \\
9.4 \\
13.9 \\
8.0 \\
11.0 \\
11.9 \\
8.8 \\
12.4 \\
7.5 \\
13.7 \\
11.1 \\
12.6 \\
12.1 \\
14.3 \\
14.7 \\
\end{array}$ & $\begin{array}{l}9325.5 \\
9326.5 \\
9334.5 \\
9335.5 \\
9336.5 \\
9337.5 \\
9338.5 \\
9339.5 \\
9340.5 \\
9342.5 \\
9343.5 \\
9344.5 \\
9350.5 \\
9352.5 \\
9390.5\end{array}$ & $\begin{array}{r}4.5 \\
7.1 \\
.0 \\
.0 \\
.0 \\
4.1 \\
2.5 \\
2.4 \\
.0 \\
4.4 \\
3.6 \\
1.9 \\
.0 \\
.0 \\
.0\end{array}$ & $\begin{array}{r}11.3 \\
14.8 \\
7.3 \\
7.6 \\
14.7 \\
15.4 \\
12.9 \\
10.9 \\
8.1 \\
14.8 \\
15.2 \\
11.1 \\
\ldots . . . \\
\ldots . . . \\
\ldots . . .\end{array}$ \\
\hline \multicolumn{9}{|c|}{ Second Carneros sand } \\
\hline $\begin{array}{l}9408.5 \\
9412.5 \\
9413.5 \\
9414.5 \\
9415.5 \\
9416.5 \\
9417.5 \\
9428.5 \\
9430.5 \\
9434.5 \\
9435.5 \\
9436.5 \\
9440.5 \\
9442.5 \\
9453.5 \\
9454.5 \\
9455.5 \\
9461.5 \\
9462.5 \\
9476.5 \\
9477.5 \\
9478.5 \\
9479.5 \\
9484.5 \\
9485.5 \\
9486.5 \\
9487.5 \\
9488.5 \\
\end{array}$ & $\begin{array}{r}.0 \\
.0 \\
.0 \\
.0 \\
.0 \\
.0 \\
.0 \\
.4 \\
.1 \\
1.0 \\
1.3 \\
6.3 \\
.2 \\
.0 \\
4.3 \\
2.2 \\
2.5 \\
3.4 \\
.00 \\
.0 \\
17 \\
3.7 \\
7.1 \\
7.5 \\
2.5 \\
8.0 \\
.00 \\
.00 \\
.0 \\
\end{array}$ & $\begin{array}{r}9.9 \\
9.5 \\
14.1 \\
14.0 \\
8.9 \\
9.4 \\
11.0 \\
7.5 \\
10.2 \\
12.7 \\
11.3 \\
6.9 \\
11.7 \\
12.4 \\
10.8 \\
10.7 \\
11.9 \\
\ldots \ldots .2 \\
7.2 \\
18.3 \\
18.3 \\
18.2 \\
17.4 \\
19.1 \\
\ldots \ldots . . \\
\ldots \ldots . . \\
\ldots \ldots . \\
\end{array}$ & $\begin{array}{l}9489.5 \\
9490.5 \\
9491.5 \\
9492.5 \\
9493.5 \\
9494.5 \\
9495.5 \\
9496.5 \\
9497.5 \\
9498.5 \\
9499.5 \\
9500.5 \\
9501.5 \\
9502.5 \\
9503.5 \\
9504.5 \\
9505.5 \\
9506.5 \\
9507.5 \\
9508.5 \\
9509.5 \\
9510.5 \\
9511.5 \\
9512.5 \\
9513.5 \\
9514.5 \\
9515.5 \\
9516.5 \\
\end{array}$ & $\begin{array}{r}.0 \\
1.0 \\
6.7 \\
6.2 \\
5.3 \\
1.5 \\
2.0 \\
1.3 \\
3.0 \\
1.9 \\
7.1 \\
.5 \\
.0 \\
1.6 \\
4.0 \\
3.8 \\
2.9 \\
1.6 \\
1.9 \\
1.6 \\
1.6 \\
1.0 \\
1.7 \\
2.5 \\
3.1 \\
2.2 \\
1.1 \\
1.5 \\
\end{array}$ & $\begin{array}{r}12.8 \\
16.8 \\
17.3 \\
19.9 \\
16.5 \\
14.2 \\
17.1 \\
16.7 \\
14.8 \\
19.6 \\
9.0 \\
13.2 \\
13.6 \\
14.3 \\
13.7 \\
13.6 \\
11.8 \\
13.1 \\
14.8 \\
13.7 \\
12.4 \\
13.0 \\
14.4 \\
15.0 \\
11.5 \\
12.0 \\
\end{array}$ & $\begin{array}{l}9517.5 \\
9529.5 \\
9530.5 \\
9531.5 \\
9532.5 \\
9533.5 \\
9534.5 \\
9540.5 \\
9541.5 \\
9542.5 \\
9543.5 \\
9544.5 \\
9545.5 \\
9546.5 \\
9547.5 \\
9548.5 \\
9549.5 \\
9550.5 \\
9551.5 \\
9552.5 \\
9553.5 \\
9554.5 \\
9555.5 \\
9557.5 \\
9559.5 \\
9560.5\end{array}$ & $\begin{array}{r}1.1 \\
.0 \\
.0 \\
.0 \\
.0 \\
.0 \\
.0 \\
.0 \\
8.4 \\
5.8 \\
6.7 \\
7.2 \\
10 \\
6.1 \\
.0 \\
.0 \\
11 \\
11 \\
11 \\
13 \\
.0 \\
.0 \\
1.8 \\
.0 \\
.0 \\
.0\end{array}$ & $\begin{array}{r}15.0 \\
11.6 \\
13.7 \\
13.7 \\
\ldots \ldots .7 \\
13.7 \\
11.7 \\
13.1 \\
15.6 \\
19.2 \\
19.2 \\
16.3 \\
15.5 \\
15.9 \\
\ldots \ldots . . \\
16 . .5 \\
16.5 \\
17.2 \\
18.5 \\
17.0 \\
6.9 \\
17.5 \\
15.0 \\
9.8 \\
\ldots \ldots . . \\
\ldots . . .\end{array}$ \\
\hline
\end{tabular}

than 10 millidarcys. Numerous samples with no measureable permeability had as much as 14.1 percent porosity. Oil staining was noted by the Unit Operator in several beds of sandstone in the upper and middle parts of the Second Carneros sand.

Fossils in the Second Carneros sand consist mainly of Foraminifera (table 1). Some forms were poorly preserved, and other forms in some cores were questionably identified from internal molds. Scarce sponge spicules were found in a few cores from the middle part of the Second Carneros (R. S. Beck, written commun., 1969). Brownishblack shale in the upper part contained "mud pectens."

The top of the Second Carneros sand is defined by an upward change in dominant lithology from sandstone to shale. Because these rock types are interbedded to a considerable extent, both above and 
below the contact, determination of the contact from crushed-core samples is difficult. The spontaneous-potential curve of the electrical log suggests a fairly sharp contact (pl. 2).

The Second Carneros sand of the Carneros Sandstone Member in well $526-30 \mathrm{R}$ is mostly sandstone, 47 feet thick, that is siliceous in the basal bed and in the uppermost part. This sandstone is, for the most part, similar to that in the lower part of the Second Carneros sand in well 555-30R. The upper part of the Second Carneros of well $555-30 \mathrm{R}$, interbedded sandstone and shale, is apparently missing in well 526-30R. The absence of these beds might indicate a period of either nondeposition or erosion prior to deposition of the upper shale of the Carneros Sandstone Member. Another interpretation explaining the absence of these beds was proposed by R. J. Lantz and R. D. Carter (written commun., 1969). They suggest that an unconformity lies at the top of the Second Carneros sand in well 526-30R and that the overlying rocks (upper shale and First Carneros sand) should be assigned to the Gould Shale Member of the Monterey Shale. Later work by J. C. Maher, R. J. Lantz, and R. D. Carter (written commun., 1969) and by the writer has resulted in the interpretation used in the present report.

The upper shale of the Carneros Sandstone Member is $\mathbf{5 5}$ feet thick in well 555-30R, where it is composed chiefly of shale and some sandstone and siltstone. The color of the shale is dark gray to brownish black in the lower part and medium dark gray in the upper part. Some shale is silty, phosphatic, and slightly limy; shale at the top is finely sandy. Laminae, lenses, and thin beds of siltstone and very fine to. medium-grained sandstone are common in the upper shale of the member. Sandstone dikes are present in the lower part. Contorted bedding in the upper part probably indicates soft-sediment deformation.

Analyses of three cores of sandstone from the upper shale showed no measurable permeability (table 3 ); the porosity was not determined. The Unit Operator reported no oil stains in the cores.

Foraminifera were found in all cores of the upper shale, and these are given in table 1. The number of species identified is somewhat less than for the Second Carneros sand but considerably more than for the overlying First Carneros sand. In addition to the Foraminifera, shale near the base contained fish scales and "mud pectens," and a bed near the middle contained fish scales and plant fragments.

The upper shale of the Carneros Sandstone Member may grade upward into the First Carneros sand in well 555-30R. A gradational contact is suggested by the very silty and finely sandy shale at the top of the upper shale and by the slope of the spontaneous-potential curve of the electrical $\log (\mathrm{pl} .2)$. Core recovery in the basal part of the First Carneros was incomplete; the contact may lie slightly higher 
than indicated in the detailed sample log and within an interval of lost core.

The upper shale of the Carneros Sandstone Member is 45 feet thick in well 526-30R. The shale is predominantly medium dark to dark gray, silty, and mostly siliceous, but the uppermost part is medium gray, slightly limy, and not siliceous. These rocks seem to differ notably from those in the upper shale of the Carneros in well 55530R. The difference might be ascribed to erroneous logging of caving siliceous shale from the Gould Shale Member of the Monterey Shale in well 526-30R. Assignment of the upper shale to the Carneros in this well is based primarily on its stratigraphic position. In addition, a few Foraminifera (Haplophragmoides trullissata and Uvigerinella cf. U. obesa) which are suggestive of a Carneros or Media age were found by R. S. Beck in the rotary samples from a depth of 10,20010,230 feet. Although this fossil collection is assigned a depth 4-34 feet below the top of the Second Carneros sand (pl. 1), there is a good possibility that the fossils actually came from strata above the Second Carneros and did not appear in the higher samples because of rotarysample lag.

The type of contact between the upper shale and the First Carneros sand in well 526-30R is unknown because of the lack of cores. The electrical log suggests only minor differences in the electrical properties of the rocks below and above the contact (pl. 1).

The First Carneros sand of the Carneros Sandstone Member is 88 feet thick and consists almost entirely of medium-light-gray limy silty sandstone. Grain size ranges from very fine to very coarse and sorting is commonly poor. Phosphatic grains are found mainly in the upper part. Dark-gray shale laminae are fairly common in some beds. Contorted bedding is apparently absent, providing a notable contrast with the underlying units. A few samples exhibited graded bedding; others showed pinch-and-swell features and load casts. A very thin bed of phosphatic siliceous shale lies in the upper part.

The porosity and permeability of the sandstone in the First Carneros sand were determined mostly at 1 -foot intervals (table 3 ). The porosity ranges from 4.3 percent to 19.5 percent and averages about 12 percent. The permeability ranges from 0 to 35 millidarcys and is generally higher in the upper part. Sixteen core samples had no measurable permeability but had porosity as high as 14.7 percent. Most cores of sandstone showed some oil staining according to the Unit Operator.

Foraminifera are present in parts of the First Carneros sand in well 555-30R (not listed on pl. 2). Although the microfaunal assemblage is very small (table 1 ), a few species indicate a Saucesian age (R. S. Beck, written commun., 1952). Sandstone near the middle of 
the First Carneros includes pebble-sized shell fragments. The very thin siliceous shale bed in the upper part is very fossiliferous; Foraminifera are abundant.

The contact between the First Carneros sand and the overlying Media Shale Member in well 555-30R probably lies about 10 feet above the depth at which coring was started. The top of the Carneros is interpreted from the electrical log because there is a missing-sample interval above the uppermost core (pl. 2). A gradational contact seems likely, from the evidence of the electrical log.

The First Carneros sand is 8 feet thick in well 526-30R, where it consists of light-gray very fine to fine-grained very silty sandstone in which medium grains are scattered. The sandstone is clayey and slightly limy and glauconitic. Some hard sandstone appears to be tightly cemented. The sandstone is assigned to the Carneros Sandstone Member because it more closely resembles the sandstone in the Second Carneros sand than the thin sandstone in the overlying Gould Shale Member of the Monterey Shale. The First Carneros sand in well 526-30R is also lithologically similar to part of the First Carneros in well 555-30R, except for the absence of glauconite in well 555-30R.

Fossils seem to be absent in the First Carneros sand in well 52630R. The First Carneros lies within the depth interval (10,140-10,170 feet) doubtfully assigned to a paleontologic sample that yielded a few Foraminifera (Siphogenerina branneri and Pullenia miocenica) of post-Carneros age. These microfossils probably came from the Gould Shale Member and indicate caving or lagging of the rotary samples.

The Carneros Sandstone Member is generally overlain by the Media Shale Member. In well 526-30R the Media is apparently missing and the Carneros is overlain unconformably by the Gould Shale Member of the Monterey Shale. This interpretation is based largely on the absence in the rotary samples of Foraminifera diagnostic of the Media and the presence of two species (Siphogenerina branneri and Pullenia miocenica) characteristic of the Gould in samples assigned by the driller to the depth 10,140-10,170 feet, an interval extending 27 feet below the top of the Carneros. The thickness of the First Carneros sand in well 526-30R is considerably reduced compared with the thickness in well 555-30R; this difference in thickness may indicate erosion of part of the First Carneros sand before deposition of the overlying beds.

MEDIA SHALE MEMBER

The term "Media Shale" was first published by Cunningham and Barbat (1932, table 1). A type locality for the Media was not formally designated but was presumed by Heikkila and MacLeod (1951, p. 8) 
to be on Media Agua Creek. Exposures of the Media on Zemorra Creek were designated the type section by Dibblee (1973). The Media Shale Member on Zemorra Creek, described by Woodring, Stewart, and Richards (1940, p. 130), consists of dark silty partly foraminiferal shale, 920 feet thick, which includes a few zones of calcareous concretions, a hard 5-foot sandstone bed 160 feet below the top, and a 50-foot cherty shale 40 feet below the sandstone. Farther northwest, in the Bitterwater Creek area, shale of the Media becomes increasingly siliceous upward, and the middle part of the member includes numerous hard limestone beds averaging about 3 feet in thickness (Heikkila and MacLeod, 1951, p. 9, 10).

The Media Shale Member has a drilled thickness of 205 feet in well $555-30 \mathrm{R}$ (pl. 2). A dip of $24^{\circ}$ was indicated in one dipmeter survey made in the upper part, and the Unit Operator reported apparent dips of $40^{\circ}-46^{\circ}$ in two cores. The true thickness may be about 150 feet.

The Media consists almost entirely of medium dark-gray partly limy hard shale. The lower part is slightly phosphatic; the middle and upper parts are mostly siliceous. Slickenside surfaces are found in both core samples of the shale, and fractures in the upper core are filled with dolomite, calcite, and pyrite. Tarry oil on some fractures in the lower core was noted by the Unit Operator.

Fossils in the Media Shale Member include Foraminifera (table 1), fragments of fish bones, and "mud pectens". The foraminiferal assemblage in the two cores is diagnostic of the upper Saucesian Stage (R. S. Beck, written commun., 1952).

The top of the Media Shale Member is difficult to determine in well 555-30R because the Buttonbed Sandstone Member, uppermost division of the Temblor Formation in the Temblor Range, is absent in the western part of the Elk Hills oil field and adjacent areas. In well $555-30 \mathrm{R}$ the Media is overlain by rocks assigned to the Gould Shale Member of the Monterey Shale (not shown on pl. 2). A study of the Foraminifera in two cores from depths of 9,094-9,100 feet and 8,9868,996 feet indicates that the contact lies between these cores. According to R. S. Beck (written commun., 1952), the deeper of these cores contains two species of Foraminifera, Siphogenerina transversa and Cibicides americanus, not found in beds above the basal part of the Media in the Chico Martinez Creek area. In the shallower of these cores, Beck found a few poorly preserved specimens of Siphogenerina cf. $S$. branneri, a fossil that he considers restricted stratigraphically to the Gould Shale Member of the Monterey and to the underlying Buttonbed Sandstone Member of the Temblor. In well 555-30R the position of the contact between the Media and the Gould is determined primarily by slight changes in electrical-log character and in accordance with the available paleontologic data. 


\section{MIOCENE ROCKS}

\section{MONTEREY SHALE}

For more than a century the name "Monterey" has been applied in various ways to rocks of Miocene age in California. The term "Monterey Formation" was first used by Blake $(1855$, p. 331) in describing Tertiary strata on a hill about 2 miles southeast of the town of Monterey (fig. 1). According to Louderback (1913, p. 194, 195), the context of Blake's report indicates that he did not intend to name or define a stratigraphic unit but rather used the term in a locality sense for the type of material at Monterey. Regardless of Blake's intentions, most writers have applied the name Monterey to a stratigraphic unit of formation rank. A critical review of the early literature concerning the Monterey and the underlying Vaqueros was included in the report by Louderback (1913, p. 193-232).

The Monterey Shale at the type locality near Monterey was described by Martin (1912), who estimated the thickness at 2,000 feet and listed the molluscan fossils. Hanna (1928) also described the Monterey at the type locality and summarized the fauna and flora.

The Monterey Shale was recognized by early workers along the west side of the San Joaquin Valley about the turn of the century. Eldridge (1903, p. 306-310) briefly described the formation near Coalinga, McKittrick, and Sunset. Many other writers have used the term "Monterey Shale" or "Formation" for the siliceous and diatomaceous shales of Miocene age along the west side of the Valley. Geologists have differed considerably regarding the stratigraphic position of the upper contact and, to a lesser extent, the lower contact of the formation.

The name "Monterey" has also been used as a group name to include the Vaqueros Sandstone and the overlying siliceous and diatomaceous shaly rocks generally called Monterey Shale or Formation. Usage of the name "Monterey" in a group sense was apparently intended by Lawson (1893, p. 24), who applied the term "Monterey series" to Miocene rocks near Carmel, about 3 miles south of the town of Monterey. Other early writers, notably Louderback (1913, p. 232), also used the term "Monterey series" in a group sense. Usage of the term "Monterey" as a group name made necessary a new formation name for the rocks formerly designated Monterey Shale. These rocks were called Maricopa Shale by English (1916, p. 198) in a report on the Cuyama Valley (fig. 3), about 25 miles south-southwest of Elk Hills, but he did not specify or describe a type section for the formation. Pack (1920, p. 38) described the type section of the Maricopa Shale in secs. 13 and 24, T. 11 N., R. 24 W., S.B.B. and M., about a mile south of Maricopa (fig. 3 ) where the thickness is 4,800 feet. 
English (1918, p. 228), in a report on the Salinas Valley, stated that the Maricopa Shale in the vicinity of its type section included beds equivalent not only to the Monterey Shale of former usage but also beds equivalent to part of the overlying Santa Margarita Formation. Because of this relation, the term "Salinas Shale" was proposed by English (1918, p. 228) to replace the term "Monterey Shale" in the Salinas Valley. The name Salinas Shale, was applied to exposures of diatomaceous shale overlying the Vaqueros Sandstone on the west side of Salinas Valley, about 70 miles northwest of Elk Hills, but a type section was not designated.

According to Woodring, Stewart, and Richards (1940, p. 122), "The raising of Monterey to group rank was based on the view *** that the Vaqueros sandstone and Monterey shale together constitute a stratigraphic unit of varying lithologic facies separated from the overlying Santa Margarita sandstone by a widespread unconformity ***." This unconformity was described as early as 1904 by Fairbanks (1904, p. 4, 8, 10), who also named and described the Santa Margarita Formation from exposures near Santa Margarita in the Salinas Valley. Later more detailed work, mainly during the twenties, showed that the contact between the Monterey and Santa Margarita was not an unconformity of great regional extent (Reed, 1933, p. 206, 207). Hanna (1928, p. 974) mentioned the possibility that the Santa Margarita is a sandy phase of all or part of the Monterey, and later workers in the Coast Ranges generally agreed that sandstones of the Santa Margarita interfinger laterally with the upper part of the Monterey Shale (Woodring and others, 1940, p. 122, 123). A proposal to abandon the terms "Monterey Group," "Maricopa Shale," and "Salinas Shale" was made by Woodring, Stewart, and Richards (1940, p. 123). These writers recommended application of the term "Monterey Shale" to "*** Miocene strata in the Coast Ranges characterized by hard siliceous shale and soft shale containing microscopic siliceous fossils, regardless of varying chronologic relations of these strata within the Miocene, in accordance with the principle that a formation need not be of the same age from place to place."

The Monterey Shale on the west side of the San Joaquin Valley was divided into members many years ago. Most of the members were informally named, and some were more accurately considered biostratigraphic zones because their identification depended largely on the contained microfauna. The members identified by petroleum geologists in the vicinity of Chico Martinez Creek, listed and briefly described in a guidebook by the San Joaquin Geological Society (1959, p. 13), include, in upward order, the Gould Shale, Devilwater Silt, McDonald Shale, Antelope Shale, Chico Martinez Chert, and Chico Martinez (Belridge) Diatomite. According to the San Joaquin 
Geological Society (1959, p. 13), the McDonald Shale, Antelope Shale, and Chico Martinez Chert Members are equivalent to the McLure Shale Member, a stratigraphic unit first defined as a formation (Henny, 1930) in the area bordering McLure Valley (now known as Sunflower Valley) south of Reef Ridge (fig. 3 ).

The exposed rocks of the Monterey Shale in the Temblor Range and adjacent foothills to the northeast were studied and mapped on a regional basis by Dibblee (1973), who briefly reviewed the nomenclature and longstanding correlation problems. He designated the exposures along Chico Martinez Creek (fig. 3) on the northeast flank of the Temblor Range as a reference section for the Monterey Shale and its members. The members of the Monterey adopted by Dibblee (1973) northeast of the San Andreas fault include, in upward order, the Gould Shale, Devilwater Shale, McLure Shale, and Belridge Diatomite Members. Where exposed, these units are separable on the bases of lithologic composition and weathering characteristics. According to Dibblee (1973) the McLure Shale Member consists of siliceous shale that, in outcrops outside the Chico Martinez Creek area, cannot be separated with certainty into the McDonald Shale, Antelope Shale, and Chico Martinez Chert Members of local usage.

In the Elk Hills oil field, the Monterey Shale in well 526-30R has a drilled thickness of 4,108 feet. The true thickness is considerably less, but difficult to calculate, because dipmeter surveys indicate that the rocks generally dip about $20^{\circ}-45^{\circ}$ toward the northeast, east, and southeast. The well-bore deviates as much as $25^{\circ}$ th.irough the formation, mostly toward the southwest. The true thickness is probably of the order of 3,500-3,600 feet.

The subdivision of the Monterey Shale found rnost useful in the subsurface of the Elk Hills oil field differs in part from that adopted for the Temblor Range by Dibblee (1973). The Gould Shale Member, and in some wells the overlying Devilwater Shale IMember, are identified in the oil field. The Devilwater is overlain the McDonald Shale Member of local usage. Rocks of the Monterey Shale above the McDonald in the Elk Hills oil field are here named the Elk Hills Shale Member, and a type section is established in well 526-30R. The McDonald Shale Member of local usage and the Elk. Hills Shale Member are stratigraphically equivalent to the McLure shale Member and possibly the Belridge Diatomite Member, as present at Chico Martinez Creek. If strata equivalent to the Belridge are present in the Elk Hills oil field, they cannot be distinguished from the underlying rocks.

\section{GOULD SHALE MEMBER}

The Gould Shale Member was first mentioned by Cunningham and Barbat (1932, table 1), who considered this a member of the Temblor Formation but, through an oversight, omitted in the left-hand column 
of their correlation chart a line separating the Temblor from the Monterey. This incidental mention of the term "Gould" was inadequate for the purpose of establishing a stratigraphic unit, and accordingly Barbat $(1932$, p. 611, 612) defined the Gould as the 220-230 feet of beds overlying their Button bed member of the Temblor and underlying the Valvulineria californica zone of the Monterey Shale. The member was named for Gould Hill (fig. 3) which is near the type locality in sec. 14, T. 29 S., R. 20 E., (Mount Diablo base line and meridian), Kern County. Because of faunal affinities between the Gould and the upper part of the Temblor, Cunningham and Barbat (1932, p. 420) thought the Gould to be probably Temblor in age. Goudkoff $(1934$, p. 468), on the other hand, wrote "the foraminiferal assemblage of the Gould shale $* * *$ is much more closely related to that of the [overlying] Valvulineria californica zone than to that of the type Temblor." For many years the Gould has been considered the basal shale member of the Monterey Shale along the west side of the San Joaquin Valley.

Exposures of the Gould Shale Member on Chico Martinez Creek (fig. 3) consist of hard shale, about 550 feet thick, that is light brown, brittle, laminated, siliceous, and partly limy (San Joaquin Geol. Soc., 1959, p. 13). In the Temblor Range, Dibblee (1973) applied the name "Gould Shale Member" to siliceous shale in the Monterey Shale that conformably overlies the Temblor Formation and underlies the Devilwater Shale Member. As thus defined and mapped, the Gould presumably includes strata equivalent in age to the Devilwater Shale Member in the southeastern part of the range (Dibblee, 1973). Many geologists have combined the Gould and Devilwater Members because of the difficulty in separating these units lithologically in areas away from the vicinity of Chico Martinez Creek.

The Gould Shale Member in well 526-30R has a drilled thickness of 185 feet, but the upper contact is approximate because it is difficult to determine. The rocks dip about $20^{\circ}-30^{\circ}$ northeast, according to a dipmeter survey, and the well bore deviates $5^{\circ}-9^{\circ}$ southwest. The true thickness of the member probably approximates 170 feet.

The Gould consists of medium- to dark-gray and brownish-gray shale, and, in the upper half, a few thin beds of limestone and sandstone (pl. 1). The lower half of the member is almost entirely siliceous shale; the shale in the upper half is partly siliceous and partly limy. Some siliceous shale in the upper part has calcite-filled fractures. The limestone is chiefly brownish gray, dense to very fine grained, and argillaceous. The sandstone is medium light to medium dark gray, very fine to fine grained, silty, and slightly dolomitic.

Much of the shale and the limestone of the Gould contain microfossils, mainly Foraminifera (table 2). The upper part contains the 
foraminifers Siphogenerina branneri, Valvulineria robusta, and Hemicristellaria beali. According to R. S. Beck, (written commun., 1969) these fossils, among others, characterize the Gould Shale Member and, where present, the underlying Buttonbed Sandstone Member of the Temblor Formation.

The upper contact of the Gould Shale Member is placed at the top of the shale that contains Siphogenerina branneri. The position of the contact is approximate because the upper part of the Gould and the lower part of the overlying shale are lithologically similar. The assignment of the overlying unit for an interval of about 160 feet is questionable; it is called the Devilwater(?) Shale Member of the Monterey.

\section{DEVILWATER(?) SHALE MEMBER}

The identification of the rocks above the Gould Shale Member is uncertain in well 526-30R. The presence of the Devilwater Shale Member in this well is suggested by electrical-log correlations with nearby wells where the member is identified by the contained microfauna. These correlations are not supported by the microfossil determinations made for well 526-30R, as discussed below. Therefore, the rocks above the Gould are called Devilwater(?) Shale Member.

The Devilwater Shale Member was originally called the Devilwater Silt, presumably for exposures in Devilwater Creek (fig. 3). The name was first used, but not defined, by Bailey $(1939$, p. 67, pls. 1,3$)$ in a brief description of the Wasco oil field. Dibblee (1973) modified the name to Devilwater Shale Member and specified the type section at Chico Martinez Creek. Prior to the usage of the term "Devilwater," these strata were generally called the Valvulineria californica zone. This foraminiferal zone, which lies at the base of the Monterey Shale in its type area (Goudkoff, 1931, p. 840), has been well known and widely used for faunal correlation by micropaleontologists for many years.

The Devilwater Shale Member is 1,190 feet thick at the type section on Chico Martinez Creek where it consists of soft foraminiferal clayey shale and silty mudstone overlying the siliceous shale of the Gould Shale Member and underlying the siliceous McLure Shale Member (Dibblee, 1973). In the general area of Chico Martinez Creek, the Devilwater consists of gray, buff, and brown silty shale and siltstone, and these rocks are massive, nodular, clayey, and locally siliceous and calcareous (San Joaquin Geol. Soc., 1959, p. 13).

In well 526-30R rocks assigned to the Devilwater(?) Shale Member have a drilled thickness of 161 feet, but the upper contact is approximate. A dipmeter survey indicates that the rocks dip about $30^{\circ}-40^{\circ}$ northeast and the well bore deviates $9^{\circ}-15^{\circ}$ southwest. The true thickness is probably about 150 feet. 
Shale, sandstone, and siltstone compose the Devilwater(?) Shale Member in well 526-30R. The shale is chiefly medium dark to dark gray, but shale at the top of the member is brownish gray, finely banded with dark gray or dark brownish gray, and very siliceous. The sandstone, found in the middle and upper parts, is mostly medium gray, very fine to medium grained, silty, siliceous, and slightly dolomitic. Porosity of the sandstone appears to be very low. The siltstone is medium gray, sandy, and siliceous.

Microfossils are present in a few beds of medium-gray slightly limy shale in the lower part of the Devilwater(?) Shale Member. In his study of the Foraminifera from this part of the Monterey (table 2), R. S. Beck (written commun., 1969) did not find a faunal assemblage (Valvulineria californica zone) diagnostic of the Devilwater Shale Member. In rotary samples from the interval 9,900-9,960 feet, Beck identified Bulimina ovata, Uvigerina hootsi, Cassidulina crassa, and Buliminella subfusiformis. These species, especially Uvigerina hootsi, suggest that the Devilwater may be absent in this well and the strata in the interval 9,900-9,960 feet may be the lower part of the McDonald Shale Member of local usage. On the other hand, the daily drilling reports for well 526-30R indicate considerable difficulties in drilling the rocks from 9,700-9,960 feet. The Foraminifera listed above may have come from fragments of the overlying McDonald which were knocked or scraped from the wall of the hole during drilling operations.

The contact with the overlying McDonald Shale Member of local usage is rather arbitrarily placed at the top of the brownish-gray very siliceous shale. The contact coincides with a fairly abrupt upward decrease in electrical resistivity, but the spontaneous-potential curve gives no indication of the change in lithology (pl. 1).

\section{M'DONALD SHALE MEMBER OF LOCAL USAGE}

The McDonald Shale Member of local usage was probably named informally by petroleum geologists from exposures southwest of the McDonald oil field (Foss and Blaisdell, 1968, p. 37), which lies about 21 miles northwest of Elk Hills. The first published mention of the term apparently was by Cushman and Goudkoff $(1938$, p. 1), but they did not describe the member. They noted that the foraminifer Pulvinulinella gyroidinaformis characterized a very widespread stratigraphic zone, commonly called the McDonald Shale, along the west side of the San Joaquin Valley. Cushman and Goudkoff also mentioned that the basal beds of the McLure Shale along Reef Ridge are stratigraphically equivalent to the Pulvinulinella gyroidinaformis zone. The McDonald was described and mapped in the Temblor Range southwest of McKittrick by Simonson and Krueger (1942, p. 1616,1617 , fig. 8), who wrote that this member was more silty and massive and darker colored than the underlying Devilwater and 
Gould Members, undifferentiated. They also noted a diagnostic foraminiferal fauna in the McDonald.

According to the San Jcaquin Geological Society $(1959$, p. 13), the McDonald Shale Member on Chico Martinez Creek (fig. 3) is about 2,300 feet thick and consists of light-buff to reddish-brown silty punky to siliceous laminated shale and a few beds of limestone. The McDonald was delineated on a map of the Chico Martinez Creek area (San Joaquin Geol. Soc., 1959, p. 6, 7), and it has been identified in numerous reports on subsurface rocks in western Kern County. The name "McDonald" was not adopted by Dibblee (1973) in his regional study mainly because these rocks and the overlying rocks are mostly siliceous shale that are difficult to distinguish in field mapping outside the Chico Martinez Creek area.

In the Elk Hills oil field, the McDonald Shale Member of local usage is a distinct lithologic unit, as determined from extensive stratigraphic work by J. C. Maher, R. J. Lantz, and R. D. Carter. The lower contact is difficult to determine in well 526-30R as described above.

The McDonald Shale Member of local usage in well 526-30R has a drilled thickness of 257 feet. Dipmeter surveys indicate the rocks dip about $25^{\circ}-45^{\circ}$ toward the northeast, east, and in the uppermost part, the southeast. The well bore deviates $11^{\circ}-15^{\circ}$ toward the southwest. The true thickness is probably about 240 feet.

The McDonald consists almost entirely of shale that is medium to dark gray, dark brownish gray, and, in the upper part, brownish black. Siliceous partly cherty shale dominates the upper third of the member. The lower half includes a few thin beds of medium-gray fairly soft limy shale and gray very fine to fine-grained silty sandstone. Two beds of light-gray to pale olive flaky shale, possibly bentonitic, are questionably logged in the McDonald. The upper bed contains scattered sand grains. The positions of these two beds seem to be indicated by low resistivity values at 24 feet above the base and 36 feet below the top of the member ( $\mathrm{pl} .1$ ), and the resistivity curve suggests a third, similar bed near the middle.

Fossils are generally scarce in the McDonald, but R. S. Beck (written commun., 1969) found some Foraminifera in parts of the member (table 2). These include Uvigerina hootsi, Bolivina parva, and a fragment of Cassidulina cf. C. monicana, fossils which Beck considers characteristic of the McDonald. The diagnostic foraminifer Pulvinulinella gyroidinaformis was not found in well 526-30R, although it is present (but rare) in one or two nearby wells (R. S. Beck, written communs., 1967).

The upper contact of the McDonald Shale Member of local usage in well 526-30R is placed at the top of the dark-colored siliceous cherty shale. The relative coarseness of the overlying sandstone sug- 
gests that this contact might be a disconformity of at least local importance. The lithologic change at the top of the McDonald coincides with changes in both the spontaneous-potential and the resistivity curves of the electrical log (pl. 1).

\section{ELK HILLS SHALE MEMBER}

In the Elk Hills oil field, the rocks of the Monterey Shale above the McDonald Shale Member of local usage make up a thick extensive stratigraphic unit that contains major oil reserves. A varied and confusing stratigraphic nomenclature has been applied to these rocks. The name "Antelope Shale" probably has been most used, but in at least four ways, since Noble (1940, fig. 1) first used the name in a brief discussion of the Rio Bravo oil field. That discussion included neither a type locality nor an adequate description for the Antelope. In the eastern part of Elk Hills, the term "Antelope" was applied by Park and Land (1955, pl. 6) to the uppermost part of the Monterey Shale (above the $\mathrm{N}$ horizon, pl. 1); the underlying strata, downward to the McDonald, were called Stevens. The term "Stevens sand" is commonly used in an economic sense for any sandstone in the Monterey above the McDonald Shale Member of local usage. In the Elk Hills oil field, Church and others (1957) used the term "Antelope Shale" for rocks above the McDonald and below the N horizon (pl. 1), and they called the overlying Miocene rocks the McLure Shale and Reef Ridge Shale, undifferentiated. Lorshbough (1967, p. 36, pls. 4, 6) used the term "Antelope Shale" for all rocks of the Monterey above the McDonald in the Elk Hills oil field. The Unit Operator for this field called the lower part of these strata the Antelope Shale and used the name "Brown shale" for the upper part. The top of the Antelope Shale of the Unit Operator is identified on plate 1 . Because of these differing usages, the name "Antelope" is not used in this report. The new name "Elk Hills Shale Member" is here given to the rocks of the Monterey Shale lying above the McDonald Shale Member of local usage and below the Reef Ridge Shale.

The type section for the Elk Hills Shale Member of the Monterey Shale is in well 526-30R between drilled depths of 6,035 and 9,540 feet (pl. 1). According to a dipmeter survey, the rocks in the upper half dip generally $15^{\circ}-35^{\circ}$. In the lower half, the dip seems to increase considerably, and below a depth of 7,860 feet, many dips exceeding $60^{\circ}$ are indicated. In general, the direction of dip varies from northeast to southeast. Many pronounced changes in amount and direction of dip within closely spaced vertical intervals cause considerable doubt about the usefulness of much of the dipmeter data. Some of these striking variations in dip and strike probably measure fractures in the rocks rather than bedding. The deviation of the well bore through the Elk Hills Shale Member ranges from $4^{\circ}$ to $25^{\circ}$, and the direction 
of deviation is southwest to west. The thickness of the member is about 3,000-3,100 feet, but uncertainties regarding dip and strike of the rocks preclude an accurate calculation of the thickness.

The Elk Hills Shale Member is divided, in upward order, into the $\mathrm{E}, \mathrm{DD}, \mathrm{D}, \mathrm{C}, \mathrm{B}, \mathrm{A}$, and $\mathrm{N}$ zones (pl. 1), following recommendations by J. C. Maher, R. D. Carter, and R. J. Lantz (written commun., 1970). This subdivision, based chiefly on electrical-log characteristics, is modified in part from one used by the Elk Hills Engineering Committee (1957, p. 7, fig. 1) for reservoir-engineering purposes. The Committee divided the rocks of the Monterey Shale above the Devilwater Shale Member into seven units called, in upward order, the PG, $\mathrm{DD}, \mathrm{D}, \mathrm{C}, \mathrm{B}, \mathrm{A}$, and $\mathrm{N}$ intervals; these intervals, together with the overlying Reef Ridge Shale, constitute the Stevens zone according to the Unit Plan Contract between the U.S. Navy and Standard Oil Company of California. In an earlier report on the Elk Hills oil field, Wells (1952, p. 244) used the same letter designations for a similar subdivision of the rocks below the $\mathrm{N}$-point electrical-log marker ( $\mathrm{N}$ horizon, pl. 1). The PG interval of the Elk Hills Engineering Committee included the McDonald Shale Member of local usage and the lower part of the overlying member herein named the Elk Hills Shale Member. In this report the McDonald is identified, and the lower part of the Elk Hills Shale Member is called the $\mathrm{E}$ zone. The seven zones are useful in making correlations within the Elk Hills oil field, and they are described below using drilled thicknesses.

The E zone of the Elk Hills Shale Member is 825 feet thick in well $526-30 \mathrm{R}$. The rocks consist mainly of shale, siltstone, and sandstone. The shale is mostly medium dark to dark gray, but in the lower part, much of it is brownish gray. Siliceous and cherty shale is abundant in the lower part above the basal sandstone. The'siltstone, found mainly in the middle and upper parts, is medium light to dark gray and partly sandy. Sandstone occurs at the base of the zone and in several beds near the middle and in the upper part. The basal sandstone, 23 feet thick, is medium light gray, very fine to medium grained, silty, slightly dolomitic, and siliceous in the upper few feet. The grain size increases downward, and the lower part includes some coarse and very coarse grains. Feldspar grains and mica are the principal accessory minerals. Sandstone in the middle and upper parts of the zone is generally similar to the basal sandstone. Most sandstone beds in the middle part are probably no more than three feet thick. Several sandstone beds apparently are fairly porous, and one bed near the top appears oil stained. Two thin beds of limestone lie in the lower-middle part of the zone. The limestone is pale yellowish brown, very fine grained to dense, dolomitic, and argillaceous. A thin bed of light-gray to yellowish-brown flaky shale, possibly bentonitic, lies 
about 140 feet above the base of the zone. This shale contains scattered sand grains and mica.

Fossils seem to be rare in the E zone of the Elk Hills Shale Member. Some beds of sandstone and siltstone in the upper and middle parts contain carbonaceous or coaly fragments. A bed of siltstone near the base may contain diatom fragments. R. S. Beck (written commun., 1969) found a few specimens of Haplophragmoides(?) sp. and a few other indeterminate fossil fragments in several samples from the $\mathbf{E}$ zone (table 2).

The contact between the $\mathrm{E}$ zone and the overlying DD zone is marked by an upward change from sandy siltstone to shale. The contact is indicated on the resistivity curve of the electrical log by a sharp upward decrease in the resistivity; the spontaneous-potential curve gives almost no indication of the lithologic change (pl. 1). In the Elk Hills oil field, the top of the $\mathrm{E}$ zone is readily identified on most resistivity logs of wells that reached the zone.

The DD zone, 248 feet thick in well 526-30R, consists of dusky yellowish-brown to dark-gray silty shale, medium-dark-gray siltstone, and, in the lower half, some light- to medium-gray silty sandstone. Many of the beds are siliceous. A few beds near the top may contain dark-brownish-gray to brownish-black dense chert, although this chert may have caved from higher strata. The sandstone is mostly very fine to fine grained, and the porosity appears to be low. Shale at the base of the zone is light to medium gray, silty to sandy, flaky to splintery, and possibly bentonitic. Electrical resistivity of this shale is very low ( $\mathrm{pl} .1$ ). The lower part of the zone includes a thin bed of pale yellowish-brown limestone, and the middle part includes a thin bed of dusky yellowish-brown to brownish-black dolomite. Both carbonate beds are very fine grained and argillaceous.

Fossils are rare in the DD zone. Scattered carbonaceous fragments are present in some of the sandstone. Finely color banded siltstone and shale in the upper half of the zone may contain diatom fragments. From a sample of the upper part, R. S. Beck (written commun., 1969) questionably identified two foraminifers, Bolivina sp. and Globigerina bulloides (table 2). He noted the presence of the diatom Coscinodiscus sp. near the middle of the zone.

The top of the DD zone is marked by an upward change from darkgray and grayish-black shale to brownish-gray sandy siliceous siltstone. The change in lithology is indicated on both the spontaneouspotential and resistivity curves of the electrical log (pl. 1).

The D zone of the Elk Hills Shale Member is 661 feet thick in well $526-30 \mathrm{R}$, where it is chiefly siltstone and silty shale. Most of the siltstone probably consists largely of diatom fragments, although few diatom fossils or molds were recognized during the sample study. The 
grain size of this sutstone, slightly smaller than coarse silt, is strikingly uniform for the most part. For this rock type, the term "diatomaceous siltstone" is used here; some writers use the term "diatomite." This siltstone is pale yellowish brown to brownish gray, and finely color banded dark gray; it is siliceous and in part slightly dolomitic. Much of the siltstone apparently has considerable porosity, as indicated by water-absorption tests made during the sample examination. Most of the shale is brownish gray to dark gray; some is pale yellowish brown or grayish black. Nearly all the shale is siliceous, and some probably is composed largely of diatom fragments. Chert occurs in much of the $\mathrm{D}$ zone, either in thin beds or as nodules in other rock types. The chert is dusky brown to brownish black and dark gray, dense, and partly color banded. The $D$ zone includes several thin beds of sandstone and dolomite. The sandstone, found in the lower half of the zone, is light to medium dark gray, very fine to medium grained, silty, and partly siliceous. The dolomite is pale yellowish brown to brownish gray, dense to very fine grained, argillaceous, and hard.

Microfossils are present in much of the $\mathrm{D}$ zone, but many of them are too broken to identify. In a few samples R. S. Beck (written commun., 1969) identified Haplophragmoides sp., Globigerina bulloides (table 2), Radiolaria, and some echinoid spines. Carbonaceous material seems to be absent.

The upper contact of the $\mathrm{D}$ zone is marked by an upward change from siltstone to shale. The contact is readily identified on the spontaneous-potential curve of the electrical log, but it is poorly defined by the resistivity curve (pl. 1).

The $\mathrm{C}$ zone, 367 feet thick in well 526-30R, consists predominantly of brownish-gray to dark-gray shale. The shale is silty and partly siliceous. The zone includes some interbedded diatomaceous siltstone and several thin beds of sandstone and dolomite. The siltstone closely resembles that in the $\mathrm{D}$ zone. The sandstone is light to medium gray, very fine to fine grained, silty, and partly siliceous and dolomitic. Dolomite, found chiefly in the lower half of the $\mathrm{C}$ zone, is very similar to that in the $\mathrm{D}$ zone.

Fossils are generally rare in the $\mathrm{C}$ zone. R. S. Beck (written commun., 1969) identified Haplophragmoides sp. and Globigerina bulloides in a few samples and, in the upper part, fragments of Bathysiphon sp. (table 2).

An upward change from shale to sandstone marks the top of the C zone. This contact is readily identified on the electrical log (pl. 1).

The B zone, 379 feet thick, consists of interbedded siltstone, shale, and sandstone. The pale-yellowish-brown to brownish-gray siliceous diatomaceous siltstone closely resembles siltstone in the $\mathrm{D}$ zone. 
Dark-gray very thin streaks and stringers are common. Siltstone at the top may contain dusky-brown dense vitreous chert. In the lower part of the B zone, some siltstone is medium light to dark gray, sandy, and siliceous. The shale is medium dark to dark gray and dusky brown to brownish gray, silty, and mostly siliceous; a few beds are olive gray or yellowish gray. The sandstone occurs in beds less than 10 feet thick. The sandstone is light gray for the most part, very fine to fine grained, and silty, but some is medium dark gray or greenish gray. Dark-gray to black grains, commonly called sporbo, are found in a few sandstone beds near the base of the zone. Some of the sandstone appears to be fairly porous; one bed, 140 feet below the top, may be partly oil stained. The B zone apparently includes a few thin beds of brownish-gray very fine grained argillaceous dolomite; these beds may be logged from caved or recirculated samples.

A few microfossils were found in several samples from the B zone by R.S. Beck (written commun., 1969). He identified the foraminifers Haplophragmoides sp., Bathysiphon sp., Globigerina bulloides, Uvigerina(?) sp., Gyroidina rotundimargo (table 2), diatoms including Coscinodiscus sp., and spherical Radiolaria.

The upper contact of the B zone is defined by an upward lithologic change from siltstone to fairly soft gray shale. Changes in the character of the electrical log at the contact are less pronounced than for some of the other contacts; the lithologic change is suggested mainly by the spontaneous-potential curve (pl. 1).

The A zone is 315 feet thick in well 526-30R, where it consists of diatomaceous siltstone interbedded with shale and small amounts of sandstone and dolomite. Rocks of this zone are very similar to those in the B zone. The siltstone is partly dolomitic in the lower half and partly sandy in the upper half. The very fine grained sandstone is found in a few beds about 1-4 feet thick. Except for the uppermost bed, the porosity of the sandstone appears to be low.

Microfossils are fairly common in some beds in the lower half of the A zone but rare in the upper half. From this zone, R. S. Beck (written commun., 1969) identified the foraminifers Haplophragmoides sp., Bolivina cf. B. vaughani(?), Bathysiphon sp. (table 2), the diatom Coscinodiscus sp., and spherical Radiolaria.

The top of the A zone lies within a sequence of interbedded diatomaceous siltstone and shale. The contact with the overlying rocks is defined primarily by the character of the spontaneous-potential curve of the electrical log (pl. 1). The top of the Antelope Shale of the Unit Operator lies about 78 feet below the top of the A zone (R. D. Carter, J. C. Maher, and R. J. Lantz, written commun., 1969).

The N zone, 710 feet thick, forms the uppermost subdivision of the Elk Hills Shale Member. This zone consists predominantly of diato- 
maceous siltstone and lesser amounts of shale and sandstone. Although these rocks are very similar to those in underlying zones, siliceous rocks are somewhat less common. The siltstone generally varies in color from pale yellowish brown to brownish gray; it may also be light to dark gray, yellowish gray, and very pale orange. Very thin dark-gray streaks are abundant in many beds. Diatomaceous siltstone units 20 feet or more thick are more common in the $\mathrm{N}$ zone than in the other zones. The shale is brownish gray, dusky brown, dark gray, silty, and partly siliceous. The sandstone is medium light to medium dark gray or partly greenish gray, very fine to medium grained, and silty or clayey. Accessory minerals found in some of the sandstone include mica, feldspar, pyrite, and black rounded grains. Most sandstone beds are about 3 feet thick; the greatest thickness is 8 feet. The sandstone in several beds appears to be fairly porous, and three beds are partly oil stained. The $\mathrm{N}$ zone includes a few thin beds of pale-yellowish-brown to brownish-gray argillaceous or siliceous dolomite and, in the lower-middle part, some dusky-brown to brownish-black dense chert. The chert probably occurs in a bed, about 3 feet thick, that overlies very siliceous diatomaceous siltstone.

Pelecypod fragments were found in several sandstone beds in the $\mathrm{N}$ zone, and one sandstone bed in the upper part contained gastropods. Fragments of fish bones also occur in the zone. Microfossils identified by R. S. Beck (written commun., 1969) include Haplophragmoides sp., Ammobaculites sp., Cyclammina sp. (table 2), Coscinodiscus sp., sponge spicules, and spherical Radiolaria. In most samples studied by Beck, Haplophragmoides sp. was common, but the other microfossils were scarce.

Two electrical-log markers, called the $\mathrm{Q}$ and $\mathrm{N}$ points by the Unit Operator, lie within the $\mathrm{N}$ zone. These markers are called horizons in this report (pl. 1). In the lower part of the zone the $Q$ horizon is persistent only in the western part of the Elk Hills oil field (J. C. Maher, R. D. Carter, and R. J. Lantz, written commun., 1970); near the top of the zone the $\mathrm{N}$ horizon extends through most of the field. The $\mathrm{N}$ horizon has for many years been used extensively as a datum in studies of oil fields east of Elk Hills.

The upper contact of the $\mathrm{N}$ zone marks the top of the Elk Hills Shale Member; it also separates the Monterey Shale from the overlying Reef Ridge Shale. This contact in well 526-30R is defined by an upward lithologic change from brown siliceous shale to gray partly sandy shale that is not siliceous. The microfauna in the upper part of the Monterey and the lower part of the Reef Ridge provide no assistance in determining the position of the contact. The lithologic change at the contact is suggested by a change in the resistivity of the strata (pl. 1). 


\section{REEF RIDGE SHALE}

The name Reef Ridge Shale was proposed by Barbat and Johnson (1933, p. 239; 1934, p. 3-5) for a distinctive soft blue (brown weathering) clay shale poorly exposed on the northeast side of Reef Ridge, stratigraphically above the brown siliceous shale of the McLure Shale Member. These workers noted that the distinctive character of the strata was first recognized by Arnold and Anderson (1910, p. 92), who included the rocks as an upper division of the Santa Margarita(?) Formation near the southeast end of Reef Ridge but mapped equivalent rocks along the northwest end of Reef Ridge as a transition zone assigned to the overlying Jacalitos Formation. Barbat and Johnson (1934, p. 4) believed that their Reef Ridge Shale was not included in the McLure Shale by Henny (1930, p. 403-410), who applied the term "McLure" to the brown, mostly siliceous shale in the Coalinga region. As originally defined, the Reef Ridge Shale included, in the lower part, brown clayey and silty shale that Henny (1930) had included in the McLure; for this reason, Siegfus (1939, p. $31,32,43)$ restricted the Reef Ridge to the gray shale overlying the brown shale of the McLure.

In a study of the Coalinga region, Adegoke (1969,p. 19-21) ranked the Reef Ridge and underlying McLure as members of the Monterey Shale and suggested that distinction based on color alone is likely to be erroneous because the color of the Reef Ridge differs from place to place. He described the shale of the Reef Ridge as brownish at the base where it grades downward into the McLure, light blue to purplish gray in most of the overlying beds, and rusty brown and sandy in the upper part which grades into brown sandstone of the overlying Etchegoin Formation (Adegoke, 1969, p. 21).

The age of the upper part of the Reef Ridge Shale in the type area has been controversial for many years. Barbat and Johnson (1934, p. 11) regarded the Reef Ridge as latest Miocene in age on the basis of stratigraphic relations and faunal content and correlated the formation with the upper part of the Monterey Shale. On the basis of stratigraphic position, they suggested $(1934$, p. 9) a correlation between the Reef Ridge and the upper diatomite member (Belridge Diatomite of Siegfus, (1939)) of the Monterey ("Maricopa") on Chico Martinez Creek and credited P. P. Goudkoff with finding Foraminifera of Reef Ridge affinities in the diatomite. Dibblee (1973) believes the Belridge Diatomite Member is older than the Reef Ridge Shale.

In a study of the Kettleman Hills oil field, Goudkoff (1934, p. 439, 473) considered the microfauna in the upper part of the Reef Ridge to be closely related to that in the overlying Jacalitos Formation of Pliocene age. Siegfus $(1939$, p. 37,44$)$ questioned the chronologic 
significance of the shallow-water Foraminifera in the Jacalitos, although he assumed the age of the upper part of the Reef Ridge is generally transitional between the Miocene and Pliocene. Woodring, Stewart, and Richards (1940, p. 121) considered the age of the Reef Ridge Shale to be late Miocene; they based their conclusion on R. M. Kleinpell's opinion that the Foraminifera from this formation have Miocene affinities.

In areas far from the type area, the age of the upper part of the Reef Ridge Shale is even more controversial. Difficulties in correlation arise from lateral changes in lithology, thickness, and faunal content. As pointed out by Foss and Blaisdell $(1968$, p. 34$)$, geologists are not in general agreement on rocks assignable to the formation.

The Reef Ridge Shale in well 526-30R has a drilled thickness of 578 feet. A dipmeter survey indicates that the rocks generally dip about $15^{\circ}-45^{\circ}$ and the direction of dip is mostly northeast to east. However, the amount and direction of dip, as recorded by the dipmeter, varies so widely within closely spaced vertical intervals that the accuracy of much of the data seems uncertain. The deviation of the well bore through the Reef Ridge is about $2^{\circ}-4^{\circ}$; the direction of deviation is west to northwest. The true thickness is about 530 feet.

The Reef Ridge Shale consists almost entirely of shale in well 526$30 \mathrm{R}$, but the formation includes a few thin beds of siltstone, sandstone, and dolomite. The shale is mostly dark gray and olive gray; some shale in the lower third is grayish black. The shale is silty or partly sandy and some of it contains thin stringers or lenses of sandstone. A few beds of siliceous shale are found mainly in the middle and lower parts. The siltstone is mostly olive gray to brownish gray and sandy. The sandstone, in beds as much as 3 feet thick, is medium to dark gray, very fine to fine grained, and mostly very silty or clayey. One sandstone bed near the middle of the formation may be oil stained in part. The dolomite is mostly pale to moderate yellowish brown, very fine grained to dense, very argillaceous, and hard. Coal or lignite probably occurs in one or more very thin beds or lenses near the middle of the formation. The stratigraphic position of the coal is uncertain because well samples from the formation contained only a few coal fragments at most. These fragments might have caved from a thin undetected coal bed in the overlying Pliocene rocks.

Fossils are generally rare in the Reef Ridge Shale in well 526-30R, and no diagnostic microfossils were found by R. S. Beck (written commun., 1969). The only foraminifer he identified is Haplophragmoides sp. (table 2), which occurs, at least rarely, throughout the formation. In some samples Beck found a few diatoms, Radiolaria, and fragments of mollusks and fish bones. A sample near the base contained a few specimens of Coscinodiscus sp. 
An electrical-log marker, called the $\mathrm{F}$ horizon ( $\mathrm{F}$ point of Unit Operator), lies near the middle of the Reef Ridge Shale (pl. 1). This marker is recognized in the western part of the Elk Hills oil field, but its eastward extent is uncertain.

The contact between the Reef Ridge Shale and the overlying Etchegoin Formation is difficult to determine in many wells in the Elk Hills field. In several wells about 2 miles west of well 526-30R, the Reef Ridge is overlain by a sandstone unit, several hundred feet thick, called the Olig sand zone (J. C. Maher, R. D. Carter, and R. J. Lantz, written commun., 1969). This zone includes some interbedded shale, especially in the lower part. Eastward the shale becomes the dominant lithology; the individual sandstone beds pinch out or grade into shale. The contact between the Reef Ridge and the Etchegoin in well 526-30R was determined by J. C. Maher, R. D. Carter, and R. J. Lantz (written commun., 1969), who made detailed electrical-log correlations between this well and those to the west, where the Olig sand zone is very thick and is predominantly sandstone.

In well 526-30R the contact between the Reef Ridge Shale and the Etchegoin Formation is placed at the base of a thin fine-grained sandstone (pl. 1) that is approximately equivalent to the lowermost sandstone in the Olig sand zone to the west. Rocks above the contact constitute a shale unit 157 feet thick that is overlain by a thick sandstone called the Olig sand. This sandstone is approximately equivalent to the upper part of the Olig sand zone in wells to the west (J. C. Maher, R. D. Carter, and R. J. Lantz, written commun., 1969). Rocks of the shale unit generally resemble the strata in the upper part of the Reef Ridge except that siliceous shale and brownish-gray shale are more common above the formation contact. The general similarity of the rocks suggests that the contact may be gradational in well 526-30R. Some geologists would include the shale unit in the Reef Ridge and place the upper contact at the base of the Olig sand.

\section{POST-MIOCENE ROCKS}

A reference section for subsurface Pliocene rocks at Elk Hills was described by Berryman (1973) for well 324-19R, located about a mile north of well 526-30R. The Pliocene and Pleistocene rocks in well 526-30R are described briefly below and in detail in the following section.

The Pliocene Etchegoin Formation, 2,637 feet thick in well 526$30 \mathrm{R}$, is divided into the Tupman Shale Member and the overlying Carman Sandstone Member (pl. 1), named and described by Berryman (1973) following unpublished work by J. C. Maher, R. D. Carter, and R. J. Lantz (written commun., 1970). The Tupman Shale Member is 1,347 feet thick in well $526-30 \mathrm{R}$, where it consists of shale and 
some interbedded siltstone and sandstone. The member is divided into the informal Olig sand zone and the overlying Buliminella silt zone. The Olig sand zone, 224 feet thick, includes the Olig sand in the upper part. The Olig sand consists of fine- to coarse-grained feldspathic sandstone 67 feet thick. A mile north, the Olig sand is absent in well 324-19R, the type section for the Tupman. Some geologists place the boundary between Miocene and Pliocene rocks at the base of the Olig sand; others consider the Olig as the upper part of the Miocene (Foss and Blaisdell, 1968, p. 34, 37). The middle part of the Tupman includes several sandstone beds, and the top of one of these, as delineated by the electrical log, is called the $\mathrm{O}$ horizon (pl. 1). This electrical-log marker is readily identified in much of the Elk Hills field.

The Carman Sandstone Member is 1,290 feet thick in well 526$30 \mathrm{R}$, where it is divided into four informally named zones; in upward order, they are the Calitroleum, Gusher, Wilhelm, and Mulina sand zones (pl. 1). Each zone includes several sandstone beds separated by shale or siltstone. The numerous infomally named "oil sands" within these zones are not identified in well 526-30R because detailed correlation of many electrical logs for wells in the western part of the Elk Hills oil field strongly suggests most "oil sands" are lenses of limited extent (R. D. Carter, J. C. Maher, and R. J. Lantz, written commun., 1969). The top of the Etchegoin Formation is difficult to recognize in well 526-30R; it was determined by correlation of the Mulinia electrical-log horizon from other wells (R. D. Carter, J. C. Maher, and R. J. Lantz, written commun., 1969).

The San Joaquin Formation, of Pliocene age, is 1,540 feet thick in well 526-30R, where it is divided into the informal Scalez sand zone and the overlying Mya sand zone. In this well the Scalez sand zone, 255 feet thick, consists predominantly of shale and includes, in the lower part, the Scalez electrical-log horizon. The Mya sand zone, 1,285 feet thick, also consists largely of shale. Sandstone and siltstone, in beds as much as $\mathbf{1 5}$ feet thick, make up a small part of the zone. In well 324-19R, about a mile to the north, the middle and upper parts of the San Joaquin include somewhat more sandstone and siltstone (Berryman, 1973). The upper contact of the formation is marked by a pronounced lithologic change from shale to poorly sorted feldspathic sandstone, and this contact is readily identified on the electrical log (pl. 1).

The Tulare Formation, of Pliocene and Pleistocene age, is chiefly sand and poorly consolidated sandstone. This formation, 1,280 feet thick in well 526-30R, is divided into a lower sand and gravel member, a clay member, and an upper sand and gravel member in accordance with the classification of R. D. Carter, R. J. Lantz, and J. C. Maher (written commun., 1969). 
The lower sand and gravel member of the Tulare Formation, 567 feet thick in well 526-30R, consists of sand and sandstone interbedded with siltstone and shale. Grain size of the sand and sandstone varies from very fine to very coarse; some sand in the upper part contains granules. Some sandstone and siltstone in the lower part of the member was abundantly oil stained (pl. 1).

The clay member, in the middle of the Tulare, is 91 feet thick and consists chiefly of silty to sandy shale and some fine to coarse sand. This member is rather well delimited by electrical-log characteristics (pl. 1).

The upper sand and gravel member of the Tulare, 622 feet thick, is predominantly feldspathic sand; samples are missing for the upper 117 feet. Grain size of the sand varies from fine to very coarse, and much of the sand contains granules. A small part of the upper member consists of sandy siltstone and partly sandy shale, that may be more accurately described as poorly consolidated clay, claystone, or mudstone.

\section{REFERENCES CITED}

Adegoke, O. S., 1969, Stratigraphy and paleontology of the marine Neogene formations of the Coalinga region, California: California Univ. Pubs. Geol. Sci., v. 80, 269 p.

Anderson, F. M., 1905, A stratigraphic study in the Mount Diablo range of California: California Acad. Sci. Proc., 3d ser., Geology, v. 2, no. 2, p. 155-248.

1908, A further stratigraphic study in the Mount Diablo range of California: California Acad. Sci. Proc., 4th ser., v. 3, no. 1, p. 1-40.

Arnold, Ralph, 1909, Paleontology of the Coalinga district, Fresno and Kings Counties, California: U.S. Geol. Survey Bull. 396, 173 p.

Arnold, Ralph, and Anderson, Robert, 1910, Geology and oil resources of the Coalinga district, California: U.S. Geol. Survey Bull. 398, 354 p.

Bailey, W. C., 1939, Wasco oil field [Calif.]: California Oil Fields, v. 24, no. 3, p. 66-71.

Bandy, O. L., and Arnal, R. E., 1969, Middle Tertiary basin development, San Joaquin Valley, California: Geol. Soc. America Bull., v. 80, no. 5, p. 783-819.

Barbat, W. F., 1932, Age of producing horizon at Kettleman Hills, California: Am. Assoc. Petroleum Geologists Bull., v. 16, no. 6, p. 611-612.

Barbat, W. F., and Johnson, F. L., 1933, Stratigraphy and Foraminifera of the Reef Ridge shale, upper Miocene, California [abs.]: Pan-Am. Geologist, v. 59 , no. 3, p. 239.

1934, Stratigraphy and Foraminifera of the Reef Ridge shale, upper Miocene, California: Jour. Paleontology, v. 8, no. 1, p. 3-17.

Berryman, W. M., 1973, Lithologic characteristics of Pliocene rocks cored at Elk Hills, Kern County, California: U.S. Geol. Survey Bull. 1332-D (in press).

Blake, W. P., 1855, Notice of remarkable strata containing the remains of Infusoria and Polythalamia in the Tertiary formation of Monterey, California: Acad. Nat. Sci. Philadelphia Proc., v. 7, p. 328-331.

Bode, F. D., 1935, The fauna of the Merychippus zone, North Coalinga district, California: Carnegie Inst. Washington Pub., no. 453, p. 67-86.

Church, H. V., Jr., and others, 1957, Cenozoic correlation section across south San Joaquin Valley from San Andreas fault to Sierra Nevada foothills, 
California: Los Angeles, Am. Assoc. Petroleum Geologists, Pacific Sec.

Clark, L. M., and Clark, Alex, 1935, The Vaqueros in the Temblor Range [abs.]: Am. Assoc. Petroleum Geologists Bull., v. 19, no. 1, p. 137.

Cunningham, G. M., and Barbat, W. F., 1932, Age of producing horizon at Kettleman Hills, California: Am. Assoc. Petroleum Geologists Bull., v. 16, no. 4, p. 417-421.

Curran, J. F., 1943, Eocene stratigraphy of Chico Martinez Creek area, Kern County, California: Am. Assoc. Petroleum Geologists Bull., v. 27, no 10, p. 1361-1386.

Cushman, J. A., and Barbat, W. F., 1932, Notes on some arenaceous Foraminifera from the Temblor formation of California: Cushman Lab. Foram. Research Contr., v. 8, pt. 2, no. 119, p. 29-40.

Cushman, J. A., and Goudkoff, P. P., 1938, A new species of Pulvinulinella from the California Miocene: Cushman Lab. Foram. Research Contr., v. 14, pt. 1, no. 192, p. 1-2.

Dibblee, T. W., Jr., compiler, 1968, Geologic map of Temblor Range, San Luis Obispo and Kern Counties, California, in Guidebook, geology and oil fields, west side southern San Joaquin Valley: Am. Assoc. Petroleum GeologistsSoc. Explor. Geophysicists-Soc. Econ. Paleontologists and Mineralogists, Pacific Secs. Guidebook 43d Ann. Mtg., Bakersfield, Calif. Mar. 1968, map. 1973, Stratigraphy of the Southern Coast Ranges near the San Andreas fault from Cholame to Maricopa, California: U.S. Geol. Survey Prof. Paper 764, (in press).

Eldridge, G. H., 1903, The petroleum fields of California, in Contributions to economic geology, 1902: U.S. Geol. Survey Bull. 213, p. 306-321.

Elk Hills Engineering Committee, 1957, Stevens zone, estimated recoverable oil and second revision of percentage participations as of November 20, 1942, in Unit operation-Naval Petroleum Reserve No. 1 (Elk Hills), Kern County, California: Bakersfield, Calif., Elk Hills Eng. Comm., 42 p., 1 fig., 22 maps.

English, W. A., 1916, Geology and oil prospects of Cuyama Valley, California, in Contributions to economic geology, 1915: U.S. Geol. Survey Bull. 621, p. 191-215.

1918, Geology and oil prospects of the Salinas Valley-Parkfield area, California: U.S. Geol. Survey Bull. 691, pt. 2, p. 219-250.

Fairbanks, H. W., 1904, Description of the San Luis quadrangle [California]: U.S. Geol. Survey Geol. Atlas, Folio 101, 14 p.

Foss, C. D., and Blaisdell, Robert, 1968, Stratigraphy of the west side southern San Joaquin Valley, in Guidebook, geology and oil fields, west side southern San Joaquin Valley: Am. Assoc. Petroleum Geologists-Soc. Explor. Geophysicists-Soc. Econ. Paleontologists and Mineralogists, Pacific Secs., Guidebook 43d Ann. Mtg., Bakersfield, Calif., Mar. 1968, p. 33-43.

Gester, G. C., and Galloway, John, 1933, Geology of Kettleman Hills oil field, California: Am. Assoc. Petroleum Geologists Bull., v. 17, no. 10, p. 11611193.

Goddard, E. N., chm., and others, 1948, Rock-color chart: Washington, D.C., Natl. Research Council, repr. Geol. Soc. America, 1963.

Goudkoff, P. P., 1931, Age of producing horizon at Kettleman Hills, California: Am. Assoc. Petroleum Geologists Bull., v. 15, no. 7, p. 839-842.

1934, Subsurface stratigraphy of Kettleman Hills oil field, California: Am. Assoc. Petroleum Geologists Bull., v. 18, no. 4, p. 435-475.

1941, Correlation of oil field formations on west side of San Joaquin Valley [Calif.], in Geologic formations and economic development of the 
oil and gas fields of California; part 2, Geology of California and the occurrence of oil and gas: California Dept. Nat. Res. Div. Mines Bull. 118 preprint, p. 247-252.

Hamlin, Homer, 1904, Water resources of the Salinas Valley, California: U.S. Geol. Survey Water-Supply Paper 89, 91 p.

Hanna, G. D., 1928, The Monterey shale of California at its type locality with a summary of its fauna and flora: Am. Assoc. Petroleum Geologists Bull., v. 12 , no. 10 , p. 969-983.

Heikkila, H. H., and MacLeod, G. M., 1951, Geology of Bitterwater Creek area, Kern County, California: California Div. Mines Spec. Report 6, 21 p.

Henny, Gerard, 1930, McLure shale of the Coalinga region, Fresno and Kings Counties, California: Am. Assoc. Petroleum Geologists Bull., v. 14, no. 4, p. $403-410$.

Kleinpell, R. M., 1938, Miocene stratigraphy of California: Tulsa, Oklahoma, Am. Assoc. Petroleum Geologists, 450 p., repr. 1955.

Lawson, A. C., 1893, The geology of Carmelo Bay [Calif.]: California Univ. Dept. Geology Bull., v. 1, no. 1, p. 1-59.

Loel, Wayne, and Corey, W. H., 1932, The Vaqueros formation, lower Miocene of California, pt. 1, Paleontology: California Univ., Dept. Geol. Sci. Bull., v. 22 , no. 3, p. 31-410.

Lorshbough, A. L., 1967, Western portion of Elk Hills oil field [Calif.]: California Oil Fields, v. 53, no. 1, p. 33-37.

Louderback, G. D., 1913, The Monterey series in California: California Univ., Dept. Geology Bull., v. 7, no. 10, p. 177-241.

Maher, J. C., 1959, The composite interpretive method of logging drill cuttings: Oklahoma Geol. Survey Guidebook 8, 48 p.; 2d ed. 1964 as Guidebook 14.

Martin, Bruce, 1912, Fauna from the type locality of the Monterey Series in California: California Univ., Dept. Geology Bull., v. 7, no. 7, p. 143-150.

Merriam, J. C., 1915, Tertiary vertebrate faunas of the north Coalinga region of California: Am. Philos. Soc. Trans., v. 22, pt. 3, p. 1-44.

Noble, E. B., 1940, Rio Bravo oil field, Kern County, California: Am. Assoc. Petroleum Geologists Bull., v. 24, no. 7, p. 1330-1333.

Pack, R. W., 1920, The Sunset-Midway oil field, California; Part 1, Geology and oil resources: U.S. Geol. Survey Prof. Paper 116, 179 p.

Park, W. H., and Land, P. E., 1955, Correlation sections of west side fields of Kern County [Calif.]: California Oil Fields, v. 41, no. 1, p. 32, 7 pls.

Reed, R. D., 1933, Geology of California: Tulsa, Oklahoma, Am. Assoc. Petroleum Geologists, 355 p., repr. 1951.

San Joaquin Geological Society, 1959, Guidebook, Chico Martinez Creek area, field trip [Calif.]: San Joaquin Geol. Soc., May 9, 1959, 15 p.

Schenck, H. G., 1935, What is the Vaqueros formation of California and is it Oligocene?: Am. Assoc. Petroleum Geologists Bull., v. 19, no. 4, p. 521-536.

Siegfus, S. S., 1939, Stratigraphic features of Reef Ridge shale in southern California: Am. Assoc. Petroleum Geologists Bull., v. 23, no. 1, p. 24-44.

Simonson, R. R., and Kreuger, M. L., 1942, Crocker Flat landslide area, Temblor Range, California: Am. Assoc. Petroleum Geologists bull., v. 26, no. 10 , p. $1,608-1,631$.

Wells, J. C., 1952, Elk Hills field [Calif.], in Guidebook, field trip routes, geology, oil fields: Am. Assoc. Petroleum Geologists-Soc. Econ. Paleontologists and Mineralogists-Soc. Explor. Geophysicists, Pacific Secs., Guidebook Joint Ann. Mtg., Los Angeles, Calif., March 1952, p. 241-245.

Wiedey, L. W., 1928, Notes on the Vaqueros and Temblor formations of the California Miocene with descriptions of new species: San Diego Soc. Nat. 
History Trans., v. 5, no. 10, p. 95-182.

Williams, R. N., Jr., 1936, Recent developments in the North Belridge oil field [California]: California Oil Fields, v. 21, no. 4, p. 5-16.

Woodring, W. P., Stewart, Ralph, and Richards, R. W., 1940, Geology of the Kettleman Hills oil field, California; stratigraphy, paleontology, and structure: U.S. Geol. Survey Prof. Paper 195, 170 p.

\section{DETAILED DESCRIPTION OF LITHOLOGY WELL 526_30R}

[1,650 ft north, $990 \mathrm{ft}$ east of SW. cor. sec. 30, T. 30 S., R. 23 E.]

Quaternary and Tertiary Systems:

Altitude (drill floor) 1,261 feet

Pleistocene and Pliocene Series:

Tulare Formation:

Upper sand and gravel member:

No samples

One sample. Sand, medium to very coarse, subangular; scattered chert and magnetite grains. Much lostcirculation material

Sand, fine to very coarse, subangular to angular; scattered granules and fragments of white chert, feldspar, and light-gray very fine grained limestone ..

Sand, as above; scattered fragments of granite, quartzite, and other hard rocks

Sand, fine to very coarse, mostly coarse to very coarse, subangular to angular; some fragments of white to gray chert, feldspar, and dark-gray to green rock ......

Sand, as above; more fine to medium grains than unit above

Sand, medium to very coarse, subangular to angular; more granules than unit above; fragments of feldspar, chert, and igneous rocks

Shale, moderate-yellowish-brown

Sandstone, light-gray, very fine grained, limy, micaceous

Sand, medium to very coarse, subangular; feldspar fragments

Shale, as above

Sand, as above; few granules, scattered white chert fragments

Siltstone, light-greenish-gray, very finely sandy, micaceous

Sand, medium to very coarse, subangular; granules common, feldspar grains; scattered grains of green, purple, and dark-gray rock and white chert

Shale, light-olive-gray to moderate-yellowish-brown, slightly limy; 2 -ft sand bed in middle

Sand, as above

Shale, moderate yellowish-brown (indicated by mud balls in sample)

Estimated sample lag-20 ft.

Sand, as above 
Quaternary and Tertiary Systems-Continued

Pleistocene and Pliocene Series-Continued

Tulare Formation-Continued

Depth

Upper sand and gravel member-Continued

Sand, medium to very coarse; abundant granules and small pebbles of many rock types; feldspar fragments

Sand, as above; probably no pebbles

$375-395$

$395-406$

Shale, light-olive-gray. Probably contains scattered grains of fine to medium sand

$406-410$

$410-435$

Sand, medium to very coarse; scattered pebbles

$435-460$ granules, feldspar grains

Sand, fine to very coarse, subangular; scattered granules, feldspar grains. Upper half probably includes beds of light-olive-gray sandy siltstone

Sand, fine to very coarse, subangular; feldspar grains and other rock fragments; greenish-gray to olive-gray clay and silt matrix

Sand, medium to very coarse; some granules; olive-gray silty matrix in part; fragments of white chert, feldspar, and other rocks in part; tightly cemented with calcite in part (in 530-545 sample)

$515-550$

Siltstone, light-olive-gray, very finely to finely sandy. Near middle a 3-ft bed of fine to coarse subangular feldspathic silty sand

Sand, medium to very coarse, subangular; few granules, feldspar fragments; trace of pyrite

$564-580$

Sand, as above; probably much greenish-gray silty clay matrix

$580-593$

Sand, medium to very coarse, subangular; feldspar fragments

Sand, as above; probably much gray to greenish-gray silty clay matrix

$604-610$

Sand, fine to coarse, scattered very coarse grains, subangular; feldspar fragments

$610-622$

Clay member:

Shale, light-olive-gray, silty, slightly dolomitic, finely to medium sandy in part; stringers of fine to medium very argillaceous sand

$622-645$

$645-647$

Sand, as above

Shale, as above. Trace of light-gray very fine grained argillaceous limestone (found in 670-685 sample)

$647-665$

$665-668$

Shale, light-olive-gray, slightly dolomitic, sandy in part. One small gastropod (found in 685-700 sample)

$668-685$

Shale, light-olive-gray to greenish-gray, limy in small part, silty

$685-713$

Lower sand and gravel member:

Sand, fine to coarse, some very coarse grains and granules; few fragments of feldspar and white chert. Probably includes a thin bed of fine- to mediumgrained pyritic sandstone

Estimated sample lag-10 ft. 
Quaternary and Tertiary Systems-Continued

Pleistocene and Pliocene Series-Continued

Tulare Formation-Continued

Lower sand and gravel member-Continued

Shale, light-olive-gray, silty

Depth

(ft)

Sand, as above

730-733

733-739

Shale, light-olive-gray, silty, slightly limy. Gastropods abundant in part

$739-750$

Siltstone, light-olive-gray to medium-light-gray, very finely to finely sandy, limy in part

$750-760$

Shale, medium-gray, silty

760-768

Sand fine to coarse, some very coarse grains and few granules; few grains of feldspar and white chert

Sand, fine to coarse, subangular, limy in part

768-785

785-790

Siltstone, medium-light-gray, very finely to finely sandy, slightly limy, fairly soft

790-799

Sandstone, medium-light-gray, very fine to mediumgrained, silty, soft, “dirty”. A 4-ft bed of light-olivegray silty shale in middle

Shale, light-olive-gray to medium-gray, silty

$810-818$

Sandstone, medium-light-gray, very fine to mediumgrained, scattered coarse grains; some feldspar; trace of mica. Probably good porosity

818-848

$848-856$

Shale, light-olive-gray, silty

$856-865$

Sandstone, light-gray, very fine to medium-grained, some coarse grains; includes pyrite, feldspar, and biotite. Clean, free drilling

865-875

Shale, as above

$875-880$

Sandstone, as above; probably very silty in part;

includes several thin shale beds as above

880-914

Shale, as above

914-917

Sandstone, light-olive-gray, very fine to mediumgrained, probably very silty

917-921

Sand, light-gray, very fine to medium, scattered coarse grains; fragments of feldspar and some biotite and pyrite

$921-930$

Shale, light-olive-gray, silty; interbedded with sandstone as above

930-937

937-949

Sandstone, as above

949-954

Shale, as above

954-966

Shale, light-olive-gray, silty; interbedded with some sandstone as above

966-983

983-990

Sandstone, as above

990-1,007

Siltstone, light-olive-gray, finely sandy

$1,007-1,015$

Sandstone, light-gray to light-olive-gray, very fine to medium-grained

$1,015-1,020$

$1,020-1,027$

Siltstone, as above

$1,027-1,035$

Siltstone, as above; interbedded with some sandstone as above 
Quaternary and Tertiary Systems-Continued

Pleistocene and Pliocene Series-Continued

Tulare Formation-Continued

Depth

(ft)

Lower sand and gravel member-Continued

Shale, light-olive-gray; interbedded with sandstone as above

Sandstone, light-gray, fine- to medium-grained, some coarse grains, subangular; some mica, feldspar, and pyrite. Free drilling

Shale, as above; interbedded with sandstone as above..

Shale, medium-gray to greenish-gray, silty

Sandstone, as above; interbedded with olive-gray silty shale

Sandstone, light-gray, fine- to medium-grained, some coarse grains, subangular; few fragments of mica, feldspar, and pyrite. Free drilling

Shale, pale-yellowish-brown

Sandstone, light-olive-gray, very fine to fine-grained, very silty; some biotite; trace of fossil fragments

$1,127-1,130$

Sandstone, as above; many dark-gray ostracods; probably some fine- to medium-grained sandstone ....

Siltstone, light-olive-gray, very sandy, slightly limy to limy. A 3-ft bed of light-olive-gray very fine to fine-grained sandstone at 1,145-1,148

$1,083-1,089$

$1,089-1,095$

$1,095-1,107$

$1,107-1,120$

$1,130-1,138$

1,138-1,159

$1,159-1,164$

Shale, light-olive-gray, silty

Sandstone, light-olive-gray, very fine to mediumgrained, some coarse grains, slightly limy, very silty in part. Sidewall cored at 1,166 and 1,169

Siltstone, greenish-gray, micaceous, slightly limy

Sandstone, greenish-gray, very fine to mediumgrained, scattered coarse grains, micaceous, silty ......

Siltstone, greenish-gray to light-olive-gray, micaceous. Sidewall cored at 1,173

Siltstone, greenish-gray, micaceous; interbedded with oil-stained very fine to fine-grained silty sandstone including scattered medium and coarse grains.

Sidewall cored at 1,176

Sandstone, brownish-gray (oil-stained), very fine to medium-grained, some coarse grains and granules. Free drilling. Sidewall cored at 1,179,1,183, and 1,188

Sandstone, brownish-gray (oil-stained), silty, very fine to very coarse grained; trace of granules; oil odor ......

Sandstone, brownish-gray (oil-stained), fine- to very coarse grained; good porosity; oil odor

Sandstone, brownish-gray (oil-stained), fine-grained, well sorted; fair porosity; oil odor

Siltstone, greenish-gray to light-olive-gray, clayey; few thin-shelled pelecypods and ostracods. Poor samples. Sidewall cored at 1,193, 1,197, 1,201, 1,209

Siltstone, light-olive-gray, oil stained, micaceous

Siltstone, as above. No fossils 
Quaternary and Tertiary Systems-Continued

Pleistocene and Pliocene Series-Continued

Tulare Formation-Continued

Depth

(ft)

Lower sand and gravel member-Continued

Siltstone, as above; some dark-greenish-gray slightly

limy silty shale

Sandstone, slightly oil-stained, very fine to coarsegrained, very few coarse grains; free drilling.

Sidewall cored at 1,213 and 1,217

$1,210-1,220$

Sandstone, oil-stained, very fine to fine-grained. Good porosity

Siltstone, brownish-gray to slightly oil-stained, very finely sandy, clayey, laminated. Sidewall cored at 1,221

$1,220-1,223$

Shale, medium-gray to light-olive-gray. A 2 - $\mathrm{ft}$ bed of light-olive-gray very fine to medium-grained sandstone near the top and another near the middle ..

Sandstone, fine- to coarse-grained, subangular, silty and clayey. Free drilling

$1,223-1,248$

1,248-1,252

$1,252-1,257$

Sandstone, fine- to coarse-grained, some very coarse grains, subangular; some gray feldspar grains; trace of pyrite. Free drilling

$1,257-1,270$

Sandstone, as above, fewer coarse and very coarse grains. Probably interbedded with light-olive-gray very finely to finely sandy micaceous siltstone

$1,270-1,280$

Tertiary System:

Pliocene Series:

San Joaquin Formation:

Mya sand zone:

Shale, light-olive-gray, silty; few thin-shelled pelecypods

Siltstone, light-olive-gray, very finely to medium sandy, limy; upper half interbedded with shale as above

Shale, light-olive-gray to greenish-gray and medium-dark-gray in lower part

Shale, light-olive-gray, silty, micaceous

Shale, greenish-gray to light-olive-gray, silty to finely sandy

Sandstone, fine- to coarse-grained, subangular, free drilling

Shale, greenish-gray to light-olive-gray; few ostracods and Foraminifera

Sandstone, as above

$1,370-1,372$

Shale, as above; silty in part

$1,372-1,400$

Shale, light-olive-gray to greenish-gray; few thinshelled pelecypods; pelecypods abundant in lower $7 \mathrm{ft}$

Siltstone, light-olive-gray, micaceous; interbedded with shale as above

Shale, as above; many pelecypod fragments may be 
Tertiary System-Continued

Pliocene Series-Continued

San Joaquin Formation-Continued

Mya sand zone-Continued

result of caving.

Siltstone, light-olive-gray, very micaceous; scattered very fine to fine sand

$1,437-1,462$

$1,462-1,476$

Shale, as above; pelecypod fragments may be result of caving.

Siltstone, light-olive-gray, micaceous

1,476-1,495

$1,495-1,503$

Shale, as above; silty in part

$1,503-1,525$

Dolomite, pale-yellowish-brown to light-olive-gray, very fine grained, clayey, hard, almost dense

$1,525-1,526$

Shale, light-olive-gray, silty in lower part ....................

Siltstone, light-olive-gray, micaceous

Shale, light-olive-gray to greenish-gray, silty in part

Dolomite, pale to moderate-yellowish-brown with dark-gray streaks, very fine grained, clayey, hard, almost dense, little pyrite

$1,526-1,545$

$1,545-7,550$

$1,550-1,605$

Shale, greenish-gray, silty in part

$1,605-1,606$

$1,606-1,650$

Siltstone, light-olive-gray, micaceous, probably clayey

$1,650-1,657$

Shale, as above

Dolomite, greenish-gray, very fine grained, clayey ....

Shale, greenish-gray to dark-gray

Siltstone, light-olive-gray, micaceous

Shale, greenish-gray, silty in part

Sandstone, light-gray, very fine to fine-grained, some medium and coarse grains, silty; some gray feldspar and biotite. Free drilling. Sidewall cored at 1,734

$1,657-1,670$

$1,670-1,671$

$1,671-1,680$

$1,680-1,684$

$1,684-1,727$

Estimated sample lag-10 ft.

Shale, greenish-gray, silty, micaceous

$1,727-1,738$

$1,738-1,750$

Shale, greenish-gray, silty in part. May include thin beds of micaceous siltstone. Mostly lost-circulation material in 1,810-1,820 sample

$1,750-1,846$

Siltstone, light-olive-gray, micaceous

$1,846-1,850$

Shale, as above; middle part includes a 4-ft siltstone bed as above

$1,850-1,870$

Siltstone, light-olive-gray, very limy, micaceous, scattered fine to medium grains of sand, hard

$1,870-1,876$

Shale, greenish-gray, silty in part; may include thin siltstone beds

Shale, greenish-gray. Dark-gray to brown plant like fragments at about 1,950

$1,876-1,935$

$1,935-1,967$

Siltstone, light-olive-gray, micaceous, slightly limy; scattered very fine to medium sand grains may be result of caving

$1,967-1,970$

$1,970-1,990$

Sandstone, light-gray, very fine to medium-grained, silty, not limy

Siltstone, medium-light-gray, very finely sandy, 
Tertiary System-Continued

Pliocene Series-Continued

San Joaquin Formation-Continued

Mya sand zone-Continued

micaceous

$1,993-2,000$

Shale, greenish-gray, silty in part; pelecypod fragments in lower part; a 3-ft bed of light-olive-gray micaceous siltstone $5 \mathrm{ft}$ below top

Shale, light-olive-gray, medium-gray and brownishgray, silty in part, very dolomitic in lower $4 \mathrm{ft}$; fish fragments, abundant ostracods in part

Siltstone, light-olive-gray, micaceous, very sandy in part

$2,044-2,050$

Shale, olive-gray to brownish-gray, silty in part; very finely to finely sandy stringers. Lower part contains abundant ostracods, fish fragments, pelecypods ......

Shale, greenish-gray, silty, very finely to finely sandy

Shale, brownish-gray to olive-gray; abundant ostracods

Shale, light-olive-gray to olive-gray, silty in part; few fish fragments may be result of caving

Shale, as above; slickensides

Shale, brownish-gray, silty; abundant finely divided plant fragments

Shale, light-olive-gray to olive-gray, silty

Shale, greenish-gray to olive-gray; pelecypods, fish fragments

Shale, as above; gastropods, ostracods, and fish fragments in upper part

Shale, olive-gray; ostracods. Contains one subrounded granule of gray feldspar

$2,000-2,034$

$2,050-2,078$

$2,078-2,081$

$2,081-2,087$

$2,087-2,115$

2,115-2,133

2,133-2,140

$2,140-2,150$

$2,150-2,160$

$2,160-2,180$

$2,180-2,190$

Shale, as above; abundant ostracods, few fish fragments, and questionable pelecypods

2,190-2,210

Shale, light-olive-gray to olive-gray

$2,210-2,220$

Shale, light-olive-gray, silty, very finely to finely sandy; ostracods

$2,220-2,224$

Siltstone, light-olive-gray, very finely to finely sandy, micaceous; abundant fine carbonaceous fragments; may include scattered medium and coarse quartz and feldspar grains

$2,224-2,230$

Shale, olive-gray; ostracods, questionable pelecypods

$2,230-2,250$

Shale, medium-gray, slight green tint; abundant pelecypod fragments, few fish fragments

Shale, greenish-gray to olive-gray, silty in part; fossil fragments (probably result of caving)

Siltstone, light-olive-gray, micaceous

$2,260-2,286$

$2,286-2,290$

Shale, greenish-gray to olive-gray, silty in part. A 3-ft siltstone bed near middle

Siltstone, light-gray to light-greenish-gray, micaceous, probably laminated to very thin bedded Shale, greenish-gray, silty in part. Probably includes 
Tertiary System-Continued

Pliocene Series-Continued

San Joaquin Formation-Continued

Mya sand zone-Continued

siltstone beds as above

$2,374-2,417$

Siltstone, light-olive-gray to light-gray, very finely sandy in part, micaceous

$2,417-2,426$

Shale, as above

Dolomite, olive-gray, very fine grained, clayey, almost dense

Shale, olive-gray to greenish-gray. Probably includes thin beds of siltstone in middle part. Fossils (gastropods, pelecypods and fish fragments) in shale which may have caved from above

Sandstone, light-olive-gray, very fine to fine-grained, very silty, limy, micaceous; low porosity

Siltstone, light-olive-gray to greenish-gray, micaceous

Shale, light-olive-gray, silty stringers; pelecypods, fish fragments in lower part may be the result of caving

Siltstone, light-olive-gray, micaceous

Shale, light-olive-gray to greenish-gray, silty in part

Shale, medium-gray, slight greenish tint; abundant pelecypods, ostracods

Shale, greenish-gray to light-olive-gray; abundant Foraminifera

Shale, olive-gray, silty in part

Scalez sand zone:

Shale, greenish-gray to medium-gray; abundant pelecypods

Shale, olive-gray to greenish-gray, silty in part

Shale, light-olive-gray, slightly dolomitic in part ......

Shale, light-olive-gray, very silty; few fine to coarse sand grains

Shale, medium-gray, slight greenish tint; abundant pelecypods; ostracods (may be result of caving) ....

Shale, light-olive-gray to greenish-gray, silty in part. Fossils, as above, may have caved

Siltstone, medium-light-gray, micaceous

$2,656-2,660$

$2,660-2,680$

Shale, as above; pelecypods

$2,680-2,688$

Siltstone, medium-light-gray to light-olive-gray, very finely sandy in part, micaceous; pyrite

Shale, light-olive-gray, silty in part

Shale, as above; pelecypods, very small gastropods, few Foraminifera

Shale, as above; pelecypods, ostracods

Shale, light-olive-gray to greenish-gray, silty in part. Fossils, as above, may have caved

Shale, as above; ostracods, pelecypods, Foraminifera (may have caved) 
Tertiary System-Continued

Pliocene Series-Continued

Etchegoin Formation:

Depth

Carman Sandstone Member:

Mulinia sand zone:

Shale, as above

$2,820-2,830$

Shale, light-olive-gray; few gray high-spired gastropods, pelecypods

$2,830-2,845$

Shale, as above, silty; pelecypods, ostracods, few gastropods. Probably interbedded with light-olivegray siltstone

$2,845-2,877$

Sandstone, light-olive-gray, very fine to fine-grained, scattered medium grains, subangular, silty, slightly limy, friable; many black subrounded grains; many pelecypod fragments. Sidewall cored at 2,879

Shale, light-olive-gray, silty in part; pelecypods, gastropods, few Foraminifera. Samples include much fine to coarse loose sand

Shale, greenish-gray; abundant ostracods in part, pelecypods, few Foraminifera

hale, greenish-gray to light-olive-gray; interbedded with greenish-gray to medium-light-gray siltstone in middle part

Sandstone, light-olive-gray, very fine grained, very clayey and silty; many black grains; oil odor.

Sidewall cored at 2,951

Shale, greenish-gray; abundant pelecypods in part; few thin beds of very fine to fine-grained sandstone. Sidewall cored at 2,958

$2,952-2,958$

Siltstone, oil-stained, very finely sandy, clayey in part; few pelecypod fragments

Shale, greenish-gray, very finely to medium sandy; abundant pelecypods

Siltstone, greenish-gray to medium-light-gray

Shale, greenish-gray, silty in part; abundant pelecypod fragments (may have caved)

$2,975-3,014$

Wilhelm sand zone:

Siltstone, greenish-gray, very finely sandy in part ......

Sandstone, light-olive-gray, fine- to medium-grained, very clayey and silty; low porosity. Sidewall cored at 3,031

$3,014-3,030$

$3,030-3,034$

Siltstone, light-olive-gray; interbedded with greenish-gray to light-olive-gray silty shale.

Probably includes thin beds of light-olive-gray very

fine to fine-grained silty limy sandstone with low porosity

Siltstone, medium-light-gray to light-olive-gray, very finely sandy, micaceous

Shale, greenish-gray to light-olive-gray, silty in part; few gastropods, pelecypods (may have caved)

Siltstone, light-olive-gray, very finely sandy in part; interbedded with light-olive-gray very fine grained 
Tertiary System-Continued

Pliocene Series-Continued

Etchegoin Formation-Continued

Depth
$($ ft $)$

Carman Sandstone Member-Continued

Wilhelm sand zone-Continued

silty sandstone

$3,109-3,132$

Shale, greenish-gray, silty in part

$3,132-3,145$

Sandstone, fine- to medium-grained. Free drilling ......

Shale, as above

$3,145-3,148$

$3,148-3,150$

Sandstone, light-olive-gray, fine- to medium-grained, green "clay" grains common, fairly clayey; fairly

good porosity; some oil odor. Sidewall cored at 3,155

Shale, light-olive-gray to greenish-gray, silty in part. Probably includes thin siltstone beds. Samples are mostly loose very fine to medium sand

$3,150-3,160$

Siltstone, medium-light-gray to light-olive-gray, very finely sandy in part

Shale, as above

Siltstone, as above

Shale, as above

Siltstone, as above

Shale, as above

Siltstone, as above

Shale, olive-gray

Siltstone, as above

Sandstone, light-olive-gray, very fine to fine-grained, silty, free drilling

Siltstone, light-olive-gray, very finely sandy

Shale, light-olive-gray, silty

Shale, light-olive-gray to greenish-gray, partly silty in lower half

Gusher sand zone:

Shale, as above, silty

Siltstone, medium-light-gray, very finely sandy ........

Shale, as above

Siltstone, light-olive-gray, very finely to finely sandy

Shale, as above

Siltstone, as above

Shale, as above

Siltstone, light-olive-gray, very finely to medium sandy, about 50 percent sand; scattered dark-green "clay" grains. Sidewall cored at 3,467

Sandstone, light-gray, very fine to medium-grained, very silty; low porosity. Sidewall cored at 3,469

Electrical-log interpretation. No samples from 3,500 to 3,585 . Bottom of $95 / 8^{\prime \prime}$ casing at 3,495

Estimated sample lag-about 20-30 ft.

Sandstone, as above

$3,160-3,206$

$3,206-3,212$

$3,212-3,220$

$3,220-3,227$

$3,227-3,233$

$3,233-3,237$

$3,237-3,248$

$3,248-3,253$

3,253-3,267

$3,267-3,270$

$3,270-3,277$

$3,277-3,289$

$3,289-3,310$

$3,310-3,356$

$3,356-3,367$

$3,367-3,370$

$3,370-3,422$

$3,422-3,430$

$3,430-3,436$

$3,436-3,460$

$3,460-3,464$

Siltstone, as above

Shale, as above; thin siltstone bed near top

Siltstone, as above

Shale, as above

Siltstone, as above

$3,464-3,468$

$3,468-3,470$

$3,470-3,565$

3,470-3,472

3,472-3,477

3,477-3,494

3,494-3,503

3,503-3,517

3,517-3,522 
Tertiary System-Continued

Pliocene Series-Continued

Etchegoin Formation-Continued

Depth

(ft)

Carman Sandstone Member-Continued

Gusher sand zone-Continued

Shale, as above

$3,522-3,530$

Siltstone, as above

$3,530-3,540$

Shale, as above

$3,540-3,565$

Siltstone, light-olive-gray, very finely sandy, micaceous

$3,565-3,568$

Sandstone, light-olive-gray, very fine to fine-grained, very silty, limy, micaceous

3,568-3,570

Siltstone, as above

Shale, light-olive-gray, silty .

$3,570-3,580$

$3,580-3,596$

Siltstone, as above

$3,596-3,599$

Sandstone, fine- to coarse-grained, subangular, probably very silty and soft, micaceous, feldspar fragments; free drilling

Siltstone, light-olive-gray, very finely to medium sandy

Shale, light-olive-gray, silty; few very fine to medium sand grains

$3,599-3,607$

$3,607-3,610$

$3,610-3,617$

$3,617-3,620$

$3,620-3,649$

Shale, light-olive-gray, silty

Dolomite, yellowish-gray to light-olive-gray, very fine grained, silty, clayey, hard

$3,649-3,650$

$3,650-3,657$

$3,657-3,660$

Siltstone, light-olive-gray, very finely to finely sandy

Sandstone, light-olive-gray, very fine to mediumgrained, very silty; pelecypod fragments

$3,660-3,663$

$3,663-3,675$

$3,675-3,694$

Siltstone, light-olive-gray, very finely to finely sandy

Sandstone, fine- to medium-grained, probably very silty and soft; abundant dark-gray to black grains, feldspar, mica. A 2-ft siltstone bed in middle. Free drilling

3,694-3,705

Shale, olive-gray, silty to finely sandy

$3,705-3,715$

Sandstone, very fine to medium-grained, probably very silty and soft; feldspar, mica. Free drilling ......

Shale, olive-gray, silty to finely sandy

$3,715-3,724$

3,724-3,735

Sandstone, fine- to medium-grained, some coarse grains, subangular, probably very silty in part; some feldspar and mica. Free drilling

3,735-3,757

$3,757-3,763$

Shale, olive-gray, silty

Siltstone, light-olive-gray, very finely to medium sandy

$3,763-3,770$

Shale, light-olive-gray, silty to finely sandy

$3,770-3,797$

Sandstone, light-gray, fine-grained, clayey, limy to dolomitic

Shale, as above

$3,832-3,840$

Siltstone, light-olive-gray, very finely to finely sandy

Shale, light-olive-gray, silty to finely sandy

$3,840-3,873$ 
Tertiary System-Continued

Pliocene Series-Continued

Etchegoin Formation-Continued

Carman Sandstone Member-Continued

Calitroleum sand zone:

Sandstone, fine- to medium-grained, scattered coarse grains, probably silty to clayey; few tight limy to dolomitic beds; pelecypod fragments. Mostly free drilling

3,873-3,886

Siltstone, light-olive-gray, very finely to finely sandy ....

$3,886-3,893$

Shale, light-olive-gray, silty

Sandstone, as above

Siltstone, as above; pelecypod fragments

$3,893-3,896$

$3,896-3,900$

$3,900-3,906$

Sandstone, as above; pelecypod fragments

$3,906-3,910$

Siltstone, light-olive-gray, very finely to finely sandy; pelecypod fragments

$3,910-3,925$

Sandstone, as above; pelecypod fragments

$3,925-3,940$

Sandstone, medium-light-gray to light-olive-gray, very fine to fine-grained, silty, dolomitic, tight

$3,940-3,944$

Siltstone, light-olive-gray, very finely to finely sandy in part, dolomitic in part

$3,944-3,953$

Sandstone, light-olive-gray, very fine to fine-grained, very silty; interbedded with light-olive-gray sandy siltstone. Mostly free drilling

$3,953-3,966$

Siltstone and sandstone, as above; pelecypod fragments

Shale, olive-gray to medium-gray, silty

Sandstone, light-olive-gray, very fine to fine-grained, very silty. Dolomitic to limy and hard and tight in lower $4 \mathrm{ft}$; many pelecypod fragments. Mostly free drilling.

Siltstone, light-olive-gray, very finely to finely sandy in part

Sandstone, medium-light-gray, very fine to finegrained, silty, limy, tight

Siltstone, as above

Sandstone, light-olive-gray, very fine to fine-grained, very silty

Siltstone, as above

Sandstone, light-olive-gray, very fine to fine-grained, silty, limy; pelecypod fragments; low porosity

Siltstone, as above

Sandstone, as above

Shale, light-olive-gray, silty; pelecypods

Siltstone, light-olive-gray, dolomitic

Tupman Shale Member:

Buliminella silt zone:

Shale, light-olive-gray to medium-gray, silty in part; pelecypods, few Foraminifera, and ostracods

Dolomite, yellowish-gray to light-olive-gray, very fine grained, very silty 
Tertiary System-Continued

Pliocene Series-Continued

Etchegoin Formation-Continued

Depth

Tupman Shale Member-Continued

Buliminella silt zone-Continued sandy in part, dolomitic in part. Probably includes thin beds of very fine to fine-grained silty friable sandstone with many black rounded grains

Shale, medium-gray, slight greenish tint, silty in part

Siltstone, medium-light-gray

Dolomite, medium-light-gray, very fine grained, clayey to silty

$4,198-4,200$

Shale, greenish-gray, silty

$4,200-4,227$

Shale, medium-gray to greenish-gray, silty in part; few pelecypods

Siltstone, yellowish-gray, very finely sandy, dolomitic

Shale, greenish-gray

Siltstone, light-olive-gray, very finely sandy

Shale, greenish-gray to medium-gray, silty

Sandstone, medium-light-gray, very fine to finegrained, silty, limy; pelecypods

Shale, greenish-gray, silty; pelecypods, few Foraminifera

Dolomite, pale-yellowish-brown, very fine grained, silty to clayey, hard, tight

Shale, medium-gray

Shale, greenish-gray to medium-gray, silty

Sandstone, light-olive-gray to medium-light-gray, very fine to fine-grained, silty, limy, micaceous; low porosity

Shale, greenish-gray, silty in part

Siltstone, light-olive-gray, very finely to finely sandy; pelecypods. Interbedded with shale as above

Siltstone, as above; interbedded with medium-gray silty shale. Samples include loose sand and black grains that may be sporbo

Siltstone, light-olive-gray, very finely to finely sandy

Shale, medium-gray, silty

Siltstone, light-olive-gray, very finely to finely sandy; black rounded grains as above

Shale, greenish-gray, silty

Dolomite, medium-light-gray, very fine grained, silty to clayey; common black phosphatic-looking grains that may be sporbo

Sandstone, medium-gray, very fine grained, silty; abundant black grains

Shale, olive-gray, silty

Siltstone, light-olive-gray, very finely to finely sandy

Siltstone, medium-gray to olive-gray, very finely to finely sandy; some black rounded grains 


\section{Tertiary System-Continued}

Pliocene Series-Continued

Etchegoin Formation-Continued

Tupman Shale Member-Continued

Buliminella silt zone-Continued

Shale, olive-gray to dark-greenish-gray, silty to sandy

Sandstone, very fine to fine-grained, probably silty and clayey. Free drilling. May be caving

Shale, olive-gray, silty

Dolomite, pale-yellowish-brown, very fine grained, silty to clayey, hard, siliceous-looking in part ........

Shale, olive-gray, silty to finely sandy

Shale, olive-gray to medium-dark-gray, silty; probably interbedded with olive-gray sandy siltstone

Siltstone, light-olive-gray, very finely to finely sandy in part

Shale, greenish-gray

Siltstone, medium-gray, very finely to finely sandy ....

Shale, medium-gray, slight greenish tint, silty

$4,564-4,567$

$4,567-4,572$

Shale, olive-gray, silty to finely sandy

Siltstone, medium-gray, very finely to finely sandy ....

Shale, as above

Siltstone, light-olive-gray to medium-gray, very

finely sandy, limy in part; questionable

pelecypods

Dolomite, medium-light-gray, very fine grained, very clayey, silty, hard, tight

$4,572-4,584$

$4,584-4,610$

$4,610-4,614$

$4,614-4,630$

$4,630-4,634$

$4,634-4,636$

Shale, olive-gray, silty to sandy

Sandstone, olive-gray, very fine to fine-grained, silty, probably siliceous cement, hard, tight; scattered dark grains

Shale, medium-dark-gray, slight greenish tint, silty ..

Sandstone, medium-light-gray, very fine to mediumgrained, probably very silty; many black rounded grains. Free drilling

Shale, olive-gray, silty to sandy. A 1-ft sandstone bed as above at 4,689

Sandstone, medium-gray, fine- to medium-grained, silty, clayey; many dark-gray to black rounded phosphatic-like grains; low porosity

Shale, olive-gray, silty, sandy

Dolomite, medium-light-gray to yellowish-gray, very fine grained, clayey, partly sandy; abundant black phosphaticlike grains in part

Sandstone, medium-gray, very fine to fine-grained, silty, clayey; abundant black rounded phosphaticlike grains 
Tertiary System-Continued

Pliocene Series-Continued

Etchegoin Formation-Continued

Tupman Shale Member-Continued

Buliminella silt zone-Continued phosphaticlike grains. May be caving

$4,770-4,772$

Shale, olive-gray, silty

Electrical-log interpretation; no samples from 4,805 to 4,895

Estimated sample lag-25 ft.

Shale, as above

$4,780-4,810$

Sandstone, as above

$4,810-4,814$

Shale, as above

Shale, medium-dark-gray, slight olive-gray tint, silty in part; abundant black rounded phosphaticlike grains in part

Shale, olive-gray, silty

Electrical-log interpretation; no samples from 4,925 to 4,965

Estimated sample lag-25 ft.

Shale, as above

$4,900-4,940$

Shale, medium-dark-gray to olive-gray, slight brownish tint in part, silty in part, finely sandy with sporbo in part

$4,940-4,960$

Shale, medium-dark-gray, slight green and brown tints in part, silty in part

Shale, olive-gray to greenish-gray, silty in part $5,015-5,040$

Shale, medium-gray to medium-dark gray and olive-gray, silty in part

$5,040-5,070$

Dolomite, pale-yellowish-brown, very fine grained, very clayey, hard, dense; subconchoidal fracture May be caving

Shale, greenish-gray, silty. May be caving

Shale, medium-dark-gray to olive-gray, silty

$5,070-5,072$

$5,072-5,080$

$5,080-5,135$

Shale, olive-gray, brownish tint, harder than above, probably siliceous

$5,135-5,180$

Shale, olive-gray, slight brownish tint, silty; thin beds and lenses of olive-gray sandy siltstone and silty very fine to fine-grained sandstone

$5,180-5,200$

$5,200-5,210$

Shale, olive-gray, brownish tint, probably siliceous ....

Siltstone, olive-gray, very finely to finely sandy, tight

$5,210-5,212$

Shale, olive-gray; thin beds and lenses of olive-gray siltstone

Sandstone, light-olive-gray to medium-gray, very fine to fine-grained, silty, tight, probably siliceous ..

Shale, medium-dark-gray

5,228-5,230 $5,230-5,233$

Olig sand zone:

Olig sand 5,233-5,300:

Sandstone, medium-light-gray to light-olive-gray, very fine to fine-grained, silty, probably siliceous ..

Shale, olive-gray

Sandstone, light-gray to yellowish-gray, fine- to 
Tertiary System-Continued

Pliocene Series-Continued

Etchegoin Formation-Continued

Tupman Shale Member-Continued

Olig sand zone-Continued

Olig sand-Continued

coarse-grained, some very coarse grains and granules, micaceous, dolomitic, some gray subrounded feldspar grains; little visible porosity

Estimated sample lag-20 ft.

Shale, olive-gray

Sandstone, as above; somewhat coarser, more free drilling; probably better porosity than above..

Sandstone, light-gray to yellowish-gray, fine- to coarse-grained, some very coarse grains and granules of quartz and feldspar, silty, white clay cement, not dolomitic, fair porosity

Shale, olive-gray, silty to finely sandy

Sandstone, light- to medium-gray, fine- to coarsegrained, very coarse grains and granules as above, dolomitic in part; little visible porosity

Shale, olive-gray, greenish tint in party, silty; sporbo in part

Shale, olive-gray to brownish-gray, siliceous, hard ....

Dolomite, pale-yellowish-brown to light-olive-gray, very fine grained, dense, clayey, probably siliceous to cherty in part

Siltstone, light-olive-gray, clayey

Shale, olive-gray, silty

Shale, olive-gray, brownish tint, probably siliceous ....

Siltstone, olive-gray, very finely to finely sandy, clayey, tight; interbedded with shale as above ........

Shale, olive-gray, brown tint in part, silty to finely sandy. Probably includes stringers of sandy clayey siltstone

$5,339-5,340$

$5,340-5,342$

$5,342-5,353$

$5,353-5,364$

$5,364-5,374$

Shale, medium-dark-gray, silty

Shale, olive-gray, brownish tint, probably siliceous ..

Shale, brownish-gray, silty

Sandstone, medium-gray to olive-gray, very fine to fine-grained, silty, clayey, tight

Siltstone, medium-gray to olive-gray, very finely sandy, clayey, tight

Shale, dark-gray, slight brownish tint, silty to finely sandy, siliceous in part

Dolomite, brownish-gray, dense, very clayey

Shale, as above

Sandstone, medium-dark-gray, very fine to fine-

Miocene Series: grained, silty, clayey, tight 
Tertiary System - Continued

Miocene Series-Continued

Reef Ridge Shale-Continued

sand grains

$5,464-5,468$

Shale, olive-gray, silty

Shale, medium-dark- to dark-gray, silty to finely sandy ..

Dolomite, pale- to moderate yellowish-brown, very fine grained, argillaceous

$5,468-5,505$

$5,505-5,520$

$5,520-5,521$

Shale, dark-gray, slight brownish tint, silty, probably siliceous

$5,521-5,530$

Sandstone, medium-gray, very fine to fine grained, silty, clayey, tight

Shale, olive-gray to medium-dark-gray, silty

$5,530-5,531$

$5,531-5,570$

Sandstone, medium-gray, very fine to fine-grained, silty, clayey, tight

Shale, olive-gray, silty

$5,570-5,572$

$5,572-5,590$

Shale, dark-gray, silty, very finely sandy in upper part.

May have sandstone stringers in upper part

Shale, olive-gray, silty

Shale, medium-gray to olive-gray, siliceous

Shale, medium-gray, silty to finely sandy; trace of coal.

Probably includes thin beds or laminae of very fine to fine-grained clayey sandstone

$5,590-5,635$

$5,635-5,650$

$5,650-5,660$

Shale, medium-dark- to dark-gray, slight brownish tint, silty to finely sandy; trace of coal (may be caving)

Sandstone, medium-dark-gray, very fine to fine-grained, very silty and clayey

Shale, as above

Dolomite, pale-yellowish-brown to light-olive-gray, very fine grained, very argillaceous, hard (may be caving) ..

Shale, olive-gray, silty

Shale, olive-gray, dark-gray streaks, may be siliceous

Shale, medium-gray, siliceous; dark-gray silty to finely sandy shale

Sandstone, olive-gray to medium-dark-gray, very fine to fine-grained, very silty, clayey; probably oil-stained in part; may be caving

Shale, medium-dark- to dark-gray, slight brownish tint, silty, very finely micaceous in lower 10 feet

$5,660-5,670$

$5,670-5,688$

$5,688-5,690$

$5,690-5,693$

5,693-5,694

$5,694-5,710$

$5,710-5,714$

$5,714-5,718$

$5,718-5,721$

$5,721-5,750$

$5,750-5,770$

Shale, medium-dark- to dark-gray, silty; trace of fish scales

Dolomite, moderate-yellowish-brown, very fine grained to dense, very argillaceous; may be caving

$5,770-5,780$

$5,780-5,781$

$5,781-5,805$

Silts, of sandy, clayey; may be caving

Shale, medium-dark-gray to olive-gray and greenishgray, silty to very finely sandy in part

Shale, dark-gray, silty

$5,820-5,830$

$5,830-5,838$

Shale, olive-gray, silty

$5,838-5,847$

Shale, dark-gray, silty to finely sandy

Sandstone, medium- to dark-gray, very fine to fine- 


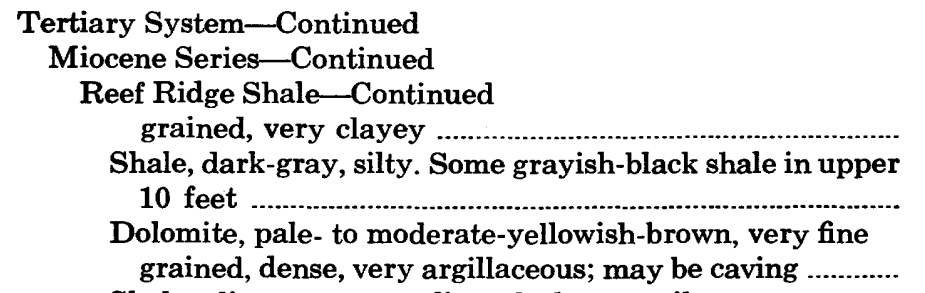

Shale, olive-gray to medium-dark-gray, silty

Dolomite, dusky-brown to dark-gray, very fine grained, very argillaceous, hard, tight; some round microfossils ..

Shale, dark-gray to grayish-black and olive-gray, silty ....

Shale, dark-gray; trace of coal

Shale, olive-gray, slight brownish tint, silty, siliceous in part. Probably interbedded with dark-gray shale as above

Shale, medium-gray, silty, streaked with dark-gray, probably slightly to moderately siliceous

Shale, olive-gray, silty

Dolomite, pale- to moderate-yellowish-brown, very fine grained to dense, very argillaceous, hard, siliceous

Shale, olive-gray to medium-dark-gray, slight brownish tint, silty

Siltstone, brownish-gray, olive-gray tint

Shale, dark-gray to grayish-black, silty; some very

finely sandy streaks in lower $25 \mathrm{ft}$.

Monterey Shale:

Elk Hills Shale Member:

N zone:

Shale, dark- to dusky-yellowish-brown, silty, dark-gray siliceous streaks

Estimated sample lag-25 ft.

Siltstone, medium-gray, abundant dark-gray streaks, siliceous, hard

Siltstone, diatomaceous (?), pale to moderateyellowish-brown, fairly soft; dark-gray streaks of organic material, very finely micaceous;

fish fragments

Shale, olive-gray, silty

Siltstone, as above

Shale, brownish-gray, dark-gray streaks, silty

Siltstone, diatomaceous (?), medium-light-gray to pale-yellowish-brown, dark-gray streaks, fairly soft, very finely micaceous

Siltstone, as above, but light-gray to yellowish-gray; probably interbedded with shale as above

Siltstone, light-gray to light-olive-gray, micaceous; sporbo in part; very finely sandy in part

Sandstone, light-gray, very fine to fine-grained, silty, clayey, micaceous; pelecypods, gastropods; fair porosity

Siltstone, as above

Shale, medium-gray to greenish-gray, silty, very

\author{
Depth
$($ ft $)$ \\ $5,847-5,850$ \\ $5,850-5,874$ \\ $5,874-5,875$ \\ $5,875-5,910$ \\ 5,910-5,911 \\ $5,911-5,925$ \\ $5,925-5,930$
}

5,930-5,952

5,952-5,965

$5,965-5,970$

5,970-5,972

$5,972-5,982$

5,982-5,985

5,985-6,035

6,035-6,045

$6,045-6,050$

6,050-6,055

$6,055-6,060$

$6,060-6,065$

6,065-6,070

$6,070-6,080$

$6,080-6,105$

$6,105-6,109$

$6,109-6,112$

$6,112-6,115$ 
Tertiary System-Continued

Miocene Series-Continued

Monterey Shale-Continued

Depth

(ft)

Elk Hills Shale Member-Coritinued

$\mathrm{N}$ zone-Continued

finely micaceous

$6,115-6,120$

Sandstone, medium-light-gray, very fine to fine-

grained, silty, clayey, micaceous; green clay (?)

grains; pelecypods

$6,120-6,124$

Shale, medium-light-gray, slight purplish tint,

dark-gray streaks; siliceous

$6,124-6,130$

Siltstone, diatomaceous (?), brownish-gray to yellowish-brown, mottled in part, dark-gray streaks, moderately siljceous

Shale, diatomaceous(?), brownish-gray, silty, siliceous

6,136-6,142

Siltstone, as ahnve

$6,142-6,150$

Siltstone, diatomaceous (?), very pale orange to paleyellowish-brown, dark-gray streaks

$6,150-6,154$

Shale, brownish-gray to dusky-brown, dark-gray streaks, silty, siliceous; fish fragments

6,154-6,164

6,164-6,175

Siltstone, as above

Siltstone, brownish-gray, gray streaks, siliceous

$6,175-6,182$

Shale, brownish-gray to dusky-brown and darkgray, silty

Siltstone, diatomaceous(?), pale-yellowish-brown, few dark-gray streaks

$6,182-6,198$

$6,198-6,208$

Shale, brownish-gray to dusky-brown and dark-gray, silty

$6,208-6,215$

Dolomite, brownish-gray, very fine grained to dense, hard, siliceous; much sil.t-size silica

Siltstone, diatomaceous (?), brownish-gray, mottled and streaked with dark.gray, moderately siliceous

Dolomite, as above. May be caving

Siltstone, as above

Siltstone, diatomaceous(?), brownish-gray, siliceous

Siltstone, diatomaceous (?), pale-yellowish-brown ....

Dolomite, pale-yellowish-brown, very fine grained, argillaceous

$6,225-6,235$

$6,235-6,237$

$6,237-6,245$

$6,245-6,250$

$6,250-6,258$

$6,258-6,262$

Siltstone, diatomaceous (?), brownish-gray to dark-gray, moderately siliceous

Siltstone, diatomaceous (?), pale-yellowish-brown ...

Shale, dark-gray to dark-brownish-gray, silty, moderate siliceous

6,288-6,300

Siltstone, diatomaceous (?), pale-yellowish-brown ....

$6,300-6,307$

Sandstone, medium-gray to greenish-gray, very fine to fine-grained, clayey, silty, micaceous; pelecypod fragments. May be caving

Siltstone, diatomaceous(?), brownish-gray, siliceous

Siltstone, diatomaceous (?), pale-yellowish-brown ....

Siltstone, diatomaceous (?), brownish-gray, siliceous 
Tertiary System-Continued

Miocene Series-Continued

Monterey Shale —Continued

Depth

(ft)

Elk Hills Shale Member-Continued

N zone-Continued

Shale, dusky-yellowish-brown, silty

$6,340-6,345$

Sandstone, medium-dark-gray, very fine to mediumgrained, clayey, very micaceous; may be oil-stained

Sandstone, medium-light-gray, very fine to mediumgrained, scattered coarse and very coarse grains, subangular, micaceous, dolomitic, silty; feldspar grains, scattered black grains; little visible porosity

Siltstone, diatomaceous(?), brownish-gray, siliceous

Shale, medium-dark-gray to brownish-gray, silty, moderately siliceous

$6,345-6,350$

Sandstone, medium-light-gray, very fine to finegrained, scattered medium grains, silty; fair porosity

Sandstone, greenish-gray, very fine to fine-grained, silty; pelecypod fragments

Siltstone, diatomaceous (?), brownish-gray to paleyellowish-brown, moderately siliceous

Siltstone, medium-dark-gray, slight brownish tint, very hard, siliceous, dolomitic; "grainy" fracture ..

Siltstone, diatomaceous(?), brownish-gray, moderately siliceous

Shale, brownish-gray to medium-dark-gray, silty, moderately siliceous in part; interbedded with brownish-gray moderately siliceous diatomaceous(?) siltstone

$6,403-6,447$

Siltstone, diatomaceous(?), pale-to-moderateyellowish-brown

Shale, brownish-gray to dusky-brown, silty

Siltstone, diatomaceous (?), brownish-gray, moderately siliceous

$6,350-6,352$

$6,352-6,359$

$6,359-6,366$

$6,366-6,370$

$6,370-6,374$

$6,374-6,390$

$6,390-6,392$

$6,392-6,403$

Shale, as above

Siltstone, as above

Shale, medium-dark-gray, silty to very finely sandy

Siltstone, diatomaceous (?), brownish-gray, moderately siliceous

Sandstone, medium- to medium-dark-gray, fine- to medium-grained, subangular, micaceous; siliceous cement, mostly hard and tight; oil-stained in part

Shale, medium-dark-gray, silty, siliceous

Siltstone, diatomaceous (?), pale-yellowish-brown to brownish-gray, moderately siliceous

$6,447-6,456$

$6,456-6,462$

$6,462-6,469$

$6,469-6,473$

$6,473-6,480$

$6,480-6,485$

$6,485-6,493$

$6,493-6,496$

$6,496-6,500$

$6,500-6,508$

Sandstone, medium-light-gray, very fine grained, silty, clayey; pelecypod fragments. May be caving

Siltstone, medium-dark-gray, dolomitic, hard, tight; few pelecypod fragments

Siltstone, diatomaceous (?), pale-yellowish-brown; gilsonite(?) vein 
Tertiary System-Continued

Miocene Series-Continued

Monterey Shale-Continued

Depth

Elk Hills Shale Member-Continued

$\mathrm{N}$ zone-Continued

Siltstone, diatomaceous (?), brownish-gray, siliceous

Chert, dusky-brown to brownish-black, dense

$6,523-6,530$

Siltstone, diatomaceous (?), dark-gray to duskybrown, very siliceous, finely sandy in lower part ....

Siltstone, diatomaceous (?), brownish-gray, darkgray streaks and films, siliceous

$6,544-6,554$

Shale, dark-gray, silty, siliceous

$6,544-6,560$

Siltstone, diatomaceous (?), pale-yellowish-brown to brownish-gray, abundant dark-gray streaks and films in part, very finely to finely sandy in upper half, very siliceous in part

$6,560-6,580$

Siltstone, diatomaceous (?), pale-yellowish-brown, moderately siliceous in part

$6,580-6,607$

Siltstone, diatomaceous (?), brownish-gray to darkgray, very siliceous

Siltstone, diatomaceous (?), pale-yellowish-brown, dark-gray streaks and films, siliceous and tight in part

$6,612-6,628$

Dolomite, pale-yellowish-brown to brownish-gray, very fine grained to dense, argillaceous in part, siliceous in part; scattered pinpoint porosity

Shale, dark-gray, silty

Sandstone, medium-gray, very fine to fine-grained, silty, clayey, micaceous; scattered dark-gray to black rounded grains

Shale, dark-gray, silty, sandy in part

Shale, dusky-brown, silty

Shale, olive-gray, dark-gray, and dusky-brown, silty

Sandstone, medium-dark-gray to brownish-gray, very fine to medium-grained, siliceous, hard; low porosity; may be oil-stained; (may have caved from 6,495)

Shale, dark-gray, silty

Siltstone, diatomaceous(?), pale-yellowish-brown to brownish-gray. May be caving. A 2-ft. shale bed $4 \mathrm{ft}$. below top

Shale, dark-gray to dusky-brown, silty to finely sandy in part

Sandstone, gray, very fine to fine-grained, clayey ......

Shale, medium-dark-gray, silty

$6,708-6,711$

$6,711-6,718$

Siltstone, diatomaceous (?), brownish-gray to duskybrown

Sandstone, medium-gray, fine- to medium-grained, subangular; abundant pyrite; hard, tight

Siltstone, diatomaceous (?), brownish-gray, moderately siliceous; probably interbedded with medium-dark-gray moderately siliceous shale 
Tertiary System-Continued

Miocene Series_Continued

Monterey Shale-Continued

Elk Hills Shale Member-Continued

A zone:

Siltstone, diatomaceous (?), pale-yellowish-brown to brownish-gray, moderately siliceous; interbedded with medium-dark-gray to brownish-gray moderately siliceous silty shale

Sandstone, light-gray, very fine to fine-grained, silty, slightly dolomitic; fairly porous

Siltstone, diatomaceous (?), pale-yellowish-brown, siliceous

Shale, medium-dark- to dark-gray

Dolomite, pale-yellowish-brown, dense, argillaceous to siliceous; some pyrite

Siltstone, diatomaceous (?), brownish-gray to duskybrown and dark-gray, siliceous; dusky-brown chert

Shale, dark-gray, siliceous, silty

$6,780-6,787$

$6,787-6,790$

Siltstone, diatomaceous (?), pale-yellowish-brown, siliceous

$6,790-6,796$

$6,796-6,802$

Shale, dark-gray, siliceous

Siltstone, as above; chert as above (may be caving) ..

Shale, medium-dark-gray to brownish-gray, silty ......

Dolomite, pale-yellowish-brown to brownish-gray, dense, argillaceous to very siliceous; trace of pinpoint porosity; quartz fracture fillings

$6,802-6,810$

$6,810-6,818$

Siltstone, diatomaceous (?), pale-yellowish-brown, siliceous, sandy in lower $5 \mathrm{ft}$. A 3-ft. gray shale bed $3 \mathrm{ft}$. below top

Shale, diatomaceous (?), dusky-brown and darkgray, laminated, siliceous, silty

Sandstone, light-gray, very fine grained, diatomaceous(?) in part, slightly micaceous; low porosity

$6,847-6,850$

Siltstone, diatomaceous (?), brownish-gray, duskybrown, and medium-dark-gray, siliceous. Probably includes stringers of light-gray very fine grained sandstone

$6,818-6,820$

Shale, dark-gray, silty, siliceous

Siltstone, as above

Shale, as above

Siltstone, diatomaceous(?), pale-yellowish-brown, siliceous

Shale, dark-gray, silty

Siltstone, as above

Shale, brownish-gray to dark-gray, siliceous, silty .....

Siltstone, as above; fracture fillings of calcite and pyrite

Shale, as above; may contain a few microfossils ........

Siltstone, diatomaceous (?), pale-yellowish-brown to brownish-gray, siliceous

Sandstone, brownish-gray, very fine grained, silty, 
Tertiary System-Continued

Miocene Series-Continued

Monterey Shale-Continued

Depth

Elk Hills Shale Member-Continued

A zone-Continued

siliceous, micaceous, tight

$6,940-6,941$

Shale, medium-dark-gray, silty

$6,941-6,945$

Dolomite, pale-yellowish-brown to brownish-gray, dense to very fine grained, argillaceous, hard, tight

$6,945-6,947$

Shale, brownish-gray to dark-gray, silty, siliceous ......

$6,947-6,955$

Siltstone, diatomaceous (?), pale-yellowish-brown to brownish-gray in lower part, siliceous, slightly dolomitic in part

6,955-6,982

Shale, brownish-gray, silty, siliceous

$6,982-6,988$

Dolomite, as above

$6,988-6,989$

Siltstone, diatomaceous (?), pale-yellowish-brown, siliceous, dolomitic in part

Shale, diatomaceous (?), medium-dlark to dark-gray and dusky-brown, silty, siliceous

$6,989-7,000$

$7,000-7,010$

Siltstone, as above

$7,010-7,020$

Shale, medium-dark-gray, silty

$7,020-7,026$

Siltstone, diatomaceous (?), pale-yellowish-brown, moderately siliceous

$7,026-7,030$

Shale, medium-gray, silty, fairly soft

$7,030-7,038$

Siltstone, as above

7,038-7,044

Shale, as above

$7,044-7,050$

Sandstone, medium-light-gray, very fine grained, silty; low porosity

$7,050-7,052$

Shale, as above

$7,052-7,060$

B zone:

Siltstone, diatomaceous (?), pale-yellowish-brown, siliceous; includes dusky-brown dense vitreous chert (may be caving)

Shale, brownish-gray to dusky-brown, silty, siliceous to very siliceous

$7,060-7,074$

$7,074-7,086$

Siltstone, as above. May include some mediumlight-gray very fine grained silty sandstone (probably caved from 7,050)

7,086-7,095

$7,095-7,110$

gray, silty, siliceous in part

Siltstone, diatomaceous (?), pale-yellowish-brown to brownish-gray, dark-gray films, siliceous, slightly dolomitic in part; microfossils

$7,110-7,123$

Sandstone, light-gray, very fine to fine-grained, subangular, silty, very micaceous, slightly dolomitic; fair porosity

7,123-7,132

Estimated sample lag- $40 \mathrm{ft}$.

Shale, medium-dark- to dark-gray, silty, moderately siliceous

Siltstone, as above; interbedded with shale as above ..

Shale, yellowish-gray to brownish-gray, siliceous, slightly dolomitic

Siltstone, diatomaceous(?), pale-yellowish-brown 
Tertiary System-Continued

Miocene Series-Continued

Monterey Shale - Continued

Depth

Elk Hills Shale Member-Continued

B zone-Continued

to brownish-gray, dark-gray films, siliceous.

Probably interbedded with dark-gray to brownish-

gray siliceous silty shale

$7,160-7,175$

Dolomite, pale-yellowish-brown to brownish-gray, dense to very fine grained, argillaceous to siliceous; may be caving

Shale, medium-dark-gray, silty

Siltstone, as above

Shale, as above. May include near the top a 1-ft bed of brownish-gray very fine grained argillaceous dolomite

Sandstone, medium-dark-gray, very fine to finegrained, silty, slightly dolomitic; low porosity

Sandstone, light- to medium-gray, very fine to finegrained, silty, micaceous; fair porosity; may have some oil-stain

7,204-7,209

Siltstone, diatomaceous(?), pale-yellowish-brown to brownish-gray, siliceous

$7,209-7,222$

Shale, medium-dark- to dark-gray and dusky-brown, silty, partly siliceous

Siltstone, diatomaceaus (?), medium-light-gray to brownish-gray, siliceous; includes white clay grains and stringers

Shale, as above

Siltstone, diatomaceous(?), pale-yellowish-brown to brownish-gray, siliceous; interbedded with shale as above

Sandstone, light-gray, very fine to fine-grained, silty, micaceous, slightly dolomitic. May be caving

Siltstone, diatomaceous (?), pale-yellowish-brown to brownish-gray, some dark-gray films and stringers, siliceous. A 2-ft brownish-gray silty shale bed near top

Shale, dark-gray, silty, moderately siliceous

Siltstone, as above

Shale, medium-dark- to dark-gray and olive-gray, silty to sandy, micaceous, siliceous

Sandstone, medium-dark-gray, very fine to finegrained, silty to very clayey; some light-gray very fine grained silty micaceous sandstone

Shale, medium-dark-gray, slight brownish tint, silty, siliceous

Siltstone, medium-dark- to dark-gray, very finely to finely sandy, siliceous, hard, tight

Siltstone, diatomaceous(?), brownish-gray, siliceous

Dolomite, brownish-gray, very fine grained, very 
Tertiary System - Continued

Miocene Series-Continued

Monterey Shale - Continued

Elk Hills Shale Member-Continued

B zone-Continued

argillaceous, hard, tight. May be caving

$7,349-7,351$

Shale, as above

Siltstone, medium-light- to medium-gray, very finely sandy, siliceous, hard, tight

$7,351-7,356$

Shale, brownish-gray, silty, siliceous

$7,356-7,360$

$7,360-7,367$

Siltstone, as above

Shale, medium-dark- to dark-gray, silty, moderately siliceous

$7,367-7,373$

$7,373-7,386$

Sandstone, light-gray, very fine to fine-grained, silty; some mica and dark grains; fair porosity. Some greenish-gray very fine to fine-grained clayey sandstone

Siltstone, greenish-gray, very finely to finely sandy, micaceous

Shale, as above $7,394-7,400$

Siltstone, diatomaceous (?), pale-yellowish-brown, siliceous; few very fine and fine sand grains

$7,400-7,407$

Sandstone, greenish-gray to medium-gray, very fine to fine-grained, very clayey; common black phosphaticlike grains (probably sporbo)

$7,407-7,409$

Shale, medium-dark- to dark-gray, silty $7,409-7,417$

Shale, diatomaceous (?), brownish-gray, silty. Probably includes stringers of pale-yellowishbrown diatomaceous (?) siltstone

$7,417-7,429$

Siltstone, brownish-gray to medium-dark-gray, very finely to finely sandy, siliceous

$7,429-7,432$

Sandstone, light-gray, very fine grained, silty; scattered dark-gray grains; fairly good porosity ....

Sandstone, medium-gray, very fine grained, silty, siliceous, tight

7,432-7,436

$7,436-7,439$

C zone:

Shale, medium-dark- to dark-gray and brownishgray, silty

Dolomite, brownish-gray to dusky-brown, light-gray streaks in part, very fine grained, argillaceous, hard, tight; crystalline fillings in fractures or vugs

Shale, as above

Siltstone, diatomaceous(?), pale-yellowish-brown to brownish- gray, siliceous, slightly dolomitic in part

Shale, dark-gray, silty, siliceous

Siltstone, diatomaceous (?), brownish-gray, siliceous

Shale, dark-brownish-gray, silty, siliceous

Shale, dark-gray to grayish-black, silty, very micaceous, siliceous

Shale, dark-brownish-gray to dark-gray, silty, siliceous in part

Sandstone, medium-light-gray, very fine grained, silty; low porosity 
Tertiary System-Continued

Miocene Series-Continued

Monterey Shale-Continued

Elk Hills Shale Member-Continued

C zone-Continued

Shale, dark-brownish-gray to dark-gray, silty, partly siliceous in lower $10 \mathrm{ft}$.

Sandstone, as above. May be caving

Siltstone, diatomaceous (?), pale-yellowish-brown to brownish-gray, siliceous; some very fine and fine sand grains

$7,542-7,547$

Shale, dusky-brown to dark-gray in lower part, silty, siliceous

$7,547-7,560$

Sandstone, medium-gray, very fine grained, silty, siliceous, slightly dolomitic, tight; may be caving ....

Siltstone, diatomaceous (?), brownish-gray, siliceous

Shale, as above

Sandstone, as above

Shale, medium-dark- to dark-gray, silty

Sandstone, as above; may be caving

Siltstone, diatomaceous(?), brownish-gray, siliceous

Shale, dark-brownish-gray to dark-gray in lower part, silty, moderately siliceous in part

$7,560-7,562$

$7,562-7,567$

$7,567-7,570$

$7,570-7,572$

$7,572-7,588$

$7,588-7,590$

$7,590-7,594$

7,594-7,613

Shale, dark-brownish-gray to medium-dark-gray in lower part, silty, siliceous in part. Probably includes a few thin brownish-gray siliceous diatomaceous (?) siltstone beds

$7,613-7,662$

Dolomite, dusky-brown to pale-yellowish-brown, dense to very fine grained, argillaceous, hard; white crystalline dolomite fillings in fractures and vugs

$7,662-7,665$

Shale, dark-brownish-gray to dark-gray, silty, moderately siliceous in part

Dolomite, dusky-brown to brownish-black, very fine grained, very argillaceous, hard, tight

$7,665-7,676$

$7,676-7,678$

7,678-7,683

Shale, dark-gray, silty, micaceous

Siltstone, diatomaceous (?), brownish-gray, moderately siliceous

Shale, brownish-gray to pale-yellowish-brown, silty, moderately siliceous

$7,683-7,686$

$7,686-7,706$

Siltstone, diatomaceous(?), pale-yellowish-brown to brownish-gray, moderately siliceous

Shale, as above; interbedded with siltstone as above ..

Shale, dark-gray to grayish-black, silty; few lightgray clay fragments; questionable microfossils ......

Shale, medium-dark-gray, slight brownish tint, silty; questionable microfossils

7,706-7,710

7,710-7,723

$7,723-7,740$

$7,740-7,757$

7,757-7,770

Shale, as above, moderately siliceous ................... argillaceous, hard, tight. May be caving

$7,770-7,772$

7,772-7,783

7,783-7,788

Siltstone, diatomaceous (?), pale-yellowish-brown to 
Tertiary System-Continued

Miocene Series-Continued

Monterey Shale-Continued

Elk Hills Shale Member-Continued

C zone-Continued

brownish-gray, siliceous, slightly dolomitic;

microfossils

7,788-7,792

Shale, as above

$7,792-7,798$

Shale, brownish-gray, silty, siliceous

7,798-7,806

D zone:

Siltstone, diatomaceous (?), pale-yellowish-brown, moderately siliceous

$7,806-7,810$

Shale, diatomaceous (?), pale-yellowish-brown to medium-dark-gray, siliceous

$7,810-7,814$

Siltstone, diatomaceous (?), pale-yellowish-brown, siliceous, slightly dolomitic in part

Shale, medium-dark-gray, silty, siliceous .

Siltstone, as above

Shale, as above

Siltstone, dark-gray, very finely sandy, siliceous, micaceous, tight

Shale, as above

Siltstone, diatomaceous (?), pale-yellowish-brown, siliceous; interbedded with dusky-brown dense chert and very siliceous shale

$7,814-7,818$

7,818-7,821

$7,821-7,825$

$7,825-7,827$

$7,827-7,830$

$\mathbf{7 , 8 3 0 - 7 , 8 3 2}$

$7,832-7,845$

Siltstone, diatomaceous (?), pale-yellowish-brown, siliceous, slightly dolomitic. Sidewall cored at 7,850 (no recovery)

$7,845-7,853$

Shale, dark-gray to brownish-gray, very siliceous; some dusky-brown to brownish-black dense chert .-

Siltstone, diatomaceous (?), pale-yellowish-brown, finely banded with dark-gray, siliceous. Sidewall cored at 7,865

Siltstone, diatomaceous (?), dark-brownish-gray, siliceous, slightly dolomitic; scattered very fine and fine sand grains

$7,853-7,860$

$7,860-7,870$

$7,870-7,875$

7,875-7,878

Shale, dark-gray, silty, siliceous

Dolomite, pale-yellowish-brown to brownish-gray, very fine grained, argillaceous, hard; some pinpoint porosity

Siltstone, diatomaceous (?), brownish-gray to darkbrownish-gray, siliceous

Shale, diatomaceous (?), dark-brownish-gray, silty, siliceous

Shale, pale-yellowish-brown, brownish-gray and dark-gray laminae, silty, siliceous

Dolomite, pale-yellowish-brown, very fine grained, argillaceous, hard; few small vugs and some pinpoint porosity. May be caving

Siltstone, diatomaceous (?), pale-yellowish-brown, siliceous, slightly dolomitic in part; white calcite in fractures. Sidewall cored at 7,924 and 7,929 (no recovery at 7,929 )

$7,878-7,880$

$7,880-7,894$

7,894-7,900

$7,900-7,918$

7,918-7,920

7,920-7,933 
Tertiary System - Continued

Miocene Series-Continued

Monterey Shale-Continued

Elk Hills Shale Member-Continued

D zone-Continued

Shale, brownish-gray to dark-gray, silty, siliceous; questionable microfossils; some brownish-black to dark-gray dense chert

$7,933-7,945$

Siltstone, as above

Shale, as above; some dusky-brown to brownish-black dense chert and banded chert

Siltstone, diatomaceous (?), pale-yellowish-brown to brownish-gray, siliceous, slightly dolomitic, may be fractured; microfossils; chert as above

hale, dark-gray; questionable gilsonite in fractures

Dolomite, pale-yellowish-brown, very fine grained; abundant very fine silica

Siltstone, diatomaceous (?), very pale-orange to paleyellowish-brown, siliceous, slightly dolomitic in upper part; brownish-gray to dusky-brown dense and banded chert; thin beds of dark-gray silty siliceous shale near middle. Sidewall cored at $8,004,8,015$, and 8,028 (no recovery at 8,028)

Shale, pale-yellowish-brown, with brownish-gray, dusky-brown, and dark-gray bands, siliceous, silty; questionable microfossils in part; dark-brownishgray to dark-gray banded chert

Shale, pale-yellowish-brown to medium-light-gray, silty, siliceous

Siltstone, as above

Siltstone, brownish-gray to dark-gray, micaceous, siliceous, tight; scattered very fine and fine sand grains

Shale, olive-gray, brownish-gray, and dark-gray, silty, siliceous, micaceous; scattered very fine and fine sand grains

Siltstone, diatomaceous (?), brownish-gray to paleyellowish-brown, siliceous

Shale, brownish-gray to dark-gray, silty, siliceous; interbedded with siltstone as above

Siltstone, diatomaceous (?), pale-yellowish-brown, siliceous

Shale, medium-dark-gray, slight brownish tint, very siliceous, silty; dark-brownish-gray to dark-gray dense chert and banded rough chert

Shale, dark-brownish-gray, fine dark-gray bands, siliceous; chert as above

Siltstone, diatomaceous (?), pale-yellowish-brown, dark-gray bands, siliceous; brownish-gray dense banded chert

Siltstone, dark-gray, very finely to finely sandy, siliceous, tight 
Tertiary System-Continued

Miocene Series-Continued

Monterey Shale-Continued

Elk Hills Shale Member-Continued

D zone-Continued

Sandstone, medium-dark-gray, very fine to mediumgrained, very siliceous, hard, tight; dark-gray sandy chert

Shale, medium-dark- to dark-gray, silty, siliceous; few white round questionable microfossils; darkbrownish-gray dense chert and banded chert

Siltstone, diatomaceous (?), pale-yellowish-brown to brownish-gray, siliceous; interbedded and interlaminated with dark-brownish-gray siliceous cherty shale as above. Siltstone and shale probably fractured. Sidewall cored at 8,214

Sandstone, light-gray, very fine to medium-grained, scattered coarse grains, very silty, some feldspar grains, slightly dolomitic and glauconitic, soft. Sidewall cored at 8,216

Siltstone, as above; interbedded with shale as above. Sidewall cored at 8,219 (no recovery)

Shale, diatomaceous (?), brownish-gray to darkbrownish-gray, silty, siliceous; few white siliceous questionable microfossils

Shale, medium-dark- to dark-gray, silty, siliceous, very finely to finely sandy in upper part; few microfossils

Shale, brownish-black, silty, siliceous

Siltstone, brownish-gray, siliceous; dark-brownishgray dense chert

Shale, dark-brownish-gray, silty, siliceous; darkbrownish-gray dense chert

Dolomite, pale-yellowish-brown to brownish-gray, very fine grained, hard, tight; abundant very finely divided silica; white crystalline calcite in fractures

Shale, as above

Siltstone, diatomaceous (?), pale-yellowish-brown to brownish-gray, finely banded, siliceous; probably interbedded with shale as above

Shale, as above

Sandstone, medium-dark-gray, very fine to finegrained, scattered medium grains, very silty, siliceous, micaceous, tight

Shale, dark-gray to grayish-black, silty, siliceous ......

Sandstone, medium-light- to medium-gray, very fine to fine-grained, silty, micaceous, tight; may be caving

Shale, brownish-gray to dark-brownish-gray, silty, siliceous, dolomitic in part

Dolomite, pale-yellowish-brown, dense, argillaceous, hard; may be caving 
Tertiary System-Continued

Miocene Series-Continued

Monterey Shale-Continued

Elk Hills Shale Member-Continued

D zone-Continued

Shale, medium-dark-gray to dark-brownish-gray, silty, siliceous in part; questionable Foraminifera in part

Sandstone, medium-dark-gray, very fine grained, silty, siliceous, some pyrite, tight

Shale, dark-gray, silty, micaceous, siliceous

Shale, dark-brownish-gray to medium-dark-gray, silty, siliceous in part, finely banded; darkbrownish-gray to brownish-black dense chert

Shale, as above; interbedded with pale-yellowishbrown to dark-brownish-gray siliceous diatomaceous (?) siltstone; chert as above

Siltstone, medium-gray, very finely to finely sandy, micaceous

Shale, dark-gray to grayish-black, silty, very micaceous

$8,444-8,450$

Siltstone, light-gray, tight

$8,450-8,454$

Sandstone, medium-light-gray, very fine to mediumgrained, subangular, silty, micaceous; low porosity

Siltstone, diatomaceous (?), brownish-gray, very DD zone: finely to finely sandy, siliceous

Shale, dark-gray to grayish-black, silty to very finely sandy

Siltstone, diatomaceous (?), brownish-gray, finely banded, siliceous; calcite-filled fractures; darkbrownish-gray to brownish-black dense chert (may be caving)

$8,480-8,484$

$8,484-8,489$

$8,489-8,492$

Siltstone, as above; chert as above

Shale, dark-brownish-gray to dark-gray, silty, siliceous; chert as above

$8,492-8,500$

Siltstone, medium- to dark-gray, very finely to finely sandy in part, siliceous, abundant mica in part

$8,500-8,509$

Shale, medium-dark- to dark-gray, silty, siliceous, partly micaceous

$8,509-8,517$

Shale, dark-brownish-gray to dark-gray, silty; probably interbedded with medium-dark-gray micaceous siltstone

$8,517-8,535$

Shale, diatomaceous (?), dusky-yellowish-brown to dark-brownish-gray, finely banded, siliceous

Siltstone, medium-dark-gray, very finely sandy, siliceous

Shale, dark-gray, silty

Dolomite, dusky-yellowish-brown to brownish-black, very fine grained, very argillaceous, hard, tight; trace of pinpoint porosity and small vugs 
Tertiary System-Continued

Miocene Series-Continued

Monterey Shale-Continued

Depth

Elk Hills Shale Member-Continued

DD zone-Continued

Siltstone, medium-dark-gray, micaceous

$8,587-8,590$

Sandstone, medium-gray, very fine grained, silty, micaceous, siliceous, tight; calcite in fractures

$8,590-8,594$

Shale, medium-dark- to dark-gray, silty, slightly to moderately siliceous; interbedded with mediumdark-gray micaceous siltstone

$8,594-8,610$

Sandstone, medium-gray to light-olive-gray, very fine to fine-grained, very siliceous

$8,610-8,612$

Shale, as above

$8,612-8,618$

Sandstone, light-gray, very fine to medium-grained, scattered coarse grains, subangular, silty, slightly dolomitic and micaceous; scattered dark-gray shale grains, some yellowish-brown clay grains, fair porosity

Sandstone, as above, clayey; scattered carbonaceous films; less porous than sandstone above

$8,622-8,627$

Siltstone, medium-dark-gray, micaceous; interbedded with dark-gray silty shale. Some shale shows slickensides

$8,627-8,650$

Sandstone, light-gray, very fine to fine-grained, silty, slightly micaceous; scattered carbonaceous frag. ments; low porosity

Limestone, pale-yellowish-brown, very fine grained, moderately to very argillaceous

Shale, medium-dark-gray, silty $8,660-8,663$

Sandstone, medium- to dark-gray, very fine to medium-grained, very silty; scattered mica and carbonaceous fragments; tight

$8,663-8,666$

Shale, dark-gray to dark-brownish-gray, silty, siliceous

Sandstone, medium-light-gray, very fine grained, silty, micaceous

Shale, dark-brownish-gray, silty, siliceous

Shale, medium-dark-gray, very silty and micaceous ..

Shale, light-gray, silty to finely sandy, slightly micaceous, may be bentonitic, flaky in part; scattered dark-gray fragments. Probably includes thin stringers of light-gray clayey very fine to fine-grained sandstone

$8,700-8,710$

Shale, medium-gray, silty, slightly micaceous, may be bentonitic, splintery

E zone:

Siltstone, medium-light- to medium-dark-gray, very finely to finely sandy, micaceous

Sandstone, medium-light- to medium-dark-gray, mottled, very fine to medium-grained, very silty, micaceous; scattered carbonaceous material; very "dirty" 


\section{Tertiary System-Continued \\ Miocene Series-Continued \\ Monterey Shale-Continued \\ Elk Hills Shale Member-Continued \\ E zone-Continued}

Sandstone, as above, except very fine to coarsegrained; some yellowish-brown clay grains, some questionable oil-stain; low porosity

Siltstone, as above

$8,730-8,735$

$8,735-8,740$

Sandstone, as above

$8,740-8,741$

Shale, dark-gray, micaceous

Sandstone, as above, many very coarse grains, some feldspar grains. A 2-foot gray shale bed in middle ..

Shale, medium-dark- to dark-gray, slight brownish tint. Probably includes a 1-foot bed of mediumgray very fine to medium-grained very silty tight sandstone at 8,769 (may be caving)

Siltstone, medium-dark-gray, micaceous, sandy in part; scattered carbonaceous material. Probably interbedded with shale as above

Shale, dark-gray to grayish-black

Siltstone, medium-light-gray, sandy, micaceous, tight, hard; questionable coal films and stringers in small part

Shale, dark-gray

Shale, dark-brownish-gray to dark-gray, finely banded, siliceous; calcite in fractures. Probably includes a 2-foot bed of gray hard tight siltstone $6 \mathrm{ft}$ below top

Shale, dark-gray, micaceous, silty

Sandstone, medium-light- to medium-gray, very fine grained, silty, micaceous; many yellowish-brown clay grains; low porosity

Shale, as above; interbedded with medium-darkgray micaceous hard siltstone

Sandstone, medium-light-gray, very fine to mediumgrained, scattered coarse grains, some feldspar and clay grains, silty, slightly dolomitic; scattered carbonaceous material; fairly good porosity

Shale, gray

Sandstone, as above, somewhat coarser; some wellsorted fine-grained dolomitic sandstone with fairly good porosity

Shale, dark-greenish-gray; may be caving

Sandstone, light- to medium-gray, very fine to coarse-grained, scattered very coarse grains, some feldspar and clay grains as above, silty, slightly micaceous and dolomitic, clayey in part; scattered coaly fragments; fair to poor porosity. A 1-ft gray shale bed $6 \mathrm{ft}$ below top

Sandstone, yellowish-gray, very fine to coarsegrained, very limy; probably fair porosity 
Tertiary System-Continued

Miocene Series-Continued

Monterey Shale - Continued

Depth

Elk Hills Shale Member-Continued

E zone-Continued

Sandstone, light-gray, fine- to coarse-grained, silty; probably low porosity

Sandstone, medium-light-gray to yellowish-gray, very fine to fine-grained, scattered medium and coarse grains in part, silty, very siliceous; very fine pyrite in part; tight

$8,915-8,929$

Shale, medium-dark- to dark-gray, silty, micaceous ..

Shale, as above; interbedded with some mediumlight-gray siliceous siltstone

Siltstone, medium-dark- to dark-gray, micaceous; probably interbedded with shale as above and some siliceous shale

$8,970-8,987$

Siltstone, medium-dark- to dark-gray, micaceous, siliceous

Shale, medium-dark- to dark-gray, silty in part, micaceous in lower half

Siltstone, medium- to dark-gray, micaceous, hard; abundant very fine pyrite in small part; tight; probably interbedded with shale as above

9,054-9,060

$9,060-9,067$

9,067-9,070

Siltstone, as above

$9,070-9,084$

Sandstone, medium-light-gray, very fine to finegrained, silty, micaceous; low porosity

Shale, dark-gray, siliceous; dark-gray dense chert with trace of pyrite

Shale, dark-gray, micaceous, silty

Sandstone, light-gray, very fine to medium-grained, some coarse grains, silty, dolomitic to limy, some feldspar grains, slightly micaceous; fair porosity ....

Siltstone, medium-dark-gray, very finely to medium sandy

Sandstone, light-gray, very fine to fine-grained, scattered medium grains, silty, dolomitic, slightly micaceous; some carbonaceous material

Shale, dark-gray to grayish-black, silty, micaceous ....

Sandstone, as above

Shale, medium-dark- to dark-gray, silty in part, micaceous; interbedded with medium-dark-gray micaceous siltstone

Sandstone, medium-light-gray, very fine to finegrained, scattered medium grains, silty; low porosity

Shale, as above

Sandstone, medium-light- to medium-dark-gray, very fine to fine-grained, some medium grains, silty, clayey, dolomitic in part, micaceous; some carbonaceous fragments; "dirty;" low porosity. 


\section{Tertiary System-Continued \\ Miocene Series-Continued \\ Monterey Shale-Continued \\ Elk Hills Shale Member-Continued \\ E zone-Continued}

Interbedded with much shale as above

9,182-9,198

Limestone, pale- to dark-yellowish-brown, dense, argillaceous, dolomitic, very finely to medium

sandy in part, hard

Depth

(ft)

Shale, medium-dark- to dark-gray, silty

Sandstone, medium-gray, very fine to mediumgrained, silty, siliceous, hard, tight

Shale, medium-dark- to dark-gray, micaceous, silty in upper half; may include trace of coal at about 9,220

Shale, dark-gray to dark-brownish-gray, siliceous.

May be caving

Siltstone, medium-gray, very finely sandy, siliceous, slightly micaceous, hard, tight

Shale, dark-gray, very siliceous; some dark-gray dense chert with slight brownish tint in part

Limestone, pale-yellowish-brown, very fine grained, very dolomitic, argillaceous

Shale, dark-gray, silty, slickensides

Siltstone, medium-dark-gray, clayey to very finely sandy

Shale, dark-brownish-gray to dark-gray, finely banded, very siliceous; some dark-brownish-gray to dark-gray dense chert and banded chert

Siltstone, medium- to medium-dark-gray, very finely to finely sandy, micaceous

Shale, medium-dark- to dark-gray

9,289-9,294 9,294-9,305

Shale, medium-dark- to dark-gray and darkbrownish-gray, siliceous; some dark-gray to brownish-black dense chert and rough chert

Shale, similar to above; probably less siliceous and cherty

Shale, brownish-gray, fairly soft

Shale, dark-brownish-gray to dark-gray, siliceous ....

Shale, as above; much dark-gray and dark-brownishgray to brownish-black dense chert

Shale, light-gray to pale-yellowish-brown, flaky, may be bentonitic; scattered mica and fine to medium sand grains

Shale, dark-gray, siliceous; much chert as above, calcite in fractures

Shale, dark-brownish-gray, very siliceous; some chert as above

Shale, medium-dark-gray, siliceous, silty, micaceous; some chert as above

$9,305-9,340$

$9,340-9,365$

$9,365-9,370$

$9,370-9,380$

$9,380-9,400$

$9,400-9,403$

9,403-9,420

$9,420-9,435$

$9,435-9,445$

Chert, dark-gray to dark-brownish-gray, dense to very finely grained; calcite in fractures; some brownish-gray silty siliceous finely banded shale .. 
Tertiary System-Continued

Miocene Series-Continued

Monterey Shale-Continued

Depth

Elk Hills Shale Member-Continued

E zone-Continued

Shale, medium-dark-gray, siliceous, silty; some chert as above

Shale, dark-gray to dark-brownish-gray, very siliceous; fine bands and lenses of yellowish-gray limy shale; some chert as above

Sandstone, light- to medium-gray, very fine to medium-grained, silty, slightly dolomitic; abundant pyrite in part; tight; may be caving ........

Siltstone, diatomaceous (?), pale-yellowish-brown, very finely to medium sandy, finely banded

Shale, dark-gray to dark-brownish-gray, very siliceous, finely banded; dark-gray to brownishblack dense to banded chert with white calcite in fractures

Sandstone, medium-light-gray, very fine to finegrained, silty, siliceous, micaceous, slightly dolomitic; tight

$9,478-9,482$

$9,482-9,487$

Sandstone, medium-light-gray, very fine to mediumgrained, scattered coarse grains, few feldspar grains, silty, micaceous, slightly dolomitic; low porosity

Sandstone, as above; yellowish-gray in part; a few very coarse grains; trace of questionable glauconite

McDonald Shale Member of local usage:

Shale, dark-gray to brownish-black, very siliceous; some dark-gray to brownish-black dense chert

Shale, pale-olive, light-olive-gray, and light-gray, flaky; may be bentonitic; scattered very fine to fine sand grains and dark-gray grains. May be caving

Shale, dark-gray, siliceous. Probably interbedded with medium-dark- to dark-gray micaceous shale

Shale, medium-dark- to dark-gray and dark-brownishgray

Shale, as above; probably siliceous

Shale, medium-dark- to dark-gray, fairly fissile, not siliceous. Probably interbedded with light- to medium-gray very fine to fine-grained silty micaceous sandstone in middle part

Shale, as above; slightly dolomitic in part

Sandstone, medium-gray, very fine to fine-grained, silty; may be caving

Shale, medium-dark- to dark-gray; some medium-gray fairly soft limy shale with slight brownish tint

Sandstone, medium-light-gray, very fine to finegrained, silty; may be caving

Shale, medium-dark- to dark-gray, siliceous in part. A 2-ft bed of medium-dark-gray siltstone $7 \mathrm{ft}$ above base 
Tertiary System-Continued

Miocene Series-Continued

Monterey Shale - Continued

McDonald Shale Member-Continued

Sandstone, medium-light-gray, very fine to fine-

grained, few medium grains, silty, micaceous, slightly dolomitic; few carbonaceous fragments; low porosity

Shale, medium-dark- to dark-gray, siliceous in part ......

Shale, light-gray, flaky, may be bentonitic; may be caving

Shale, medium-dark- to dark-gray

Shale, medium-gray, limy, fairly soft

Siltstone, medium-light- to medium-dark-gray, very siliceous in part, some carbonaceous material, mica, and pyrite

Shale, as above

$\mathbf{9 , 7 5 7 - 9 , 7 6 1}$

$\mathbf{9 , 7 6 1 - 9 , 7 7 0}$

$9,770-9,773$

$\mathbf{9 , 7 7 3 - 9 , 7 8 0}$

$9,780-9,788$

9,788-9,791

$\mathbf{9 , 7 9 1 - 9 , 7 9 7}$

Devilwater Shale(?) Member:

Shale, brownish-gray, fine dark-brownish-gray and dark-gray bands, very siliceous; dusky-brown dense chert

Electrical-log interpretation; no samples from 9,820 to 9,846

Estimated sample lag-10 ft.

Shale, as above; chert as above

Sandstone, probably silty and siliceous as below

Siltstone, probably sandy and siliceous

Sandstone, medium-light- to medium-gray, very fine to fine-grained, scattered medium grains, silty, siliceous, slightly dolomitic and micaceous in part; some carbonaceous material; tight. (Described from first sample below 9,846 .)

Siltstone, medium-gray, sandy, siliceous, tight

Shale, medium-dark- to dark-gray

Sandstone, as above

Shale, medium-dark- to dark-gray, moderately siliceous and brittle

Sandstone, medium-gray, very fine to medium-grained, silty, siliceous, slightly dolomitic, some pyrite and mica in parts; tight

Shale, dark-gray, siliceous; dark-gray chert

Sandstone, medium-light-gray, very fine to mediumgrained, silty, slightly dolomitic; fair porosity

9,898-9,900

Shale, medium-dark- to dark-gray, slight brownish tint in part

$9,900-9,916$

Shale, medium-gray, slightly limy; fairly common

Foraminifera

$9,916-9,920$

$9,920-9,937$

Shale, medium-dark- to dark-gray

Shale, medium-gray, slightly limy; few Foraminifera ....

$9,937-9,940$

Shale, medium-dark- to dark-gray

$9,940-9,955$

Shale, medium-gray, slightly limy; microfossils

9,955-9,958

Gould Shale Member:

Shale, medium-dark- to dark-gray

Shale, medium-gray, slightly limy; microfossils 
Tertiary System-Continued

Miocene Series-Continued

Monterey Shale-Continued

Gould Shale Member-Continued

Limestone, medium-dark-gray to dark-brownish-gray, very fine grained, very argillaceous; few microfossils

Shale, medium-dark- to dark-gray, slightly limy; few microfossils

Shale, dark-gray, limy, fairly hard; abundant microfossils. Resembles "dirty" limestone

Shale, brownish-gray to dark-gray, limy, very siliceous; abundant microfossils

Limestone, brownish-gray to dusky-yellowish-brown, dense, hard, very argillaceous; few microfossils (probably Foraminifera)

Shale, as above; crystalline calcite in fractures

Limestone, brownish-gray, dense, dolomitic, argillaceous; few microfossils; some pinpoint porosity

Shale, dark-gray, siliceous in part

Sandstone, medium-light-gray, very fine to finegrained, scattered medium grains, silty, dolomitic, slightly micaceous; low porosity

Shale, medium-dark- to dark-gray, slight brownish tint in part, siliceous in lower part

Sandstone, medium-light- to medium-dark-gray, very fine to fine-grained, silty, siliceous, slightly micaceous and dolomitic; tight

Shale, dark-gray, siliceous in part

Shale, medium-dark-gray to brownish-gray, very siliceous; sparse to abundant microfossils (mostly Foraminifera)

Shale, brownish-gray, less siliceous and softer than shale above; some microfossils (Foraminifera)

Shale, medium-dark-gray to dark-brownish-gray, very siliceous; abundant microfossils as above

Shale, medium-gray, slight greenish tint in part, slightly limy

Temblor Formation:

Carneros Sandstone Member:

First Carneros sand 10,143-10,151:

Sandstone, light-gray, very fine to fine-grained, scattered medium grains, very silty, clayey, slightly limy and micaceous, slightly glauconitic; probably low porosity; includes some hard tight sandstone. Sidewall cored at 10,149

Shale, as above

Shale, medium-dark- to dark-gray, silty, mostly siliceous

Second Carneros sand 10,196-10,243:

Sandstone, light- to medium-gray, fine- to mediumgrained, some coarse grains, subangular, silty, slightly limy to limy, very siliceous in uppermost 
Tertiary System-Continued

Miocene Series-Continued

Temblor Formation-Continued

Carneros Sandstone Member-Continued

Second Carneros sand-Continued

part, many dark-gray grains, some pyrite and glauconite; low porosity

Sandstone, as above; probably fair porosity. Sidewall cored at 10,206 and 10,210 (no recovery at 10,210)

$10,196-10,204$

Sandstone, medium-light-gray, very fine to finegrained, scattered medium grains, subangular, limy, silty, many dark-gray grains, slightly glauconitic. Sidewall cored at 10,216

$10,204-10,210$

Shale, dark-brownish-gray, silty, slightly dolomitic and glauconitic; some very finely to coarsely sandy stringers. Sidewall cored at 10,222

Sandstone, as above; fine- to coarse-grained. Sidewall cored at 10,228 (no recovery)

Dolomite, dark-brownish-gray to dark-gray, very fine grained, dense, argillaceous, siliceous, limy, hard. Sidewall cored at 10,232

Sandstone, as above

Shale, dark-gray, silty

Sandstone, as above; siliceous; tight

$10,210-10,221$

Shale, dark-gray, brownish tint in part, very siliceous

$10,231-10,232$

$10,232-10,235$

$10,235-10,240$

$10,240-10,243$

$10,243-10,260$

Shale, medium-dark-gray to dark-brownish-gray, slightly limy to limy, siliceous in upper part, silty in lower half; some mịcrofossils

$10,260-10,285$

Shale, medium-gray, silty, may be bentonitic, slightly micaceous, few dark specks; very fine "grainy" fracture

$10,285-10,290$

Shale, medium-dark- to dark-gray, slightly limy; few microfossils

$10,290-10,300$

Shale, as above; silty in part

$10,300-10,320$

Shale, medium-dark- to dark-gray, slightly limy in part; fairly common Foraminifera, probably other microfossils. Some shale altered to grayish-black color in bag

$10,320-10,340$

Shale, very light- to light-gray, may be bentonitic; dark specks and waxy luster in part

$10,340-10,344$

Shale, medium-dark- to dark-gray, very silty

Shale, medium-dark- to dark-gray, silty in part, moderately siliceous

$10,344-10,350$

$10,350-10,358$

Dolomite, dark-brownish-gray, very fine grained, argillaceous, hard

$10,358-10,362$

Sandstone, medium- to medium-dark-gray, very fine to fine-grained, many dark grains, silty, siliceous, slightly dolomitic, some pyrite, trace of glauconite; tight

Shale, as above; siliceous in upper and lower parts .... $\quad 10,366-10,395$

Shale, brownish-gray, slightly limy; microfossils ...... 10,395-10,410

Shale, medium-gray, silty, may be bentonitic, 
Tertiary System-Continued

Miocene Series-Continued

Temblor Formation-Continued

Carneros Sandstone Member-Continued

Second Carneros sand-Continued

slightly micaceous; may be caving

Depth

$(f t)$

Shale, dark-brownish-gray, slightly limy, silty in part; few Foraminifera

$10,410-10,413$

$10,413-10,430$

Third Carneros sand:

Sandstone, light-gray, very fine to fine-grained, scattered medium grains, very silty, slightly limy, common glauconite; probably fair porosity. Sidewall cored at 10,432 and 10,434 (no recovery at 10,434)

Shale, medium-gray

$10,430-10,435$

$10,435-10,436$

Sandstone, as above, limy. Sidewall cored at 10,437 ..

Sandstone, light-gray, very fine to medium-grained, scattered coarse grains, subangular, many dark grains, very silty, trace of glauconite; fairly good porosity. Sidewall cored at 10,441

$10,436-10,440$

$10,440-10,444$

Santos Shale Member:

Shale, medium-dark- to dark-gray, slight brownish tint in part, mostly silty, slightly to moderately siliceous; some Foraminifera in part

Shale, dark-brownish-gray, slightly limy; common Foraminifera. Probably interbedded with shale as above

Dolomite, dark-brownish-gray, very fine grained, argillaceous, hard; few microfossils (probably Foraminifera); white crystalline dolomite in fractures

Shale, as above

Sandstone, light- to medium-light-gray, very fine to fine-grained, some medium grains, silty, siliceous, slightly limy and glauconitic; probably low porosity ..

Shale, dark-brownish-gray to medium-dark-gray, probably siliceous in part, slightly limy in part; microfossils

Shale, as above. May include beds of dolomite similar to that at 10,507 to 10,510

Siltstone, medium-dark-gray, very finely sandy, slightly limy

Sandstone, medium-gray, very fine to fine-grained, silty, slightly limy and glauconitic; tight

Shale, medium-dark- to dark-gray, slight brownish tint in part, silty, slightly to moderately siliceous, slightly dolomitic; sparse to abundant microfossils ....

$10,570-10,592$

Dolomite, medium-dark-gray, slight brownish tint, very fine grained, very argillaceous, few to abundant very fine and fine sand grains, hard; tight; white calcite in fractures

Shale, light-gray, flaky, may be bentonitic; may be caving

Shale, medium-dark- to dark-gray, slightly to 
Tertiary System-Continued

Miocene Series-Continued

Temblor Formation-Continued

Santos Shale Member-Continued

moderately siliceous, slightly limy, silty and sandy

at top; scattered to abundant microfossils

$10,600-10,620$

Shale, dark-gray to dark-brownish-gray, slightly limy and siliceous; fairly common microfossils, Foraminifera. Sidewall cored at 10,620

Shale, dark-gray, silty, siliceous, slightly limy

$10,635-10,642$

Dolomite, dark-brownish-gray, very fine grained, very argillaceous, hard, trace of glauconite in part; white calcite in fractures and vugs

Shale, medium-gray, silty, slightly micaceous; calcite in fractures

$10,642-10,647$

Dolomite, as above

$10,647-10,657$

$10,657-10,662$

Shale, medium-dark-gray, silty, slightly siliceous; few microfossils

$10,662-10,670$

Shale, medium-dark- to dark-gray, silty, slightly siliceous and micaceous; few microfossils. Sidewall cored at 10,670

$10,670-10,684$

Shale, medium-dark-gray, slight brownish tint, slightly limy; microfossils

Electrical-log interpretation; no circulation samples at total depth

Estimated sample lag-10 ft.

Shale, as above

$10,684-10,690$

$10,690-10,700$

Total depth

$10,690-10,700$

10,700

\section{WELL 555_30R}

[2,381 ft north, 2,239 ft west of SE. cor. sec. 30, T. 30 S., R. 23 E.]

(Modified from $\log$ by E. E. Glick)

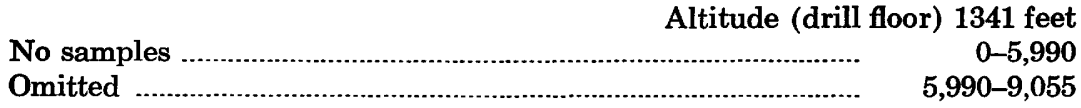

Miocene Series:

Temblor Formation:

Media Shale Member:

Well cuttings. Shale, medium-dark-gray, siliceous, massive, hard; little or no banding

Well cuttings. Shale, as above; calcite crystals

Cored $6 \mathrm{ft}$, recovered $5 \mathrm{ft}$ ( 2 trays)

Shale, medium-dark-gray, siliceous, massive, hard; 9,094-9,100

little or no banding; Foraminifera and "mud pectens"; slickensides, fracture fillings of dolomite, calcite, and pyrite; (reported dip $40^{\circ}-45^{\circ}$ )

Tray 1

Shale, similar to above

Well cuttings. Shale, dull medium-dark-gray, siliceous, Tray 2 very slightly limy, hard; trace of diatomaceous siltstone laminae; Foraminifera (especially in lower part)

Cored $8 \mathrm{ft}$, recovered $5 \mathrm{ft}$ ( 2 trays)

Shale, medium-dark-gray, slightly phosphatic, slightly 
Miocene Series-Continued

Temblor Formation-Continued

Media Shale Member-Continued

.limy to limy, hard; 1-in. bed of light-olive-gray silt-

stone in upper $1 \mathrm{ft}$ of core; Foraminifera, fish debris;

(reported dip $42^{\circ}-46^{\circ}$ )

Tray 1

Shale, similar to above; some slickensides

Tray 2

Well cuttings. Shale, medium-dark-gray, slightly limy

and phosphatic, hard; trace of Foraminifera

$9,204-9,260$

Carneros Sandstone Member:

First Carneros sand 9,260-9,348:

Drilled. No samples (probably sandstone)

9,260-9,270

Cored $7 \mathrm{ft}$, recovered $2 \mathrm{ft}$ ( 1 tray)

Sandstone, medium-light-gray, very fine to finegrained, silty, slightly limy; medium-gray clayey micaceous silty layers, micro-graded bedding; (reported $\operatorname{dip} 35^{\circ}-40^{\circ}$ )

Tray 1

Cored $12 \mathrm{ft}$, recovered $4 \mathrm{ft}$ ( 2 trays)

9,277-9,289

Sandstone, medium-light-gray, fine-grained, scattered medium grains, very silty, micaceous, slightly limy; 30 percent medium-gray limy very fossiliferous phosphatic silty siliceous shale; abundant "pellets" and Foraminifera in hard silty clay matrix; fracture fillings of light-brown silica and dolomite; (reported dip $30^{\circ}-60^{\circ}$ )

Sandstone, medium-light-gray, medium-grained, some coarse grains, very silty, micaceous, slightly limy, phosphatic; 10 percent dark-gray shale, partly laminated with fine-grained sandstone

Cored $14 \mathrm{ft}$, recovered $101 / 2 \mathrm{ft}$ ( 4 trays)

Sandstone, medium-light-gray, very fine to mediumgrained, scattered coarse grains, very silty, micaceous, slightly limy and phosphatic; 20 percent dark-gray shale in laminae showing pinch and swell features and some load casts; (reported average dip about $35^{\circ}$ )

Sandstone, similar to above; 5 percent shale as above

Sandstone, similar to above; somewhat banded with each sand layer different in grain size; shale laminae more closely spaced than above

Tray 1

Sandstone, medium-light-gray, very fine to coarsegrained, poorly sorted, limy; silt and carbonate matrix; trace of shale in "banded" pieces

Cored $2 \mathrm{ft}$, recovered $1 \mathrm{ft}$ ( 1 tray)

Sandstone, light-gray, very fine to fine-grained, silty, limy, slightly phosphatic

Cored $10 \mathrm{ft}$, recovered $8 \mathrm{ft}$ ( 3 trays)

Sandstone, as above: medium-grained in part; (reported $\operatorname{dip} 30^{\circ}-40^{\circ}$ )

Sandstone, similar to above; some very coarse grains and small pebble-sized shell fragments near base; good evidence of graded bedding associatd with a few shale laminae

Tray 1

Tray 2

Tray 3

Tray 4 9,303-9,305

Tray 1

9,305-9,315

Tray 1

Tray 2 
Miocene Series-Continued

Temblor Formation-Continued

Carneros Sandstone Member-Continued

First Carneros Sand-Continued

Sandstone, medium-light-gray, very fine to finegrained, trace of medium and coarse grains, very silty, poorly sorted, limy

Cored $19 \mathrm{ft}$, recovered $11 \mathrm{ft}$ (4 trays)

9,315-9,334

Sandstone, medium-light-gray, fine- to mediumgrained, scattered coarse and very coarse grains, silty, limy; trace of dark-gray micaceous shale laminae; (reported dip $30^{\circ}-45^{\circ}$ )

Tray 1

Sandstone, medium-light-gray to medium-gray, very fine to medium-grained, scattered coarse grains, silty, limy (especially in darker part), micaceous; trace of shale laminae

Sandstone, similar to above; more coarse grains Sandstone, similar to above; no shale laminae

Cored $14 \mathrm{ft}$, recovered $10 \mathrm{ft}$ (4 trays)

Sandstone, light-brownish-gray, very fine to medium-grained, trace of coarse grains, silty, limy, clayey; partings of dark-gray micaceous slightly phosphatic silty shale; (reported dip $50^{\circ}-60^{\circ}$ )

Sandstone, similar to above; no shale

Sandstone, similar to above; shale laminae showing pinch and swell features and some load casts

Sandstone, light-brownish-gray, very fine to mediumgrained, scattered coarse grains, silty, very clayey, slightly limy, friable; trace of dark-gray shale partings

Cored $6 \mathrm{ft}$, recovered $6 \mathrm{ft}$ ( 2 trays)

Shale, medium-dark-gray, very silty, finely sandy, slightly limy, phosphatic, hard; lenses and laminae of clayey fine-grained sandstone; (reported dip $45^{\circ}-50^{\circ}$ )

Shale, similar to above; probably more sandstone than above

Tray 1

Cored $5 \mathrm{ft}$, recovered $5 \mathrm{ft}$ ( 2 trays)

Shale, medium-dark-gray, slightly limy, phosphatic; 30 percent contorted laminae or beds of siltstone and sandstone; each bed has a different grain size (very fine to medium). Distortion of laminae indicates soft-sediment deformation

Shale, similar to above

Cored $4 \mathrm{ft}$, recovered $2 \mathrm{ft}$ ( 1 tray)

Shale, as above; some dark-gray shale with conchoidal fracture; Foraminifera; (reported dip $50^{\circ}-55^{\circ}$ )

Tray 1

Tray 2

Tray 3

Tray 3

Tray 4

9,334-9,348

Tray 4

9,348-9,354

Drilled, no samples

Cored $8 \mathrm{ft}$, recovered $2 \mathrm{ft}$ ( 1 tray)

Shale and sandstone, as above; plant fragments, fish scales, Foraminifera; (reported dip $40^{\circ}-45^{\circ}$ )

Tray 1

Tray 2

9,359-9,363

Tray 1

9,363-9,366

9,366-9,374

Tray 1 
Miocene Series-Continued

Temblor Formation-Continued

Carneros Sandstone Member-Continued

First Carneros sand-Continued

Cored $1 \mathrm{ft}$, recovered $1 \mathrm{ft}$ ( 1 tray)

9,374-9,375

Shale, medium-dark-gray to brownish-black, limy, phosphatic; laminae and fine bands; trace of siltstone and very fine to medium-grained sandstone laminae; (reported dip $40^{\circ}$ )

Tray 1

Drilled, no samples

Cored $21 \mathrm{ft}$, recovered $13 \mathrm{ft}$ (5 trays)

Second Carneros sand 9,403-9,561:

Shale, as above; interbedded with and grading into 40 percent limy slightly phosphatic very fine to medium-grained sandstone; sandstone dikes; (reported $\operatorname{dip} 30^{\circ}-40^{\circ}$ )

Tray 1

Tray 2

Shale and sandstone, similar to above

Shale and sandstone, similar to above; at least $\mathbf{5 0}$ percent sandstone; sandstone dike cuts about 5 in. of core

Tray 3

Shale, dark-gray to brownish-black, silty, slightly limy and phosphatic; 20 percent sandstone as above

Shale, similar to above; trace of fish scales, Foraminifera, and "mud pectens"

Cored $16 \mathrm{ft}$, recovered $15 \mathrm{ft}$ (5 trays)

Shale, dark-gray to brownish-black, silty, slightly limy and phosphatic; Foraminifera; interbedded with 60 percent medium-light-gray limy clayey silty very fine to medium-grained sandstone

Tray 1

Shale, similar to above; about 10 percent sandstone as above; (reported dip $40^{\circ}-45^{\circ}$ )

Sandstone, similar to above; about 10 percent shale as above

Sandstone, similar to above; about 30 percent shale as above

Shale, brownish-black, silty, slightly limy and phosphatic; Foraminifera, "mud pectens"

Cored $30 \mathrm{ft}$, recovered $21 \mathrm{ft}$ ( 7 trays)

Shale, as above; contorted interbeds of siltstone and very fine grained sandstone (40 percent) ; Foraminifera; (reported dip $40^{\circ}-45^{\circ}$ )

Sandstone, medium-gray, very fine to fine-grained, clayey, micaceous, slightly limy; laminae and beds of dark-gray shale ( 50 percent); hint of graded bedding

Sandstone, medium-light-gray, very fine to mediumgrained, some coarse grains, silty, limy, very clayey; trace of dark-gray shale laminae, contorted beds

Shale, medium-dark-gray, silty; trace of siltstone and sandstone laminae. Contortion of beds includes boudinage structures and associated pull-apart 
Miocene Series-Continued

Temblor Formation-Continued

Carneros Sandstone Member-Continued

Second Carneros sand-Continued structures, load casts, plastic flowage, and mixing ..

Sandstone, medium-light-gray, very fine to mediumgrained, silty, limy, clayey

Shale, as above; 30 percent sandstone and siltstone as above; contorted beds as above

Tray 5

Shale, as above; 50 percent siltstone and limy sandstone as above

Tray 6

Tray 7

Cored $24 \mathrm{ft}$, recovered $12 \mathrm{ft}$ (4 trays)

Sandstone, medium-light-gray, very fine to mediumgrained, silty, limy, slightly glauconitic, micaceous, clayey; 30 percent medium-dark-gray shale.

Chaotic structure suggests sediment flow-mixing shale "blocks" into sandstone matrix; (reported $\operatorname{dip} 35^{\circ}-50^{\circ}$ )

Tray 1

Siltstone, medium-gray, sandy, clayey, slightly limy; beds of clayey fine- to medium-grained sandstone; pull-apart, boudinage, and flow structures

Sandstone, medium-light-gray, very fine to finegrained, trace of medium grains, poorly sorted, very clayey; trace of medium-dark-gray shale; contorted bedding

Sandstone, as above; 35 percent dark-gray shale; contorted bedding

Cored $26 \mathrm{ft}$, recovered $28 \mathrm{ft}$ ( $2 \mathrm{ft}$ over-recovery) (10 trays)

Shale, dark-gray, silty, slightly limy and phosphatic; 40 percent brownish-gray very fine to mediumgrained limy clayey sandstone; (reported dip $45^{\circ}$ )

Sandstone, as above; some coarse grains; 30 percent shale as above; fine banding in sandstone and shale beds, contorted bedding

Sandstone, as above; mostly very fine to fine-grained; 30 percent shale as above

Tray 2

Tray 3

Tray 4

$9,476-9,502$

Tray 1

Tray 2

Tray 3

Shale, siltstone, and sandstone in about equal amounts; graded bedding

Tray 4

Sandstone, medium-light-gray, fine- to coarsegrained, limy, clayey

Tray 5

Tray 6

Sandstone, medium-light-gray, very fine to mediumgrained, scattered coarse grains, silty, limy, clayey, micaceous, trace of glauconite; some sandstone pieces have little cement left after acid treatment, others are clayey and silty

Sandstone, similar to above

Sandstone, as above; many dark-gray shale laminae (probably 5 percent of sample)

Cored $23 \mathrm{ft}$, recovered $18 \mathrm{ft}$ (6 trays)

Sandstone, as above; thin contorted shale laminae.

Dull brownish-gray silty dolomite in two beds ( 5 


\section{Miocene Series-Continued}

\section{Temblor Formation-Continued}

Carneros Sandstone Member-Continued

Depth

Second Carneros sand-Continued

and $2 \mathrm{~cm}$ thick) in lower part of core; (reported

dip about $45^{\circ}$ )

Tray 1

Sandstone, as above; trace of shale laminae

Tray 2

Sandstone, light-gray, very fine to medium-grained, scattered coarse grains, silty, limy, micaceous, clayey, slightly glauconitic

Tray 3

Sandstone, similar to above; 5 percent dark-gray slightly phosphatic shale laminae

Tray 4

Sandstone, similar to above; contorted shale bed $(1 / 2$ in. thick) near middle of core

Tray 5

Sandstone, light-brownish-gray, very fine to mediumgrained, scattered coarse grains, silty, limy to very limy, slightly dolomitic and glauconitic, clayey. The brown part of sandstone has more carbonate and less clay in cement

Tray 6

Drilled, no sample

Cored $13 \mathrm{ft}$, recovered $8 \mathrm{ft}$ ( 3 trays)

Sandstone, as above (10 percent); grades through brownish-gray limy phosphatic very clayey and silty sandstone into silty medium-dark-gray phosphatic shale; (reported dip $40^{\circ}$ )

Sandstone, similar to above; light-gray in large part; 40 percent medium-dark-gray silty sandy shale ......

Sandstone, light-gray, very fine to medium-grained, silty, limy, clayey; trace of dark-gray silty shale ....

Cored $13 \mathrm{ft}$, recovered $13 \mathrm{ft}$ (5 trays)

Sandstone, medium-light-gray, medium- to coarsegrained, trace of very coarse grains, limy to very limy, glauconitic, slightly silty and clayey; coarser grained, more limy (falls apart in acid), and less clayey than most sandstone above; trace of darkgray silty shale

Tray 1

Sandstone, similar to above; no shale

Tray 2

Sandstone, similar to above; finer grained, less limy, and more clayey

Tray 3

Sandstone, as above

Trays 4, 5

Cored $8 \mathrm{ft}$., recovered $8 \mathrm{ft}$. ( 3 trays)

9,553-9,561

Sandstone, medium-light-gray, very fine to mediumgrained, silty, slightly limy, very clayey; trace of glauconite; (reported dip $40^{\circ}-45^{\circ}$ )

Tray 1

Sandstone, as above; grades into medium-gray very clayey silty fine- to medium-grained sandstone; trace of silty shale. Contorted bedding includes folds, boudinage structures, pull-aparts, and flow structures

Sandstone, light-gray, very fine to fine-grained, limy, clayey; 25 percent medium-dark-gray silty shale 
Miocene Series-Continued

Temblor Formation-Continued

Santos Shale Member:

Cored $10 \mathrm{ft}$., recovered $10 \mathrm{ft}$. ( 4 trays)

Shale, medium-dark-gray, silty, slightly limy, phosphatic, hard, diatomaceous (?), finely banded in more silty part; trace of calcite as fracture fillings; (reported dip $40^{\circ}-45^{\circ}$ )

Tray 1

Tray 2

Shale, similar to above; more siltstone laminae

Tray 3

Shale, medium-dark-gray, silty, limy, dolomitic, slightly phosphatic, hard; many calcareous

Foraminifera(?) and diatoms(?) showing slight preferred orientation, fish scales; hint of

fine banding

$\mathbf{9 , 5 6 1 - 9 , 5 7 1}$

Cored $13 \mathrm{ft}$., recovered $12 \mathrm{ft}$. (5 trays)

Tray 4

9,571-9,584

Shale, as above; Foraminifera; 10 percent medium. light-gray limy siltstone; (reported dip $40^{\circ}$ )

Tray 1

Shale, similar to above; trace of siltstone laminae

Tray 2

Shale, dark-gray to brownish-black, siliceous, silty in part, slightly limy and phosphatic; trace of

Foraminifera

Tray 3

Tray 4

Shale, similar to above

Shale, similar to above; 20 percent medium-light-gray limy siltstone

Tray 5

Cored $24 \mathrm{ft}$., recovered $24 \mathrm{ft}$. (13 trays)

Shale, medium-dark-gray to dark-gray, silty, siliceous, limy, hard; 20 percent medium-light-gray very finely sandy siltstone in graded beds; medium sand-sized Foraminifera abundant, especially at base of siltstone layers

Tray 1

Shale, similar to above

Shale, similar to above; 40 percent siltstone; trace of fractured dolomitic limy material (may be limestone or fracture fillings)

Shale, similar to above; 45 percent siltstone; graded laminations of siltstone and shale well developed; trace of Foraminifera

Tray 4

Tray 5

Shale, similar to above; more than half siltstone; many large Foraminifera

Tray 6

Shale, medium-dark-gray, silty, limy; about 50 percent finely sandy limy slightly bentonitic siltstone; slickensides associated with bentonitic material

Bentonite, medium-light-gray to medium-gray, silty, limy in part, medium soft, slickensided; trace of light-olive-gray limy fine- to medium-grained sandstone

Tray 8

Shale, medium-dark-gray, silty, limy; interlaminated with 40 percent siltstone

Tray 9

Bentonite, medium-light-gray, silty, slightly micaceous, nonlimy, very slightly phosphatic, slightly banded to massive; slickensides (with gypsum). Bentonite forms gel in water. 
Miocene Series-Continued

Temblor Formation-Continued

Santos Shale Member-Continued

Depth

Siltstone, medium-light-gray, very finely sandy, slightly limy, phosphatic, finely micaceous; interlaminated with (finely banded in part) medium-dark-gray phosphatic shale; trace of fish debris

Siltstone, as above; 25 percent shale as above

Siltstone and shale, as above; slightly phosphatic ..........

Cored $21 \mathrm{ft}$., recovered $21 \mathrm{ft}$. (7 trays)

Shale, medium-dark-gray to brownish-black, slightly limy, micaceous; 10 percent medium-light-gray siltstone in graded laminae; (reported average dip $45^{\circ}$ )

Shale, similar to above; many large $(0.5-1.0 \mathrm{~mm})$ Foraminifera

Shale, similar to above; more limy

Shale, medium-dark-gray, silty, limy, phosphatic; interbedded with 30 percent medium-gray limy very finely sandy siltstone; fish scales

Shale, medium-dark-gray to brownish-black, silty, slightly limy, finely micaceous; trace of olive-gray siltstone laminae (1-5 mm thick) that have sharp bases and grade upward into shale

Tray 5

Shale, similar to above; about 40 percent siltstone

Shale, similar to above; very silty; about 30 percent siltstone; trace of plant fragments

Tray 6

Tray 7

Cored $24 \mathrm{ft}$., recovered $24 \mathrm{ft}$. (10 trays)

Shale, as above; about 20 percent siltstone in contorted laminae; (reported dip $35^{\circ}-45^{\circ}$ )

Shale, medium-dark-gray to brownish-gray, silty, slightly limy and phosphatic; interlaminated with 5-10 percent medium-gray siltstone; trace of large $(1.0 \mathrm{~mm})$ Foraminifera

Shale, similar to above; 30 percent siltstone as above .... Shale, similar to above; 10 percent siltstone as above .... Shale, similar to above; 30 percent very finely sandy siltstone to very fine grained sandstone

Shale, medium-dark-gray, sil.ty, slightly limy to limy, slightly phosphatic, hard; Foraminifera

Shale, similar to above; limy to very limy; fish debris ....

Shale, similar to above. After acid treatment resembles massive diatomaceous siltstone (diatomite)

Shale, similar to above; more silty; some siltstone laminae

9,629-9,653

Tray 1

Tray 11
Tray 12

Tray 13

9,608-9,629

Tray 1

Tray 2

Tray 3

Tray 4

Shale, medium-dark-gray to brownish-black, silty, limy, phosphatic, hard; Foraminifera, trace of fish debris ..

Cored $13 \mathrm{ft}$., recovered $13 \mathrm{ft}$. (5 trays)

Shale, as above; (reported dip $40^{\circ}-45^{\circ}$ )

Shale, similar to above; one very thin-shelled pelecypod (questionable "mud pecten"), abundant

Foraminifera

Tray 2

Tray 3

Tray 4

Tray 5

Tray 6

Tray 7

Tray 8

Tray 9

Tray 10

9,653-9,666

Tray 1

Tray 2 
Miocene Series-Continued

Temblor Formation-Continued

Santos Shale Member-Continued

Shale, similar to above; more clayey; abundant

Foraminifera

Shale, similar to above; more silty; fewer

Foraminifera, questionable diatoms

Tray 3

Tray 4

Shale, similar to above; very limy; some siliceous

Foraminifera and (or) diatoms. After acid

treatment rock is brownish-gray, porous;

resembles reworked diatomaceous siltstone

(diatomite)

Tray 5

Cored $6 \mathrm{ft}$., recovery unknown (2 trays)

$9,666-9,672$

Shale, medium-dark-gray, silty, slightly limy, phosphatic, finely micaceous, hard; trace of Foraminifera

Shale, similar to above; more limy, more microfossils ..

Note: Correct depth from (under-hole)

Cored $9 \mathrm{ft}$., recovered $8 \mathrm{ft}$. ( 3 trays)

Shale, medium-dark-gray to brownish-gray, silty, slightly limy, phosphatic, hard; trace of microfossils; (reported $\operatorname{dip} 45^{\circ}$ )

Shale, similar to above; many fish scales

Shale, similar to above; fish scales; may be reworked diatomaceous siltstone (diatomite)

Tray 1

Tray 2

9,672-9,663

$\mathbf{9 , 6 3 3 - 9 , 6 7 2}$

Drilled, no samples

Cored $25 \mathrm{ft}$., recovered $25 \mathrm{ft}$. (10 trays)

Shale, as above; includes several light-brown limy very phosphatic questionably organic masses that may be as large as 1 in. in diameter (may be bone); (reported $\operatorname{dip} 40^{\circ}-45^{\circ}$ )

Tray 1

Shale, medium-dark-gray, silty, limy, phosphatic, hard; trace of siltstone laminae; microfossils, fish debris ....

Shale, similar to above

Shale, similar to above; 10 percent siltstone

Shale, similar to above; little or no siltstone

Tray 1

Tray 2

Tray 3

9,672-9,685

$9,685-9,710$

Shale, similar to above; about 10 percent siltstone, graded laminae in part

Shale, medium-gray, silty, slightly limy and phosphatic, micaceous; 20 percent medium-lightgray very finely sandy siltstone

Tray 2

Tray 3

Tray 4

Tray 5

Tray 6

Tray 7

Shale, similar to above; much fine silt (probably reworked diatoms), slightly limy; 10 percent medium-light-gray siltstone laminae; Foraminifera, fish debris

Tray 8

Shale, similar to above

Tray 9

Shale, similar to above; 20 percent siltstone as above showing graded bedding

Tray 10

Well cuttings; shale, as above

9,710-9,739

Cored $25 \mathrm{ft}$., recovered $25 \mathrm{ft}$. (12 trays)

$9,739-9,764$

Shale, medium-dark-gray, silty, limy, phosphatic; (reported $\operatorname{dip} 45^{\circ}$ )

Tray 1

Shale, medium-gray, silty, slightly limy and 
Miocene Series-Continued

Temblor Formation-Continued

Santos Shale Member-Continued phosphatic, hard

Depth

(ft)

Shale, similar to above; trace of siltstone laminae

Tray 2

Shale, medium-dark-gray, silty, slightly limy,

Tray 3 phosphatic, hard, probably diatomaceous; microfossils

Shale, similar to above

Shale, similar to above; trace of siltstone laminae

Shale, medium-dark-gray, silty, slightly limy, micaceous, phosphatic, hard

Shale, similar to above; microfossils

Shale, medium-dark-gray, silty, limy, slightly phosphatic, hard; Foraminifera, fish scales

Shale, similar to above

Drilled, no samples

Cored $23 \mathrm{ft}$., recovered $23 \mathrm{ft}$. (10 trays)

Shale, medium-dark-gray, limy, slightly phosphatic, silty, hard, probably diatomaceous; Foraminifera; (reported dip $40^{\circ}-45^{\circ}$ )

Tray 4

Tray 5

Tray 6

Tray 7

Tray 8

Tray 9

Trays 10-12

9,764-9,786

9,786-9,809

Shale, similar to above

Shale, similar to above; 10 percent phosphatic limy micaceous siltstone laminae; pull-apart structures ....

Shale, similar to above; trace of siltstone

Shale, similar to above; 10 percent siltstone, some contorted beds

Shale, similar to above; 10 percent siltstone

Shale, similar to above; 20 percent very finely sandy siltstone; trace of "mud pectens"

Siltstone, medium- to medium-dark-gray, very finely sandy, limy, phosphatic, micaceous, clayey; contorted beds and pull-apart structures; 50 percent shale as above

Shale, medium-dark-gray, silty, limy, slightly phosphatic, hard

Drilled, no samples

Cored $18 \mathrm{ft}$., recovered $10 \mathrm{ft}$. (4 trays)

Shale, medium-dark-gray, silty, slightly limy to limy, slightly phosphatic, hard; microfossils; (reported dip about $45^{\circ}$ )

Shale, similar to above

Shale, similar to above but darker; many Foraminifera, trace of "mud pectens"

Shale, similar to above; nearly 10 percent silty very fine grained sandstone (laminae or burrow fillings) ..

Drilled, no samples

Cored $21 \mathrm{ft}$., recovered $16 \mathrm{ft}$. (6 trays)

Shale, medium-dark-gray, silty, limy, phosphatic, micaceous; 20 percent medium-light-gray limy micaceous siltstone laminae that grade upward into shale; Foraminifera; (reported dip about $40^{\circ}$ )

Tray 1

Trays 2,3

Tray 4

Tray 5

Tray 6

Tray 7

Tray 8

Tray 9

Tray 10

9,809-9,824

$9,824-9,842$

Tray 1

Tray 2

Tray 3

Tray 4

9,842-9,852

9,852-9,873

Tray 1 
Miocene Series-Continued

Temblor Formation-Continued

Santos Shale Member-Continued

burrow fillings; large $(1 \mathrm{~mm})$ Foraminifera

Depth

(ft)

Shale, medium-dark- to dark-gray, silty, limy,

slightly phosphatic, micaceous; Foraminifera

Tray 2

Shale, similar to above; fish scales

Tray 3

Tray 4

Shale, medium-dark-gray, very silty, limy, slightly phosphatic, micaceous, hard; fish scales and vertebrae

Shale, similar to above; much fine silt (probably cryptocrystalline quartz derived from diatoms)

Tray 5

Well cuttings. Shale, similar to above

Tray 6

9,873-9,936

Cored $16 \mathrm{ft}$., recovered $9 \mathrm{ft}$. (3 trays)

9,936-9,952

Shale, medium-gray, silty, limy, slightly phosphatic, micaceous; trace of siltstone laminae; fish debris, Foraminifera; (reported dip $30^{\circ}-40^{\circ}$ )

Tray 1

Shale, medium-dark-gray, silty, slightly limy to limy, slightly phosphatic, probably diatomaceous;

Foraminifera

Shale, as above; 40 percent medium-light-gray siltstone laminae

Well cuttings. Shale, medium-dark-gray, silty, slightly limy and phosphatic, probably diatomaceous; many Foraminifera

Cored $11 \mathrm{ft}$., recovered $9 \mathrm{ft}$. (3 trays)

Shale, medium-gray, silty, limy, slightly phosphatic, hard, diatomaceous (?), Foraminifera; (reported dip $45^{\circ}$ )

Tray 1

Shale, similar to above; trace of siltstone

Trays 2,3

Well cuttings.

Shale, medium-dark-gray, silty, limy, slightly phosphatic; many microfossils. Residue from acid looks like diatomaceous siltstone (diatomite)

10,034-10,148

Cored $8 \mathrm{ft}$., recovered $2 \mathrm{ft}$. (1 tray) $10,148-10,156$

Shale, medium-gray, very silty, slightly limy and phosphatic; much silt (questionable diatoms) and much clastic siltstone. Unit probably grades downward into siltstone; (reported dip 55 $5^{\circ}$ )

Well cuttings. Silty shale, as above

Shale, similar to above; dark-brownish-gray very dolomitic siltstone or silty dolomite; tiny "spicules" ..

$10,180-10,210$

Shale, medium-dark-gray, silty, slightly limy to dolomitic; diatomaceous (?); interbedded with medium-light-gray limy to dolomitic glauconitic silty very fine to fine-grained sandstone with trace of medium grains; trace of dark-brownish-gray limy silty dolomite

Cored $15 \mathrm{ft}$., recovered $4 \frac{1}{2} \mathrm{ft}$. ( 2 trays)

Sandstone, medium-light-gray, very fine to finegrained, scattered medium grains, silty, very limy, dolomitic, pyritic, glauconitic, clayey; (reported dip $50^{\circ}$ )

Shale, medium-gray, silty, slightly limy to limy (may be dolomitic), slightly phosphatic, even- 
Miocene Series-Continued

Temblor Formation-Continued

Santos Shale Member-Continued

grained and hard (may be diatomaceous); trace

of Foraminifera

Depth

(ft)

Drilled, no sample

Cored $25 \mathrm{ft}$., recovered $18 \mathrm{ft}$. (7 trays)

Tray 2

Shale, as above; pyrite, Foraminifera; (reported dip about $45^{\circ}$ )

Shale, similar to above

Shale, medium-gray, silty, slightly limy or dolomitic, slightly phosphatic, hard, even-grained; trace of fish debris and Foraminifera

Shale, similar to above; less limy in lower part

Drilled, no samples

Cored $6 \mathrm{ft}$., recovered $4 \mathrm{ft}$. (2 trays)

Shale, dull medium-dark-gray, silty, very slightly limy, slightly phosphatic, hard; (reported dip $45^{\circ}-50^{\circ}$ ) ....

Shale, similar to above; probably clayey diatomaceous siltstone (diatomite)

Well cuttings. Shale, similar to above; several pieces of brownish-gray silty dolomite (probably out of place)

Cored $6 \mathrm{ft}$., recovered $4 \mathrm{ft}$. ( 2 trays)

Shale, dull medium-dark-gray, silty, very slightly limy to nonlimy, slightly phosphatic, even-grained, hard, diatomaceous (?); trace of fish scales; (reported dip $45^{\circ}$ )

Shale, similar to above; 50 percent medium-light-gray slightly limy siltstone

Well cuttings. Shale, dark-brownish-gray, slightly limy, phosphatic; Foraminifera. In these samples there is as much as 50 percent medium-light-gray limy slightly phosphatic glauconitic silty very fine to medium-grained sandstone (may be out of place) ......

Cored $15 \mathrm{ft}$., recovered $12 \mathrm{ft}$. (5 trays)

Siltstone, medium-light- to redium-gray, dolomitic, phosphatic. Lighter colored rock is coarsest; some of the darker rock grades into very siliceous dolomite. Contorted laminae and beds; (reported dip 50 $-55^{\circ}$ )

Siltstone, similar to above; 20 percent medium-gray siltstone (questionably diatomaceous)

Siltstone, similar to above; many medium sand grains in a few lenses; 20 percent siltstone or silty shale, probably diatomaceous (diatomite)

Siltstone, medium-light-gray, very finely sandy, limy, slightly phosphatic, clayey; 20 percent brownish-gray dolomitic siltstone or silty dolomite (may be siderite), may be diatomaceous

$10,359-10,414$

$10,414-10,429$

Trays 5-7

$10,277-10,293$

$10,293-10,299$

Tray 1

Tray 2

$10,299-10,353$

$10,353-10,359$

Tray 1

Tray 2

Tray 1

Tray 2

Tray 3

Shale (or diatomite), medium-gray, silty, slightly limy and phosphatic, hard, poorly laminated

Cored $19 \mathrm{ft}$., recovered $22 \mathrm{ft}$. (3 ft. over-recovery) (9 trays)

No samples 
Miocene Series-Continued

Temblor Formation-Continued

Santos Shale Member-Continued

Depth

Shale, dull medium-gray, silty, slightly limy and

phosphatic, hard; contorted laminae; may be

diatomaceous (diatomite); trace of microfossils;

(reported $\operatorname{dip} 45^{\circ}$ to $50^{\circ}$ )

Tray 2

Shale, similar to above; trace of siltstone in discontinuous contorted beds

Tray 3

Shale, dull medium-dark-gray, silty, limy, slightly phosphatic, hard; trace of fish scales

Tray 4

Tray 5

Siltstone, dull medium-gray, slightly limy (or dolomitic) and phosphatic, clayey; some silty shale as above

Tray 6

Tray 7

Siltstone, similar to above; 50 percent silty shale

Tray 8

Shale, as tray 4; laminae of siltstone

Shale, similar to above; 15 percent medium-light-gray glauconitic fine-grained sandstone

Tray 9

Cored $16 \mathrm{ft}$, recovered $12 \mathrm{ft}$ (4 trays)

$-10,464$

Shale, dull medium-gray, silty (upper 16 in.), slightly limy and phosphatic; medium-light-gray limy slightly phosphatic glauconitic silty clayey finegrained sandstone (lower 11 in.);

(reported $\operatorname{dip} 45^{\circ}-60^{\circ}$ )

Tray 1

Sandstone, medium-light-gray, very fine to finegrained, scattered medium grains, silty, limy, slightly phosphatic, clayey

Shale, dull brownish-black, silty, slightly limy, phosphatic, more clayey than most samples above;

slickensides; fish scales

Shale, dull medium-gray to brownish-gray, silty, limy to very limy (silty limestone in part), slightly phosphatic. Residue after acid treatment looks like dull brown diatomaceous siltstone (diatomite)

Tray 4

Cored $14 \mathrm{ft}$., recovered $14 \mathrm{ft}$. (6 trays)

Siltstone, medium-light-gray, well sorted, very slightly limy; 40 percent medium-gray slightly phosphatic silty shale; (reported dip $50^{\circ}-55^{\circ}$ )

Shale, dull medium-dark-gray, silty, slightly limy and phosphatic, hard

Tray 2

Tray 3

Shale, similar to above

Siltstone, dull medium-gray, slightly limy and phosphatic, clayey; interbedded with 30 percent shale as above; slickensides

Siltstone, similar to above; trace of medium-gray clayey very fine to medium-grained sandstone

Shale, dull medium-dark-gray, silty, slightly limy, hard; trace of siltstone as above

Tray 1

Tray 2

Tray 3

Drilled, no samples

Tray 4

Tray 5

Tray 6

Cored $9 \mathrm{ft}$., recovered $2 \mathrm{ft}$. (1 tray)

Siltstone, dull medium-light- to medium-gray, slightly limy, phosphatic, clayey; grades into medium-dark- 
Miocene Series-Continued

Temblor Formation-Continued

Santos Shale Member-Continued

Depth

gray phosphatic shale; fish scales;

(reported $\operatorname{dip} 30^{\circ}-40^{\circ}$ )

Tray 1

Well cuttings. Mostly shale similar to above; some dark-gray phosphatic shale; some siltstone as above

Cored $6 \mathrm{ft}$., recovered $4 \mathrm{ft}$. ( 2 trays)

Siltstone, dull medium-light- to medium-gray, slightly limy and phosphatic, clayey; laminae and stringers of medium-dark-gray shale; (reported dip $40^{\circ}-45^{\circ}$ )

Siltstone, medium-light-gray, very finely sandy, slightly limy and phosphatic, clayey; trace of darkgray shale; dull earthy brownish-gray silty dolomite (probably nodules)

Well cuttings. Shale, medium-dark-gray, silty, slightly limy; laminae of medium-gray siltstone and mediumlight-gray silty very fine grained sandstone; trace of Foraminifera

Cored $7 \mathrm{ft}$., recovered $5 \mathrm{ft}$. ( 2 trays)

Shale, dull dark-brownish-guay, very silty, slightly limy (or dolomitic) and phosphatic; 10 percent mediumgray siltstone laminae

Shale, as above; 30 percent siltstone as above; very little lime in shale

Well cuttings. Shale as above; some siltstone and sandstone; slickensides, some fracture-filling

Dolomite, dull brownish-gray, very limy, clayey, siliceous, fractured in part

Shale, dull medium-dark-gray, very silty

Cored $8 \mathrm{ft}$., recovered $4 \mathrm{ft}$. (2 trays)

Dolomite; medium-light-gray, limy, silty, clayey, finely granular to dense; fractures filled with clear calcite; 10 percent medium-light-gray finely sandy siltstone; (reported dip about $40^{\circ}$ )

Sandstone, medium-light-gray, very fine to mediumgrained, silty, slightly dolomitic to dolomitic, clayey; 10 percent dolomite as above

Well cuttings. Sandstone, light- to medium-light-gray (some "salt and pepper"), very fine to fine-grained, scattered medium grains, silty, limy, slightly dolomitic, clayey; interbedded with medium-darkgray silty shale

Sandstone and shale, as above; 10 percent mediumlight-gray to light-brownish-gray dense dolomite

Sandstone, medium-light-gray, very fine to finegrained, medium grains in part, silty, dolomitic, slightly glauconitic; interbedded with dark-gray silty shale

Cored $9 \mathrm{ft}$., no recovery

Cored $13 \mathrm{ft}$., recovered 15 feet ( $2 \mathrm{ft}$. over-recovery) (5 trays) 
Miocene Series-Continued

Temblor Formation-Continued

Santos Shale Member-Continued

of medium grains, silty, limy, dolomitic, clayey, glauconitic, much light-gray matrix - may be dolomitic clay (may be largely of volcanic origin); 50 percent medium-gray dolomitic slightly phosphatic shale and siltstone; fish scales; (reported $\operatorname{dip} 45^{\circ}-50^{\circ}$ )

Tray 1

No samples

Trays 2, 3

Sandstone, similar to above; more siltstone and less sandstone; dark-gray imbricated plant fragments in lower 4 in. of core

Siltstone, medium-light-gray, very dolomitic, scattered very fine sand; fish scales, plant fragments

Tray 4

Cored $8 \mathrm{ft}$., recovered $8 \mathrm{ft}$. (3 trays)

Tray 5

Siltstone, as above; (reported erratic dips $40^{\circ}-60^{\circ}$ ) ....

Siltstone, similar to above

Siltstone, similar to above; scattered very fine to medium sand $-10,823$

Tray 1

Tray 2

Tray 3

Cored $13 \mathrm{ft}$. , recovered $7 \mathrm{ft}$. ( 3 trays)

$10,823-10,836$

Siltstone, medium-light-gray, dolomitic, very clayey, slightly phosphatic, hard; many dark-gray coalified plant fragments as much as $5 \mathrm{~mm}$ long imbricated in some pieces of core; (reported dip $45^{\circ}$ )

Tray 1

Siltstone, as above; 35 percent medium-light-gray dolomitic clayey silty very fine to fine-grained sandstone; plant fragments

Tray 2

Siltstone, similar to above; 15 percent sandstone; trace of dull brownish-gray silty dolomite

Tray 3

Well cuttings. Siltstone, similar to above; darkbrownish-gray silty shale; medium-light-gray siltstone; light-gray to "salt and pepper" very fine to fine-grained sandstone; trace of dolomite

Cored $9 \mathrm{ft}$., recovered $7 \mathrm{ft}$. (3 trays) $10,901-10,910$

Shale, medium-gray, silty, slightly dolomitic and phosphatic, hard; 5 percent medium-light-gray slightly limy (or dolomitic) clayey silty very fine to coarse-grained sandstone; (reported dip 55 $5^{\circ}$ )

Tray 1

Shale, dull dark-brownish-gray to medium-dark-gray, very silty, slightly limy and phosphatic; trace of medium-light-gray very silty dolomite

Tray 2

Shale, medium- to medium-dark-gray, very silty, slightly limy; interlaminated with (graded laminae) medium-light- to medium-gray clayey dolomitic siltstone

Drilled, no samples 10,910-10,940

Shale, dark-gray; medium-light-gray ("salt and pepper") very fine to fine-grained sandstone

Siltstone, medium-light- to medium-gray, slightly limy or dolomitic, clayey; 30 percent medium-gray slightly phosphatic silty shale; (reported dip $50^{\circ}-60^{\circ}$ ) 


\section{Miocene Series-Continued}

Temblor Formation-Continued

Santos Shale Member-Continued

Shale, dull brownish-gray to brownish-black, silty, nonlimy, phosphatic; many slickensides; grades into medium-gray clayey siltstone (10 percent of sample)

Shale, dull brownish-gray, silty; slickensides; probably diatomaceous

Well cuttings. Shale, as above; slickensides, trace of fish scales; trace of dark-brownish-gray dolomite mostly in lower part of unit; medium-light-gray ("salt and pepper") very fine grained sandstone and limy fine-grained sandstone (may be caving)

Cored $6 \mathrm{ft}$., recovered $4 \mathrm{ft}$. ( 2 trays)

Shale, dull medium-dark-gray, silty, slightly limy and phosphatic, hard; trace of slickensides; a few siltstone laminae; (reported dip $50^{\circ}-55^{\circ}$ )

Shale, similar to above; contaminated sample

Well cuttings. Shale, dull dark-gray, silty; mediumlight-gray ("salt and pepper") very fine to finegrained sandstone; trace of dolomite

Shale, as above; 50 percent light-gray ("salt and pepper") very limy dolomitic pyritic very fine grained sandstone

Cored $8 \mathrm{ft}$., recovered $51 / 2 \mathrm{ft}$. ( 2 trays)

Siltstone, medium-light-gray, very dolomitic; interlaminated with (graded laminae) slightly darker more clayey less dolomitic siltstone; (reported dip $55^{\circ}-58^{\circ}$ )

Siltstone, as above; some grades into medium-gray silty shale; medium-light-gray limy clayey silty slightly glauconitic very fine to medium-grained sandstone (lower 6 in. of core)

Tray 2

Well cuttings. Shale, dark-gray; slickensides; mediumlight-gray ("salt and pepper") very fine to finegrained sandstone; trace of medium-light-gray siltstone. Poor samples

Cored $8 \mathrm{ft}$., recovered $6 \mathrm{ft}$. ( 2 trays)

Shale, dull medium-dark-gray, silty, very slightly limy, slightly phosphatic, hard; contorted laminae (pullaparts) of slightly liny siltstone; (reported dip $55^{\circ}$ )

Shale, as above; 50 percent medium-light-gray slightly limy very finely sandy siltstone in contorted graded laminae

Tray 2

Well cuttings. Shale, dull dark-gray, silty; some medium-light-gray siltstone and very fine to medium-grained sandstone.

Shale, as above; 30 percent noedium-light-gray limy clayey silty very fine to medium-grained sandstone, trace of coarse grains; plant debris

Cored $13 \mathrm{ft}$., recovered $6 \mathrm{ft}$. ( 2 trays)

Shale, dull dark-brownish-gray, silty, slightly limy and 
Miocene Series-Continued

Temblor Formation-Continued

Santos Shale Member-Continued

Depth

phosphatic, finely micaceous; trace of microfossils, plant debris; $1 \mathrm{ft}$. of medium-light-gray slightly limy clayey silty very fine to medium-grained sandstone, trace of coarse grains; (reported $\operatorname{dip} 55^{\circ}$ )

Sandstone, as above (11/2 ft.); shale as above; trace of siltstone

Cored $18 \mathrm{ft}$., recovered $13 \mathrm{ft}$. (5 trays)

Siltstone, medium-gray, sandy, clayey, slightly limy and phosphatic, scattered sand grains and one granule; laminae of dark-gray shale, probably slumped graded laminae; (reported dip $45^{\circ}$ )

Sandstone, medium-light- to medium-gray, very fine to coarse-grained (sand in mudstone matrix), very clayey, silty, slightly limy (or dolomitic) and phosphatic; interlaminated with (graded laminae) medium-dark-gray shale and medium-light-gray siltstone

Shale, medium-dark-gray to dark-brownish-gray, slightly phosphatic, finely micaceous; more of a shale fracture than most shale above

Shale, as above; 20 percent medium-light-gray slightly limy siltstone in graded laminae

Sandstone, medium-light-gray, very fine to coarsegrained, silty, limy, clayey, glauconitic; trace of contorted shale laminae

Tray 5

Cored $20 \mathrm{ft}$., recovered $8 \mathrm{ft}$. (3 trays)

Sandstone, medium-light-gray, very fine to very coarse grained, abundant subangular to subrounded grains of feldspar and rock fragments, very silty and clayey, slightly limy to limy; trace of medium-darkgray shale with siltstone laminae; (reported dip $55^{\circ}$ )

Shale, medium-dark-gray, very silty, slightly phosphatic; 20 percent sandstone as above

Tray 1

Tray 2

Shale, medium-dark-gray, silty, slightly limy and phosphatic; interbedded with light-gray siltstone; $4 \mathrm{in}$. of medium-light-gray slightly limy very clayey and silty fine- to coarse-grained sandstone at base ...

Cored $20 \mathrm{ft}$., recovered 6 feet. (2 trays)

Tray 3

Shale, medium-gray, silty, slightly limy and phosphatic, hard; interbedded with medium-lightgray slightly limy siltstone and medium-light-gray very fine to fine-grained sandstone; (reported dip $45^{\circ}-60^{\circ}$ )

Tray 1

Siltstone, medium light-gray, finely sandy, limy, clayey; interlaminated with medium-dark-gray shale, some very thin graded laminae

Cored $8 \mathrm{ft}$, recovered $3 \mathrm{ft}$ ( 1 tray)

Siltstone, as above; 20 percent shale as above; many plant fragments in each 
Miocene Series-Continued

Temblor Formation-Continued

Santos Shale Member-Continued

Depth

$(f t)$

Cored $10 \mathrm{ft}$., recovered $3 \mathrm{in}$. No samples available

Reported description:

11,326-11,326 $1 / 4$ Shale, dark-grayish-brown, silty, hard; interlaminated with gray very fine grained silty sandstone; dip about $20^{\circ}$.

$11,3261 / 4-11,336$ Lost.

Cored $12 \mathrm{ft}$., no recovery

Well cuttings. Sandstone, medium light-gray ("salt and pepper"), very fine to fine-grained, trace of coarse grains, silty, slightly limy, clayey

$11,326-11,336$

Cored $4 \mathrm{ft}$., recovered 3 in. (1. tray)

$11,336-11,348$

Sandstone, medium-light-gray ("salt and pepper"), very fine to fine-grained ( 2 in. piece), silty, slightly limy; medium-dark-gray shale

Well cuttings. Shale, medium-dark-gray, silty; 20 percent medium-light-gray ("salt and pepper") silty limy very fine to medium-grained standstone, trace of coarse grains; trace of slightly banded medium-light-gray ("salt and pepper") siltstone

Sandstone, medium-light-gray ("salt and pepper"), very fine to fine-grained, silty, limy, clayey, micaceous, glauconitic, faintly banded

Sandstone, as above; 50 percent shale, probably from above

Cored $14 \mathrm{ft}$., recovered $5 \mathrm{ft}$. ( 2 trays)

Sandstone, light-gray, very fine to coarse-grained, silty, slightly limy and dolomitic, very clayey, glauconitic, micaceous; 10 percent medium-dark-gray shale; (reported dip about $60^{\circ}$ )

Tray 1

Tray 2

Sandstone and shale, as above

Well cuttings. Sandstone, as above; 50 percent shale (may be caving)

Cored $13 \mathrm{ft}$., recovered $7 \mathrm{ft}$. (3 trays)

$11,450-11,472$

$11,472-11,486$

Sandstone, light- to medium-light-gray ("salt and pepper"), very fine to coarse-grained, very silty and clayey, limy, slightly phosphatic, glauconitic, slightly banded or laminated; (reported dip $45^{\circ}-55^{\circ}$ )

Sandstone, as above; mostly fine-grained

Tray 1

Tray 2

Sandstone, medium-light-gray, very fine to finegrained, trace of medium grains, silty, limy, clayey, slightly phosphatic

Well cuttings. Sandstone, as above; many pieces are 30 percent coarse grains

Cored $8 \mathrm{ft}$., recovered $1 / 2 \mathrm{ft}$. No samples available Reported description:

11,565-11,5651/2 Shale, dark-grayish-brown, silty, micaceous, hard; dip about $55^{\circ}$. 11,5651/2-11,573 Lost.

Well cuttings. Sandstone, as above; lower $10 \mathrm{ft}$. probably shale as below 
Miocene Series-Continued

Temblor Formation-Continued

Santos Shale Member-Continued

Depth

Cored $5 \mathrm{ft}$., recovered $3 \mathrm{ft}$. (1 tray)

$11,617-11,622$

Shale, medium-dark-gray, silty, nonlimy, slightly phosphatic; siltstone laminae;

(reported dip about $60^{\circ}$ )

Tray 1

Well cuttings. Shale, dark-gray, silty; 40 percent medium-light-gray very fine to coarse-grained sandstone (probably caving)

Cored $9 \mathrm{ft}$., recovered $3 \mathrm{ft}$. (1 tray)

Shale, dull dark-gray, silty, nonlimy, slightly dolomitic, micaceous; a few laminae of medium-gray siltstone; (reported dip $60^{\circ}-70^{\circ}$ )

Tray 1

Well cuttings. Shale, as above; interbedded with medium-light-gray ("salt and pepper") very fine to coarse-grained sandstone and medium-light-gray siltstone

Sandstone, medium-light-gray ("salt and pepper"), very fine to coarse-grained, silty; interbedded with dark-gray shale. Poor samples

Cored $9 \mathrm{ft}$., recovered $7 \mathrm{ft}$. ( 3 trays)

Siltstone, medium-light-gray, slightly limy; interlaminated with 30 percent medium-dark-gray finely micaceous slightly phosphatic silty shale; (reported $\operatorname{dip} 70^{\circ}-80^{\circ}$ )

Siltstone, medium-light-gray ("salt and pepper"), slightly limy, clayey; a few dark-gray shale partings; contorted laminae; coalified plant debris

Siltstone, medium-light-gray, very finely sandy, limy, clayey; interlaminated with (graded laminae) 40 percent medium-dark-gray shale; contorted laminae

Well cuttings. Shale, dull medium-dark-gray; some siltstone as above and trace of medium-grained sandstone. Poor samples

Cored $3 \mathrm{ft}$., recovered 11/2 ft. (1 tray)

Shale, dark-gray to olive-black, nonlimy, slightly phosphatic; questionable microspicules; (reported dip about $75^{\circ}$ )

Well cuttings. Shale, as above

Cored $6 \mathrm{ft}$., recovered $1 / 2 \mathrm{ft}$. No sample

$11,869-11,875$

Well cuttings. Shale, as above. Poor samples

$11,875-11,930$

Shale, dark-gray, slightly phosphatic; some slickensides. Poor samples

$11,930-11,950$

$11,950-11,994$

$11,994-12,000$

Cored $6 \mathrm{ft}$., no recovery

Cored $6 \mathrm{ft}$., recovered $11 \mathrm{ft}$. ( $5 \mathrm{ft}$. over-recovery) (4 trays)

Shale, medium-dark-gray, silty, nonlimy, phosphatic; may be reworked diatomaceous siltstone (diatomite); (reported dip about $75^{\circ}$ ) 
Miocene Series-Continued

Temblor Formation-Continued

Santos Shale Member-Continued

Well cuttings. Shale, as above; some slickensides; trace of light-gray siltstone and sandstone in lower part ....

Cored $13 \mathrm{ft}$., recovered $10 \mathrm{ft}$. (4 trays)

Shale, medium- to medium-dark-gray, finely micaceous, slightly phosphatic (upper $1 \mathrm{ft}$.) ; lightgray slightly limy siltstone; some finely mottled limy pyritic questionably fossiliferous siltstone; (reported dip $70^{\circ}$ )

Siltstone, light-gray, finely mottled, finely micaceous ....

Siltstone, light-gray (mottled with medium-light-gray spots), slightly limy, very finely micaceous. Siltstone crushed in clove oil, 95 percent microcrystalline, index less than oil, includes questionable shards (W. A. McCracken)

Siltstone, similar to above; slightly coarser mica

Well cuttings. Shale, dark-gray, silty; trace of sandstone. Poor samples

Casing cemented

Samples mostly pipe scale; trace of siltstone as below .. Cored $14 \mathrm{ft}$., recovered $13 \mathrm{ft}$. (5 trays)

Siltstone, pale-yellowish-brown, finely sandy, slightly limy. Siltstone crushed in clove oil, 90 percent microcrystalline, low biref ringence, trace of shards, 3-6 percent quartz and feldspar silt (W. A.

McCracken). Interbedded with medium-gray slightly phosphatic silty shale; (reported dip $60^{\circ}-65^{\circ}$ )

Shale, as above; 30 percent siltstone as above; more very fine sand

Tray 1

Tray 2

Siltstone, medium-gray, very slightly limy, slightly phosphatic; much coalified plant debris; 30 percent medium-gray silty shale

Tray 3

Tray 4

$12,075-12,100$

12,100

$12,100-12,161$

$12,161-12,175$

Tray 3

Siltstone, as above; 60 percent pale-yellowish-brown and 40 percent medium-light-gray; contains plant debris

Tray 4

Siltstone, light-gray, slightly limy; interbedded with 20 percent medium-gray silty shale; trace of plant debris

Tray 5

Cored $4 \mathrm{ft}$., recovered $5 \mathrm{ft}$. ( $1 \mathrm{ft}$. overrecovery) ( 2 trays)

Siltstone, medium-light- to light-gray, slightly limy and phosphatic, finely sandy in part; grades into and interbedded with medium-gray to olive-gray slightly limy and phosphatic hard silty shale; some medium-light-gray soft flaky bentonite(?); (reported $\operatorname{dip} 65^{\circ}$ )

Siltstone, mediurn-gray, slightly limy and dolomitic, clayey, hard, very finely sandy in part, very clayey in part; plant debris

Cored $47 \mathrm{ft}$., recovered $47 \mathrm{ft}$. (18 trays)

Siltstone, as above; 50 percent slightly darker and finer-grained, 50 percent lighter and coarser- 
Miocene Series-Continued

Temblor Formation-Continued

Santos Shale Member-Continued

Siltstone, medium-light-gray, slightly limy, clayey, hard; trace of medium-gray clayey siltstone with coalified plant fragments

Siltstone, medium-light-gray, nonlimy, very slightly phosphatic; trace of plant fragments

Tray 3

Siltstone, medium-light-gray, nonlimy to slightly limy; scattered very fine sand in some pieces of siltstone, other pieces "dense"

Siltstone, medium-light-gray, finely sandy, slightly limy (acid etches only certain grains), micaceous; trace of small structures that look organic but probably are volcanic (almost pelletal); calcareous masses (about $3 \mathrm{~mm}$ ) especially about 8 in. above base; trace of dark-gray plant fragments

Tray 5

Siltstone, similar to above; some medium "sand"; volcanic glass observed under petrographic microscope

Siltstone, medium-light-gray to yellowish-brown, slightly limy; little or no sand; dull yellowish-brown part is flaky but does not form gel in water

Tray 7

Siltstone, medium-light-gray, finely sandy, slightly limy, clayey. Some pieces of siltstone contain no sand and have a mottled "pelletal" texture; trace of plant debris

Tray 8

Siltstone, medium-light-gray, slightly limy, hard; interbedded with 50 percent medium-gray hard silty shale

Tray 9

Siltstone, medium-light- to medium-gray, very slightly limy, finely laminated in part; trace of plant debris ..

Siltstone, light-gray, slightly limy to limy (may be dolomitic)

Tray 10

Tray 11

Siltstone, medium-light-gray, slightly limy, laminated in part, very mottled and "pelletal" in part and contains alined plant fragments. Probably grades upwards into laminated siltstone in a sequence of graded beds

Tray 12

Siltstone, light-gray, limy; 30 percent medium-lightgray "dense" siltstone. Both types finely mottled

Siltstone, similar to above; trace of plant fragments. Coarser-grained beds have load casts at basal contact with finer-grained beds

Siltstone, medium-light-gray, slightly limy; grades into shale; light-yellowish-gray calcareous masses (1-3 mm); plant fragments in shale

Siltstone, light-gray, slightly limy; plant fragments; $1 \mathrm{in}$. bed of olive-gray silty shale $5 \mathrm{in}$. above base

Siltstone, light-gray, limy, slightly dolomitic; 50 percent medium-gray shale; plant debris in siltstone 
Miocene Series-Continued

Temblor Formation-Continued

Santos Shale Member-Continued

Depth

$(f t)$

Cored $20 \mathrm{ft}$., recovered $19 \mathrm{ft}$. (7 trays)

$12,226-12,246$

Siltstone, medium-light-gray, slightly limy; trace of medium-gray shale; plant fragments throughout; (reported dip $65^{\circ}-68^{\circ}$ )

Tray 1

Siltstone, medium-light-gray, slightly limy; trace of plant debris

Tray 2

Tray 3

Siltstone, similar to above

Siltstone, similar to above; micaceous

Tray 4

Siltstone, medium-light-gray, slightly limy; grades into medium-gray shale; plant debris

Tray 5

Shale, medium-light-gray, slightly limy; calcite fracture fillings; plant debris

Tray 6

Siltstone, medium-light- to light-gray, limy to very limy, dolomitic, "sandy"; many plant fragments. In sharp contact with medium-gray slightly phosphatic silty shale

Cored $25 \mathrm{ft}$., recovered $25 \mathrm{ft}$. (12 trays)

Shale, medium-gray, silty; trace of medium-light-gray

limy siltstone; (reported dip $65^{\circ}-75^{\circ}$ )

Shale, similar to above

Shale, medium-dark-gray, silty, slightly limy and phosphatic; trace of plant debris and microfossils

Shale, similar to above

Shale, as above; interlaminated (may be graded laminae) with medium-light-gray slightly limy siltstone

Tray 5

Shale, medium-dark-gray to dark-brownish-gray, silty, slightly limy and phosphatic, finely micaceous, slightly pyritic

Tray 6

Shale, as above, few siltstone laminae, glauconite, pyrite, questionable burrow fillings

Tray 7
Tray 8

Tray 7
Tray 8

Shale, medium-dark-gray to dark-brownish-gray, silty, slightly limy and phosphatic. Samples in water display abundant silt, glauconite, Foraminifera, mica, pyrite, and burrow fillings

Shale, similar to above; very silty in part

Siltstone, medium-gray to olive-gray, slightly limy, phosphatic, glauconitic; trace of shale as above

Siltstone, light- to medium-light-gray, slightly limy, phosphatic; grades into and interlaminated (may be graded laminae) with medium-dark-gray phosphatic slightly glauconitic silty shale

Tray 1

Tray 2

Tray 3

Tray 4

Well cuttings. Siltstone and shale, as above. Dirty samples

Tray 9

Tray 10

Tray 11

Cored $49 \mathrm{ft}$., recovered $45 \mathrm{ft}$. No samples available

$12,271-12,322$

$12,322-12,371$

Reported description:

12,322-12,326 Sandstone, "dirty" gray, fine-

grained, very silty, well cemented, hard;

interbedded with hard limy dark-gray siltstone; 


\section{Miocene Series-Continued}

Temblor Formation-Continued

Santos Shale Member-Continued

irregular streaks and laminae of silty dark-

brown shale in lower $1 \mathrm{ft}$.

12,326-12,367 Shale, dark-brown to grayish-

brown, silty, hard, massive; irregular streaks,

laminae, and inclusions of "dirty" gray

sandstone and dark-gray limy siltstone as

above; few fine pyrite veins and clusters;

scattered large plant fragments; $\operatorname{dip} 60^{\circ}-65^{\circ}$.

12,367-12,371 Lost.

Well cuttings. Shale and siltstone, as above

$12,371-12,380$

Drilled, no samples

$12,380-12,430$

Well cuttings. Siltstone, medium-light-gray, slightly

limy, very finely sandy in part; 30 percent medium-

dark-gray phosphatic silty shale

$12,430-12,549$

Cored $7 \mathrm{ft}$., no recovery

$12,549-12,556$

Well cuttings. Siltstone and shale, as above. Dirty samples

Cored $4 \mathrm{ft}$., recovered $1 \frac{1}{2} \mathrm{ft}$. No samples available

12,556-12,597

$12,597-12,601$

Description reported:

12,597-12,5981/2 Shale, dark-brown, silty, silicious, hard, partly fractured; rare small

fragments; dip $50^{\circ}-60^{\circ}$.

$12,5981 / 2-12,601$ Lost.

Well cuttings. Shale, as above; unwashed samples

Oligocene Series:

Temblor Formation-Continued

Santos Shale Member-Continued

Shale, medium-dark-gray, slightly limy to limy, phosphatic. Mostly unwashed samples

$12,620-12,696$

Cored $7 \mathrm{ft}$., recovered $7 \mathrm{ft}$. No samples available

Description reported:

12,696-12,703 Shale, brown, silty, hard, massive, micaceous; common small plant fragments; dip about $45^{\circ}$.

Well cuttings. Shale, medium-dark-gray, slightly limy; slickensides; medium-gray very silty dolomite

Drilled, no samples

Cored $10 \mathrm{ft}$., recovered $10 \mathrm{ft}$. No samples available $12,760-12,789$

$12,789-12,799$

Description reported:

12,789-12,799 Shale, dark-brown, silty, hard, massive; abundant plant fragments; dip $35^{\circ}-40^{\circ}$.

Well cuttings. Shale, medium-dark-gray, phosphatic; slickensides. Unwashed samples

Total depth: Driller 


\section{INDEX}

[Italic page numbers indicate major references]

A Page

Agua Sandstone Member $10,11,12,16$ Acknowledgments

Ammobaculites sp 19,39

Ammodiscus sp

Anomalina californiensis

sp

Antelope Shale

13,19

13

.. 34,38

B

Barren shale member, Temblor Formation

Bathysiphon sp

$13,19,37,38$

Beck, R. S., cited

Bentonite ...................... 15, 17, 20, 21, 33, 35, 36

Bitterwater Creek area .......................... 19, 26

Bolivina marginata

marginata adelaidana ............................. 13

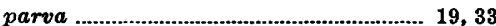

salinasensis ............................................. 19

vaughani .......................................... 19, 38

sp ..................................................... 36

Bone fossils

Bulimina carnerosensis

$13,15,16$

inflata alligata

ovata

13,19

sp ...

$13,19,32$

Buliminella subfusiformis silt zone

$13,19,32$

Burrow, James, cited

Button bed member

Buttonbed Sandstone Member

10,26

\section{C}

Canara (Carneros) Springs

$7,9,10,11$

Carman Sandstone Member

Calitroleum sand zone

Gusher sand zone

Mulinia sand zone

Wilhelm sand zone

Carmel area

43

30

6

Dentalina multilineata

obliqua

pauperata

quadrulata

sp

neros Sandstone Member-Continued upper Shale-Continued

well 555-30R

Carter, R. D., cited 17,21

gareta

19,33

Chico Martinez Creek area ....... 9, 10, 26, 28, 29,

mericanus ................................. 13, 26

floridanus ........................................... 13, 19

hodgei ....................................................... 13

pseudouvigerianus evolutus .............. 13, 19

sp .......................................................... 13

Clavulina communis ................................... 13

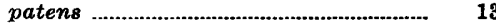

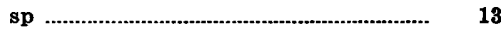

Coal .................................................................... 41

Coalinga area ..................................... 7, 9, 27, 40

Coaly fragments .................................... 15, 36, 41

Coscinodiscus sp ............................... 36, 38, 39, 41

Cuyama Valley ............................................ 27

Cyclammina cancellata obesa .................... 13, 19

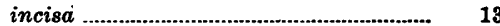

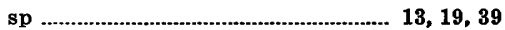

Cymric oil field .......................................... 10

Cymric Shale Member, Temblor

Formation

10

D

Devilwater Creek ..... 31

Devilwater Shale Member ........................... 30, s1

dip ........................................................... 31

well 526-30R ........................................... 31, 32

Devilwater Silt ....................................... 28, 31

Diatomaceous shale ...................................... 27, 28

Diatomaceous siltstone ........................... 37, 38, 39

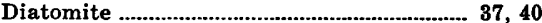

Diatoms ....................................... 17, 36, 37, 38, 41

Dibblee, T. W., Jr., cited ...................... 6, 10, 11

Discorbis sp .............................................. 13

Drilling data ................................................ 2

$\mathbf{E}$

Echinoid spines

Elk Hills area
Third Carneros Sand ............................ 17, 20
upper shale ......................................... 23, 24

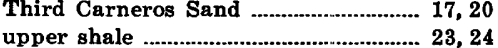

age .................................................... 24

well 526-30R .................................... 24

well 555-30R
$6,7,12,32,34,42$ 
Page

Media Shale Member

dip

stratigraphy

well 526-30R

well 555-30R

Merychippus zone

Methods of investigation

Middle Temblor Shale Member,

Temblor Formation

Miocene rocks

Mollusks

$10,19,25$

Monterey, group name

Monterey Formation

Monterey Group

Monterey series

Monterey Shale

Antelope Shale Member

Belridge Diatomite Member

$2,7,27,39,40$

Brown shale

Chico Martinez (Belridge) Diatomite

Chico Martinez Chert Member

Devilwater Shale Member

28,29

Devilwater Silt

$29,30,31$

Elk Hills Shale Member

Gould Shale Member

28,31

McDonald Shale Member

$23,24,28,29$

McLure Shale Member

$28,29,32,35$

$N$ horizon

$29,31,34,40$

Reef Ridge Shale

34,40

reference section

2,29

Stevens zone

type locality well 526-30R

Mud pectens $\mathbf{R}$

30

31,32

Mya sand zone, San Joaquin Formation ..

$\mathbf{N}$

Naval Petroleum Reserve No. 1

Nodogenerina advena

sp.

Nodosaria anomala

arundinea

pyrula

soluta.

sp

Nonion affinis

North Belridge oil field

\section{0}

Oil stains

$16,17,22,23,24,26,35,38,41,44$

Olig sand zone

Oligocene rocks

\section{$\mathbf{P}$}

Pecten miguelensis

Pelecypods

Permeability, Carneros Sandstone

$$
\text { Member }
$$

First Carneros sand

Santos Shale Member

Second Carneros sand
Phacoides

Page

Phosphatic beds ......... 12, 15, 16, 17, 21, 23, 24, 26

Plant fossils ............................ 14, 15, 16, 17, 23

Plectofrondicularia californica .................. 13 miocenica ................................................. 13

Pliocene rocks, reference section ................ 42

Porosity, Carneros Sandstone Member .... 23 First Carneros sand ............................. $\quad 24$ Santos Shale Member ........................... 17, 18 Second Carneros sand ............................ 21, 22

Post-Miocene rocks ....................................... 42

Pseudoglandulina conica ............................. 13

Pullenia miocenica .................................... 19, 25

Pulvinulinella gyroidinaformis ................ 32, 33 gyroidinaformis zone ........................... $\quad 32$

\section{Q, R}

Quinqueloculina sp

Radiolaria

13

Railroad Gap oil field ................................... 20

Reef Ridge area .................................... 29, 32, 40

Reef Ridge Shale ..................... 2, 7, 34, 35, 39, 40 age .......................................................40, 41

dip ......................................................... 41

F horizon .............................................. 42

reference section .................................... 2

stratigraphy .................................. 40, 41, 42 well 526-30R .............................. 39, 41, 42

References cited ............................................ 44

Rio Bravo oil field ........................................ $\quad 34$

Robulus simplex ......................................... 13, 19

warmani …_.................................... 13, 19

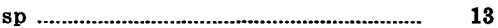

\section{$\mathbf{S}$}

Salinas Shale ................................................ 28

Salinas Valley ........................................ 7, 27, 28

Salt Creek Shale Member ........................... 10

San Joaquin Formation ................................ 43

Mya sand zone ....................................... 43

Scalez sand zone ..................................... 43

well 324-19R .......................................... 43

San Joaquin Geological Society, cited ......... 33

San Joaquin Valley ....... 6, 7, 8, 9, 10, 27, 28, 32

Santa Margarita Formation ........................ 28, 40

Santa Margarita sandstone ......................... 28

Santos Creek ................................................ 11

Santos Shale Member ...................... 10, 11, 19, 20

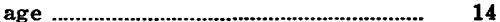

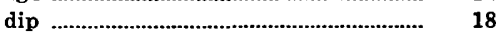

reference section .................................. 12

Saucesian Stage ................... 15, 16, 18, 21, 24, 26

Scalez sand zone ........................................... 43

Second Carneros sand, Carneros Sandstone Member ................. 17, 20, 21, 22, 23

well 526-30R .......................................... 23

well 555-30R …....................................21, 23

Sierra Nevada .................................................. 6

Sigmoilina sp ............................................... 13

Siphogenerina branneri ...................... 19, 25, 26, 31

mayi ................................................. 12, 13 
Well 526-30R-Continued

Media Shale Member, Temblor

Formation

Monterey Shale

Mya sand zone, San Joaquin

Formation

oil sands

Olig sand zone, Etchegoin Formation

post-Miocene rocks

San Joaquin Formation

Santos Shale Member, Temblor

Formation

Scalez sand zone, San Joaquin

Formation

Second Carneros sand, Carneros Sandstone Member

stratigraphy

Third Carneros Sand, Carneros

Sandstone Member

17,20

Tulare Formation

$4,43,44$

Tupman Shale Member, Etchegoin Formation

upper shale, Carneros Sandstone Member

Wygal Sandstone Member, Temblor Formation

Well 532-25Z, Cymric Shale Member, Temblor Formation

lithologic interpretation

Wygal Sandstone Member, Temblor Formation

Well 555-30R, Agua Sandstone Member, Temblor Formation
Well 555-30R-Continued

Page

Carneros Sandstone Member, Temblor Formation

Cymric Shale Member, Temblor Formation

dip

drilling data

First Carneros sand, Carneros

Sandstone Member 3, 21, 23, 24, 25

Gould Shale Member, Monterey Shale $\quad 26$

lithologic log

location

2

Media Shale Member, Temblor Formation

Olig sand zone

Santos Shale Member, Temblor

Formation

$12,17,18$

Second Carneros sand, Carneros Sandstone Member

stratigraphy 17,23

Temblor Formation

3, 10

Third Carneros sand, Carneros Sandstone Member

upper shale, Carneros Sandstone Member

Wygal Sandstone Member, Temblor Formation

Wygal Sandstone Member ........................... 10

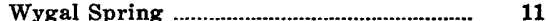

\section{$\mathbf{Z}$}

Zemorra Creek

$10,11,12,16,19,26$

Zemorrian Stage of Kleinpell .......... 9, 10, 11, 12 ,

14,16

U.S. GOVERNMENT PRINTING OFFICE: 1973-515-658/52 
